Aus der Poliklinik für Zahnärztliche Prothetik

(Prof. Dr. med. dent. R. Bürgers)

im Zentrum Zahn-, Mund- und Kieferheilkunde

der Medizinischen Fakultät der Universität Göttingen

\title{
Gewinnung und Charakterisierung von osteoblastären Zellen aus dem humanen Alveolarknochen
}

INAUGURAL-DISSERTATION

zur Erlangung des Doktorgrades für Zahnheilkunde

der Medizinischen Fakultät der

Georg-August-Universität zu Göttingen

vorgelegt von

Diana Dillschneider

aus

Saarlouis

Göttingen 2017 
Dekan:

Prof. Dr. rer. nat. H. K. Kroemer

\section{Betreuungsausschuss}

Betreuer/in

Prof. Dr. med. N. Miosge

Ko-Betreuer/in:

Prof. Dr. med H. Siggelkow

\section{Prüfungskommission}

Referent/in

Prof. Dr. med. N. Miosge

Ko-Referent/in:

Prof. Dr. med H. Siggelkow

Datum der mündlichen Prüfung: 14.05.2018 
Hiermit erkläre ich, die Dissertation mit dem Titel "Gewinnung und Charakterisierung von osteoblastären Zellen aus dem humanen Alveolarknochen" eigenständig angefertigt und keine anderen als die von mir angegebenen Quellen und Hilfsmittel verwendet zu haben.

Göttingen, den. 
Inhaltsverzeichnis

Abbildungsverzeichnis

Tabellenverzeichnis

Abkürzungsverzeichnis

1 Einleitung

1.1 Das Parodont

1.1.1 Die Gingiva

1.1.2 Das parodontale Ligament

1.1.3 Das Zement

1.2 Der Alveolarknochen

1.2.1 Topographie und Struktur

1.2.2 Zusammensetzung

1.2.3 Zelluläre Grundlagen

1.2.4 Die Knochenmatrix

1.2.5 Einfluss von Wachstumsfaktoren und Zytokinen

1.2.6 Unterschiede osteoblastärer Zellen zu anderen Zelltypen

1.3 Aufgabenstellung 15

1.3. Aufgabenstellung 17

2 Material und Methoden 18

$\begin{array}{lll}2.1 & \text { Gewebeproben und Zellgewinnung } & 18\end{array}$

$\begin{array}{lll}2.2 & \text { Zellkultur } & 19\end{array}$

2.3 Osteogene Stimulation 20

2.4 mRNA-Isolation aus primären Zellen 20

2.5 Synthese von cDNA 21

2.6 Polymerase-Kettenreaktion 22

$\begin{array}{lll}2.6 .1 & \text { Allgemeines zur PCR } & 22\end{array}$

2.6.2 Quantitative Echtzeit-PCR 22

$\begin{array}{lll}2.6 .3 & \text { Protokoll der qRT-PCR } & 23\end{array}$

2.6.4 Housekeeping-Gene 24

$\begin{array}{lll}2.6 .5 & \text { Gradienten-PCR } & 25\end{array}$

$\begin{array}{lll}2.6 .6 & \text { Primerdesign } & 25\end{array}$

2.6.7 Statistische Auswertung der Analyse - Pfaffl 27 
$2.7 \quad$ Immunzytochemie 28

2.7.1 Allgemeines zur Immunzytochemie 28

$\begin{array}{lll}2.7 .2 & \text { Versuchsdurchführung } 28\end{array}$

2.7.3 Verwendete Antikörper in der Immunzytochemie 30

2.8 Western Blot 30

2.8.1 Allgemeines zum Western Blot 30

2.8.2 Proteinprobenvorbereitung 31

2.8.3 Natriumdodecylsulfat-Polyacrylamidgelelektrophorese 32

$\begin{array}{lll}2.8 .4 & \text { Versuchsdurchführung } 34\end{array}$

2.8.5 Proteindetektion 35

2.8.6 Immunmarkierung 36

2.8.7 Verwendete Antikörper im Western Blot 37

2.8.8 Auswertung der Western Blots 37

2.8.9 Strippen der PVDF-Membran 38

2.9 Durchflusszytometrie 38

2.9.1 Allgemeines zur Durchflusszytometrie (FACS-Analyse) 38

2.9.2 Versuchsdurchführung 38

2.9.3 Verwendete Antikörper in der FACS-Analyse 39

$\begin{array}{ll}\text { 2.9.4 Auswertung der FACS-Analyse } & 40\end{array}$

3 Ergebnisse 41

3.1 Lichtmikroskopische Bilder osteoblastärer Zellen 42

3.2 Nachweis der Immortalisierung 43

3.3 Quantitative Auswertung der Echtzeit-PCR 44

3.4 Lichtmikroskopische Bilder osteogen differenzierter Zellen 46

3.5 Quantitative Echtzeit-PCR osteogen differenzierter Zellen 47

3.6 Nachweis von Kollagen I im Western Blot 48

3.7 Nachweis von Runx2 im Western Blot 49

3.8 Nachweis von SOX9 im Western Blot 50

3.9 Immunzytochemischer Nachweis verschiedener Matrixproteine 51

3.10 Nachweis verschiedener Marker in der Durchflusszytometrie 56

4 Diskussion $\quad 57$

4.1 Nachweis nicht-kollagener Knochenmatrixproteine 57

4.2 Nachweis von Kollagentyp I und III 61 
4.3 Nachweis der Transkriptionsfaktoren RUNX2 und SOX9 61

$4.4 \quad$ Nachweis von VEGF 64

4.5 Nachweis von CP-23 64

4.6 Nachweis der Proteoglykane Dekorin und Versikan 66

4.7 Nachweis von alkalischer Phosphatase, RANKL und Sclerostin 67

4.8 Klinische Relevanz der Studie 69

5 Zusammenfassung $\quad 71$

$\begin{array}{lll}6 & \text { Literaturverzeichnis } & 73\end{array}$ 
Abbildungsverzeichnis

Abbildung 1: Lichtmikroskopische Übersicht- und Detailaufnahme osteoblastärer Zellen

Abbildung 2: Nachweis der Immortalisierung osteoblastärer Zellen im Agarosegel

Abbildung 3: Quantitative Auswertung des relativen mRNA-Levels der Markerproteine Kollagen I, Kollagen III, SOX9, RUNX2, CP-23

Abbildung 4: Quantitative Auswertung des relativen mRNA-Levels der Markerproteine Dekorin, Versikan, Osteocalcin, BSP, VEGF

Abbildung 5: Lichtmikroskopische Übersicht- und Detailaufnahme osteogen differenzierter Zellen

Abbildung 6: Quantitative Auswertung des relativen mRNA-Levels der Markerproteine CP-23, Osteocalcin und ALP nach osteogener Differenzierung

Abbildung 7: Proteinnachweis von Kollagen I

Abbildung 8: Proteinnachweis von Runx2

Abbildung 9: Proteinnachweis von Sox9

Abbildung 10: Immunzytochemischer Nachweis von Runx2

Abbildung 11: Immunzytochemischer Nachweis von Sox9

Abbildung 12: Immunzytochemischer Nachweis verschiedener Markerproteine 54

Abbildung 13: Immunzytochemischer Nachweis von Kollagen III

Abbildung 14: Quantitative Auswertung der FACS-Analyse 
Tabellenverzeichnis

Tabelle 1: Medium/Nährmedium 19

Tabelle 2: KAPA SYBR Fast qPCR Kit (peqlab) 23

Tabelle 3: Zyklusablauf im Thermocycler (Eppendorf) 24

Tabelle 4: HKG 25

Tabelle 5: qPCR-Primer $\quad 26$

Tabelle 6: Reagenzien 28

Tabelle 7: Immunzytochemie: primäre Antikörper 30

Tabelle 8: Immunzytochemie: sekundäre Antikörper 30

Tabelle 9: Trenngel (für 2 Gele) 33

Tabelle 10: Sammelgel (für 2 Gele) 34

Tabelle 11: Western Blot: primäre Antikörper 37

Tabelle 12: Western Blot: sekundäre Antikörper 37

Tabelle 13: Antikörper der Ladungskontrolle 37

Tabelle 14: FACS-Analyse: primäre Antikörper 39

Tabelle 15: FACS-Analyse: sekundäre Antikörper 39 
Abkürzungsverzeichnis

AK

ALP

BMP

BSP

CPC

CT-Wert

DG

DMEM

GAG

HMG-Box

HKG

MMP

OB

ON

OPN

OPG

PDL

PG

PVDF-Membran

qRT-PCR
Antikörper

alkalische Phosphatase

bone morphogenic protein

bone sialoprotein

chondrogene Progenitorzellen

cycle threshold

Deckgläschen

Dulbecco`s Modified Eagle`s Medium

Glykosaminoglykan

high mobility group

Housekeeping-Gen

Matrixmetalloproteinase

Osteoblast

Osteonectin

Osteopontin

Osteoprotegerin

parodontales Ligament

Proteoglykan

Polyvinylidenfluorid-Membran

quantitative real-time PCR 
SIBLING

SLRP

SPARC

Tgf $\beta$

VEGF

ZB small integrin-binding ligand $\mathrm{N}$-linked glycoproteins

small leucin-rich proteoglycan

secreted protein acidic and rich in cysteine

tumor negrosis growth factor $-\beta$

vascular endothelial growth factor

Zementoblast 


\section{Einleitung}

In der folgenden Einleitung werden zunächst die Komponenten des Zahnhalteapparates beschrieben, insbesondere des Alveolarknochens, aus dem die in dieser Arbeit charakterisierten osteoblastären Zellen stammen. Des Weiteren wird auf die Differenzierung von osteogenen Progenitorzellen zu Präosteoblasten und Osteoblasten und deren Funktion eingegangen. Unterschiedliche Bestandteile der Knochenmatrix werden herausgearbeitet, und der heutige Kenntnisstand bezüglich dieser Zellgruppe wird erläutert.

\subsection{Das Parodont}

Der Zahnhalteapparat oder Parodontium ( $p a r=$ um, herum; odontos $=$ der Zahn) ist eine funktionelle Einheit, deren Hauptaufgabe in der Verankerung des Zahnes im Knochen sowie der Abwehr äußerer Noxen besteht. Zusätzlich sollen Kaukräfte gedämpft und das Mundhöhlenmilieu von der Zahnwurzel getrennt werden (Hellwig et al. 2010). Seine Hauptkomponenten werden aus vier Bestandteilen gebildet: der Gingiva, dem Zement, dem Alveolarknochen und dem parodontalen Ligament (PDL) (Bartold et al. 2000). Hierbei ist es wichtig zu verstehen, dass jede dieser Strukturen über unterschiedliche Charakteristika und Zusammensetzung verfügt, wobei eine korrekte Funktion des Parodontiums nur gegeben ist, wenn alle Bestandteile funktionell zusammenarbeiten (Nanci und Bosshardt 2006).

\subsubsection{Die Gingiva}

Die Gingiva wird der mastikatorischen Mukosa zugeordnet und geht an der Mukogingivallinie (Linea girlandiformis) in die auskleidende Mukosa über (Hellwig et al. 2010). Der befestigte Teil der Gingiva verläuft koronal der Linea girlandiformis zur gingivalen Furche und ist mit dem Periost des Alveolarkamms verbunden (Hassell 1993). Charakteristisch ist eine oberflächlich sichtbare Stippelung, was im gesunden Zustand erkennbar sein sollte (Bergström 1984). Die freie marginale Gingiva ist bis zu 1,5 mm breit und liegt oberhalb der gingivalen Furche unbefestigt jedem Zahn kranzförmig an (Orban 1948). Der approximale Raum zwischen zwei Zähnen wird 
durch das sogenannte Col, eine Verschmelzung aus zwei benachbarten Saumepithelien, aufgefüllt.

Mikroskopisch lassen sich das Saumepithel, das orale Sulkusepithel und das orale Epithel voneinander unterscheiden (Hellwig et al. 2010).

Das orale Gingivaepithel wird von apikal nach koronal in vier Schichten eingeteilt, welche sich durch unterschiedliche Zellarten voneinander abgrenzen lassen und dessen oberste Schicht verhornt (Bartold et al. 2000). Unter dem oralen Sulkusepithel versteht man den Bereich zwischen dem Saumepithel und dem oberen Rand der freien Gingiva, welcher die äußere Wand des Sulkus bildet, allerdings keine durchgängig verhornte Oberflächenschicht mehr aufweist.

Das unverhornte Saumepithel bildet den Boden des oralen Sulkus und verbindet die Zahnhartsubstanzoberfläche durch Hemidesmosomen mit dem Epithel (Hassell 1993).

\subsubsection{Das parodontale Ligament}

Als parodontales Ligament wird das Weichgewebe bezeichnet, dass ein Netzwerk aus verschieden laufenden Fasern zwischen der Innenwand eines Alveolarfaches und der Zahnwurzel bildet. Seine Funktion liegt in der Verankerung und Unterstützung des Zahnes in seinem Knochenfach sowie dem Schutz und der sensorischen Wahrnehmung bei der Mastikation (Beertsen et al. 1997). Es dient außerdem als Zellreservoir für die Gewebehomöostase und Regeneration (Nanci und Bosshardt 2006). Einige Fasern erstrecken sich vom Zahn zur Gingiva oder dem Periost des Alveolarknochens, zirkulär, interdental oder vom Periost zum Zahnfleisch. Auch semizirkuläre oder transgingivale Fasern sind zu finden (Hassell 1993).

Die Breite des parodontalen Ligaments kann zwischen 0,15 und 0,38 mm variieren, wobei sie mit steigendem Alter abzunehmen scheint (Nanci und Bosshardt 2006).

Im Bindegewebe des PDL wird sowohl ein zellulärer als auch extrazellulärer Anteil gefunden, bekannt als extrazelluläre Matrix (EZM). Zellen, die in diesem Bindegewebe vorkommen, sind Fibroblasten, Mallassez`sche Epithelreste, Osteoblasten und -klasten, Zementoblasten, Monozyten sowie Makrophagen, Odontoblasten und undifferenzierte Mesenchymzellen. Der extrazelluläre Anteil besteht hauptsächlich 
aus Kollagenfaserbündeln, die in eine gallertige Grundsubstanz eingebettet sind (Nanci und Bosshardt 2006).

Die Hauptfasern des PDL sind Kollagenfasern vom Typ I und III, daneben auch Kollagen V, VI, XII, welche sich zu Bündeln zusammenlagern (Beertsen et al. 1997). Die teilweise oder vollständig mineralisierten Enden dieser Faserbündel sind in das Wurzelzement oder den Alveolarknochen eingebettet und werden dann als Sharpeysche Fasern bezeichnet (Nanci und Bosshardt 2006).

Elastische Fasern, die Oxytalanfasern, scheinen Blut- und Lymphgefäße zu unterstützen und verlaufen vertikal entlang der Zahnhartsubstanzoberfläche, meist in den Zement inserierend, jedoch selten in den Alveolarknochen. Die Dehnung der Fasern als Reaktion auf verschiedene Spannungen kann vom Gefäßsystem wahrgenommen werden (Fullmer et al. 1974; Nanci und Bosshardt 2006).

Außer den genannten Fasern enthält die EZM des Parodontalligaments eine Anzahl an Proteoglykanen (PG). Diese Makromoleküle befinden sich an der Zelloberfläche und regulieren die Zelladhäsion, das Wachstum, die Komplexbildung und sind in der Lage, Wachstumsfaktoren zu binden. Proteoglykane bestehen aus einem zentralen Proteinfaden (core protein), dessen Größe von 11 kDa bis 400 kDa variieren kann, und an den bis zu 100 Glykosaminoglykane gebunden sein können. Es sind vier Glykosaminoglykan-Gruppen zu unterscheiden: Heparin / Heparan-Sulfate,

Chondroitin-Sulfate / Dermatan-Sulfate, Keratan-Sulfat und Hyaluronsäure, welche jeweils aus einer Mehrzahl an Disacchariden bestehen. Glykosaminoglykane sind in der Lage, eine große Menge an Wasser zu binden und stellen ein extrazelluläres Wassermilieu bereit. Dekorin, Versikan, Biglykan und CD 44 sind die im Parodontalligament vorkommenden PG`s (Ruoslahti 1988; Häkkinen et al. 1993).

\subsubsection{Das Zement}

Das Wurzeldentin wird von einer 50-200 $\mu \mathrm{m}$ dicken Schicht nicht vaskularisierten Zements ummantelt, welches dazu dient, Fasern des parodontalen Ligaments aufzunehmen und den Zahn in seiner Alveole zu verankern (Hassell 1993; Nanci und 
Bosshardt 2006). Das Zement besteht zu jeweils 50 \% aus anorganischer und organischer Matrix, wobei der Großteil der anorganischen Matrix aus Hydroxylapatit und $90 \%$ des organischen Teils aus Kollagen I und III besteht. Kollagen Typ XII sowie Spuren von Kollagen V, VI, XIV sind ebenfalls im Zement zu finden (Bartold und Narayanan 2006; Nanci und Bosshardt 2006).

Vier unterschiedliche Zement-Typen lassen sich in ihrer Zusammensetzung und Lokalisation unterscheiden: Das azelluläre, afibrilläre Zement, das azelluläre Fremdfaserzemt, das zelluläre Eigenfaserzement sowie Gemischtfaserzement aus azellulären Fremd- und zellulären Eigenfasern (Hassell 1993; Bosshardt und Selvig 1997). Abgesehen von den unterschiedlichen Faserarten lassen sich eine Vielzahl von PG`s finden, die als Versikan, Dekorin, Biglycan, Fibromodulin und Lumican identifiziert werden können. Zusätzlich sind in der EZM des Zements Bone Sialoprotein (BSP), Tenascin, Osteopontin (OPN), Fibronectin und Osteonectin (ON) zu finden (Bartold und Narayanan 2006).

\subsection{Der Alveolarknochen}

Der Alveolarknochen stellt die letzte Komponente des Parodontiums dar und wird im Folgenden beschrieben. Dabei wird auf die Einordnung und Funktion des Alveolarknochens innerhalb der beiden Kiefer eingegangen und bestimmte Besonderheiten herausgearbeitet.

\subsubsection{Topographie und Struktur}

Die Mandibula und die Maxilla eines erwachsenen Menschen lassen sich in mehrere bezüglich ihrer Struktur und Funktion zu unterscheidende Bereiche aufteilen. Der untere Teil der Kiefer wird von dem zahntragenden oberen Teil abgegrenzt, welcher als Alveolarfortsatz bezeichnet wird. Er besteht aus drei verschiedenen Anteilen: der Kortikalis, der Spongiosa und dem Alveolarknochen (Radlanski 2011).

Die Kortikalis (cortical bone) stellt vestibulär und palatinal bzw. lingual eine unterschiedlich dicke kompakte Knochenplatte dar und wird von einer Periostschicht überzogen (Radlanski 2011). Sie besitzt eine oberflächliche Schicht feinfaserigen 
Knochens, der von einem Havers-Kanal-System unterstützt wird (Nanci und Bosshardt 2006).

Der spongiöse Knochen (cancellous bone) befindet sich zwischen den beiden Kortikalisplatten und ist aus netzartig angelegten dünnen Knochentrabekeln aufgebaut. In den Zwischenräumen dieser Bälkchen befindet sich Knochenmark, einige größere Trabekel beherbergen ebenfalls Harvers-Kanäle (Nanci und Bosshardt 2006; Radlanski 2011). In den Kieferwinkeln und der Region des Tuber maxillae lässt sich außerdem beim Erwachsenen rotes, blutbildendes Knochenmark finden (Schroeder 1986). Um sämtliche Druck- und Zugkräfte abzufangen, sind die Trabekel in sogenannten Trajektorien angeordnet. Dies sind Linien entlang derer die einwirkenden Kräfte weitergeleitet werden (Seipel 1948). An einigen Stellen innerhalb der Kieferknochen kommt die Spongiosa allerdings nur geringfügig bzw. manchmal auch überhaupt nicht vor (Saffar et al. 1997).

Die dritte Komponente der Alveolarfortsätze, der Alveolarknochen, ist eine 0,1 bis 0,4 mm dicke Schicht, welche die gesamte Zahnalveole auskleidet und die Zahnwurzeln unterstützt. Er neigt zu ständigen Remodellierungsprozessen als Folge der Zahnentwicklung und des Kauakts (Cho und Garant 2000; Sodek und McKee 2000). Dieser Teil des Knochens ist gekennzeichnet durch unterschiedlich verlaufende Kollagenfasern. Einige dieser Fasern werden von Fibroblasten des PDL gebildet und strahlen als Sharpey sche Fasern von extern in den Knochen ein, um anschließend senkrecht parallel zu dessen Oberfläche entlang zu verlaufen. Nach ihrem Eintritt in den Knochen mineralisieren die Fasern, wobei ihr Inneres weiterhin hypomineralisiert bleibt. Den zweiten Faseranteil stellen die von Osteoblasten gebildeten Kollagenfasern dar, die weniger dicht und unregelmäßig verlaufen. Durch diese besondere Struktur wird der Alveolarknochen auch als Bündelknochen bezeichnet (Saffar et al. 1997). Sogenannte Volkmann-Kanäle ziehen ebenfalls durch den Alveolarknochen hindurch und mit ihnen Nerven-, sowie Blut- und Lymphgefäße, welche so aus dem Knocheninneren in den Parodontalspalt gelangen (Birn 1966). 
Im Laufe des Zahnwachstums oder der Remodellierungsprozesse kommt es auf einer Seite der Alveole zu appositionellen und auf der anderen Seite zu resorbierenden Vorgängen. Auf der Resorptionsseite sind oberflächlich eine Vielzahl unterschiedlich tiefer und breiter unregelmäßig verlaufender Lakunen sichtbar, wohingegen die Appositionsseite gleichmäßig erscheint (Saffar et al. 1997). Der Übergang des Alveolarknochens zur Kortikalis, auch als Lamina cribriformis benannt, erfolgt an einer dünnen zirkulären Knochenkante, dem Limbus alveolaris (Radlanski 2011).

\subsubsection{Zusammensetzung}

Der menschliche Knochen besteht durchschnittlich aus 66-70 \% anorganischem Material und zu 22-33 \% aus organischen Bestandteilen. Die restlichen ca. $8 \%$ sind Wasser. Über 90 \% des organischen Anteils besteht aus Kollagentyp I, der Rest aus nicht-kollagenen Proteinen. Hydroxylapatit macht $60 \%$ des anorganischen Materials aus, der Rest besteht aus amorphem Kalziumphosphat (Quelch et al. 1983)

\subsubsection{Zelluläre Grundlagen}

Die Schädel- und Kieferknochen bildenden Zellen sind während der Embryogenese migriert und stammen primär aus der Neuralleiste (Ten Cate und Mills 1972).

Für die lebenslang erfolgende Differenzierung zu Knochenzellen dienen undifferenzierte Mesenchymzellen aus dem Knochenmark, welche durch verschiedene Signalmoleküle, unter anderem Transforming growth factor- $\beta$ (Tgf- $\beta$ ) und Bone morphogenetic protein (BMP) zur Proliferation angeregt werden können. Aus ihnen können sowohl Osteoprogenitorzellen als auch Präosteoblasten entstehen (Long et al. 1995). Präosteoblasten entstehen aus der Differenzierung von Mesenchymzellen aus dem Knochenmark (Ducy et al. 2000b). Runx2 (früher Cbfa-1) scheint an der Aktivierung dieser Kaskade maßgeblich beteiligt zu sein und ist über den gesamten Differenzierungszeitraum nachzuweisen. Außerdem scheint Runx2 die Expression mehrerer Gene in Osteoblasten und Präosteoblasten zu steuern, darunter Osteocalcin, Osteopontin, Bone Sialoprotein und Kollagen I-Vorgänger. Die Aktivität dieses Gens ist eindeutig eingeleitet durch Bmp-7 und wird von Vitamin D3 gehemmt 
(Ducy et al. 1997). Charakteristisch für diese Zellgruppe scheint momentan eindeutig der Nachweis des Enzyms alkalische Phosphatase (ALP) zu sein, welches entlang der Zellmembran aktiv ist (Owen 1980; Pinero et al. 1995).

Die Osteoblasten liegen meist dicht aneinander oder sogar geschichtet auf der Oberfläche des Alveolarknochens und stehen miteinander durch sogenannte gap junctions und zytoplasmatische Ausläufer in Verbindung, die außerdem weit in das von ihnen produzierte Osteoid hineinreichen. Dabei befindet sich ihr sekretorisches Ende stets auf der von ihnen produzierten Matrixoberfläche (Dudley und Spiro 1961; Radlanski 2011). Das Netz, was diese Zellen formen, ist dreidimensional betrachtet perforiert, da kontinuierlich remodellierte Fasern des Parodontalligamentes eingebettet werden müssen (Kurihara und Enlow 1980). Das Zytoplasma der Zellen zeichnet sich durch ein raues endoplasmatisches Retikulum sowie einen gut ausgebildeten Golgi-Apparat und sekretorische Vesikel aus (Dudley und Spiro 1961). Ebenso wie Präosteoblasten sind diese Zellen mesenchymalen Ursprungs durch die Expression des Enzyms ALP zu erkennen, welches der erste morphologische Indikator für eine osteoblastäre Differenzierung zu sein scheint und erhöht direkt vor der Osteoidproduktion und Mineralisierung exprimiert wird (Ashton et al. 1980; Zernik et al. 1990) Die Hauptaufgabe der alkalischen Phosphatase liegt wahrscheinlich in der Mineralisierung der Knochenmatrix. In Untersuchungen mit ALP -/- Mäusen konnte nachgewiesen werden, dass sich Osteoblasten zwar vollständig differenzieren und die Bildung von Osteoid uneingeschränkt verläuft, allerdings keine Mineralisierungsprozesse ablaufen (Wennberg et al. 2000). Ein Zusammenhang zwischen Mutationen des Gens der alkalischen Phosphatase und erniedrigter Serumaktivität mit Formen der Hypophosphatasie, einer Knochenstoffwechselstörung, konnte ebenfalls festgestellt werden. Diese Krankheit kann sich unterschiedlich äußern, von Stillgeburten ohne radiologische Knochenveränderungen bis hin zu Frakturen im Erwachsenenalter (Henthorn et al. 1992). Als einzige Osteoblast-spezifische Marker wurden Codierungen für Runx2 und Osteocalcin gefunden (Ducy et al. 2000b). Die Hauptaufgabe der Osteoblasten besteht in der Sekretion unmineralisierter Kollagen I-reicher Knochenmatrix sowie des vascular endothelial growth factors (VEGF), welcher für die Bildung neuer Blutgefäße verantwortlich ist und damit direkt mit der Bildung und Reparatur des Knochens in Verbindung steht (Harada et al. 1995; Radlanski 2011). Vegf gehört zu einer großen Protein-Familie, wobei se- 
chs Isoformen bekannt sind und induziert durch die Bindung an die TyrosinkinaseRezeptoren VEGFR-1, -2 und -3 seine Signale auf das Endothel (Ylä-Herttuala et al. 2007). Es wurde allerdings auch nachgewiesen, dass Osteoblasten dazu in der Lage sind, Kollagenasen zu sezernieren und damit die oberflächliche Osteoidschicht der Knochen zu entfernen (Pierce et al. 1991). Außerdem scheinen sie eine Rolle bei der Differenzierung ihrer Gegenspieler, den knochenabbauenden Osteoklasten zu spielen. Ihr transmembraner Ligand RANKL bindet an seinen Rezeptor, RANK, welcher sich in osteoklastären Vorläuferzellen befindet und aktiviert damit deren Entwicklung zu ausgereiften Osteoklasten. Osteoprotegerin (OPG), ebenfalls von Osteoblasten produziert, kann diese Reaktion verhindern, indem es an RANKL bindet und den Liganden damit blockiert (Hofbauer und Schoppet 2004; Al-Fakhri et al. 2005). Die Liganden sowie OPG sind Mitglieder der TNF-Superfamilie (Aubin und Bonnelye 2000). Mit Hilfe der sogenannten Kalziumpumpe innerhalb der Zellen sind diese außerdem dazu in der Lage, Kalzium in den Extrazellulärraum zu transportieren, entgegen aller Vermutungen nicht um die sezernierte Matrix zu mineralisieren, sondern wahrscheinlich, um Kalzium aus dem Knochen heraus zu bewegen (Abramowitz und Suki 1996). Die Differenzierung zu Osteoblasten erfolgt aus mesenchymalen Stammzellen, welche sich in unterschiedliche Zelllinien differenzieren können (Owen 1980).

Osteozyten sind Zellen, welche umgeben von perilakunärer Matrix in Knochenlakunen liegen und viele lange Zellfortsätze besitzen, die in Knochenkanälchen fortlaufend in Kontakt mit benachbarten Osteozyten sowie Osteoblasten und bone lining cells stehen (Dudley und Spiro 1961; Sodek und McKee 2000). Dieses Kanalsystem ist aufgefüllt mit bone fluid und ist in seiner ganzen Weite als Syntizium zu betrachten, wodurch diese Zellen ausgesprochen gute mechanosensorische Fähigkeiten besitzen und die Notwendigkeit zum Knochenauf- und -abbau erkennen. Durch Kräfte produzierte Flüssigkeitsschwankungen und Unregelmäßigkeiten im Hormonhaushalt können ebenfalls wahrgenommen werden (Manolagas 2000; Komori 2002). Es wird außerdem angenommen, dass mit Hilfe dieses Systems Kalzium durch den gesamten Knochen transportiert werden kann (Drenckhahn et al. 2003). Schon lange ist in der Literatur beschrieben, dass diese Zellart von den Osteoblasten abstammt, wobei das genaue Schema der Umwandlung nicht bekannt ist. Unterschiedliche Theorien gehen davon aus, dass Osteoblasten ungeordnet auf der 
Knochenmatrix verweilen und Osteoid produzieren, wobei die tieferen Zellschichten in dieser Matrix eingemauert werden. Andere gehen davon aus, dass einige Osteoblasten kontrolliert mit der Osteoidproduktion stoppen und sich einbetten lassen. Da sich die meisten Forschungen mit Osteoblasten- und klasten beschäftigen, wird diese Zellart vernachlässigt und ist daher schlechter erforscht, obwohl sie insgesamt 95 \% aller Knochenzellen darstellen (Franz-Odendaal et al. 2006). Als bone lining cells werden Zellen bezeichnet, die oft weniger als $0,1 \mu \mathrm{m}$ dick sind und flach der inaktiven Knochenoberfläche anliegen. Oft sind gap junctions zwischen benachbarten Knochensaumzellen sowie zu Osteozyten zu sehen (Miller und Jee 1987).

Eine Aussage zu ihrer Funktion ist bis heute schwierig, es wird ihnen allerdings eine knochenschützende Aufgabe zugeschrieben (Drenckhahn et al. 2003).

\subsubsection{Die Knochenmatrix}

Die im Folgenden beschriebene strukturelle Zusammensetzung des Knochens bezieht sich auf die bisher in der Literatur erläuterten Erkenntnisse, gewonnen aus Forschungen an unterschiedlichen Knochengeweben. Bis zum jetzigen Zeitpunkt sind keinerlei Experimente am humanen Alveolarknochen durchgeführt worden, um dessen Zusammensetzung zu erforschen und eventuelle Gemeinsamkeiten sowie Unterschiede zu bereits gewonnenen Ergebnissen herauszuarbeiten.

Die von Osteoblasten im humanen als auch tierischen Organismus sezernierte Knochenmatrix besteht zu $80-90 \%$ aus unterschiedlichen Kollagentypen und zu $10 \%$ aus nicht-kollagenen Proteinen. Hierzu zählen Osteocalcin, Osteopontin sowie Osteonectin, Bone Sialoprotein und die kleinen Proteogylkane Dekorin, Biglykan und Versikan. Einige Wachstumsfaktoren, Chemokine und Matrixmetalloproteine gehören ebenfalls dazu (Sodek und McKee 2000; Drenckhahn et al. 2003). Diese zunächst unmineralisierte Matrix wird als Osteoid bezeichnet und im Laufe eines Reifungsprozesses zu vollständig mineralisiertem Knochen umgewandelt (Schroeder 1986).

Unterschiedliche Kollagentypen bilden gemeinsam ein komplexes Fasersystem aus, welches dem Knochen seine große Stabilität verleiht. Mehr als 95 \% der Fasern 
stammen vom Kollagentyp I, die restlichen hauptsächlich von Kollagentyp V (Rao et al. 1979; Lukinmaa und Waltimo 1992). Einige Fasern von Typ III strahlen zusammen mit Typ I-Fasern als Sharpey`sche Fasern von extern in den Knochen ein und bilden so eine stabile Verbindung zwischen Alveole und Zahn aus (Wang et al. 1980). Moderate Nachweise von Kollagentyp XII und VI sind ebenfalls erbracht (Karimbux et al. 1992; Lukinmaa und Waltimo 1992).

Alle Fasertypen zusammen bilden ein komplexes System aus, welches über zwischenmolekulare Vernetzungen stabilisiert wird, wobei unklar ist, wie die Osteoblasten diese Zusammensetzung kontrollieren (Eyre et al. 1988; Radlanski 2011). Kleine plättchenähnliche Kristalle aus Hydroxylapatit $\left(\mathrm{Ca}_{10}\left[\mathrm{PO}_{4}\right]_{6}[\mathrm{OH}]_{2}\right)$ finden sich zwischen diesem Gerüst aus verwundenen Kollagenfasern (Sodek und McKee 2000).

Osteocalcin, auch bekannt als bone gamma-carboxyglutamic acid-containing protein, ist ein kleines $5.8 \mathrm{kDa}$ Protein, dass bis zu $15 \%$ der nicht-kollagenen Matrixproteine ausmacht und auf Chromosom 1 lokalisiert ist. Es wird Vitamin-K-abhängig aktiviert, wobei zwei Glutaminsäuren zu $\gamma$-Carboxyglutaminsäure carboxyliert werden (Bronckers et al. 1994; Sodek und McKee 2000). Osteocalcin hat eine hohe Affinität zu anorganischem Knochenmaterial, kann Kalzium-lonen sehr gut binden sowie transportieren und scheint die Mineralisation des Knochens negativ zu beeinflussen. In Osteocalcin-knock-out-Mäusen und unter dem Einsatz von Vitamin-KAntagonisten konnte eine gesteigerte Knochenmasse und Funktionalität nachgewiesen werden (Price und Williamson 1981; Ducy et al. 1996; Sodek und McKee 2000). Beeinflusst durch das Hormon $1,25(\mathrm{OH})_{2} \mathrm{D}_{3}$ (Calcitirol) wird vermindert Osteocalcin exprimiert, aufgrund der verringerten Bindung von Runx2 an OSE2 (Zhang et al. 1997).

OSE2, ein Osteoblast-spezifisches Cis-Element, konnte in dem Promotergen für Osteocalcin gefunden werden. Weitere Gene, in denen OSE2 präsent ist, sind Osteopontin, Bone Sialoprotein und $\alpha 1(\mathrm{I})$ Kollagen. Runx2 ist das Protein, welches an OSE2 bindet und die Gen-Expression dieser Proteine auslöst. Die Expression von Runx2 ist strikt an die Zellen der osteoblästaren Linie gebunden und während der gesamten Differenzierung der undifferenzierten Mesenchymzellen zu vollständig entwickelten Osteoblasten nachweisbar, unabhängig von dem embryologischen Ur- 
sprung des Knochens. Als osteoblastärer Transkriptionsfaktor ist Runx2 an der Regulation dieser Weiterentwicklung beteiligt, ein Mangel dieses Proteins in Mäusen führte zu einer fehlenden Osteoblastenbildung. Die Tiere starben direkt nach der Geburt, da sie unfähig waren zu atmen (Ducy et al. 1997; Komori et al. 1997; Ducy et al. 2000b).

Runx2 gehört zur Runx-Familie, von der drei Gene identifiziert wurden. Das für die Codierung dieses Proteins zuständige Gen ist das Runx2-Gen (Cbfa1-Gen), eines der 3 bekannten Homologe von dem Drosophila Runt-Gen (Ogawa et al. 1993; Komori und Kishimoto 1998). Die glutamin- und alaninreiche Runt-Domäne befindet sich an seinem N-terminale Ende. Eine Regulation von Runx2 durch BMP7 und Calcitirol konnte festgestellt werden, indem Fibroblasten unter Einsatz von BMP7 dazu angeregt wurden Runx2 zu exprimieren, obwohl diese unter normalen Umstanden keine Osteoblast-spezifischen Proteine produzieren und die Bindung zu OSE2 durch Vitamin $D_{3}$ verhindert werden konnte (Ducy et al. 1997; Zhang et al. 1997) Mutationen des Cbfa1-Gens spielen außerdem bei der Entwicklung skelettaler Krankheiten eine Rolle und sind bei dem Krankheitsbild der kleidokranialen Dysplasie zu finden (Mundlos et al. 1997). Runx2 fördert die Expression von RANKL und inhibiert OPG, sodass eine Osteoklasten fördernde Funktion nachzuweisen ist (Komori 2002)

Osteopontin und Bone Sialoprotein, urspünglich als Sialoprotein I und II aus mineralisierter Knochenmatrix isoliert und charakterisiert, teilen einige strukturelle Gemeinsamkeiten sowie Unterschiede (Franzén und Heinegård 1985). Beide 34 kDa großen Proteine sind auf Chromosom 4 codiert. Die Glutaminsäureester im BSP und Asparaginsäureester in OPN sind für die gute Bindung beider Proteine an Hydroxylapatit verantwortlich. Sie besitzen außerdem eine RGD-Sequenz, bestehend aus den Aminosäuren Arginin, Glycin und Asparaginsäure, aufgrund dessen sie an der Regulation der Zellanhaftung und der Signalweiterleitung der Zellen beteiligt sind (Sodek und McKee 2000).

BSP wird charakteristisch im mineralisierten Knochen exprimiert, vor allem in den oberflächlichen Schichten und der Mineralisationszone, wohingegen das Osteoid frei von diesem Protein ist. Im Gegensatz dazu wird OPN sowohl in unmineralisierten als auch mineralisierten Knochenabschnitten gefunden, vor allem in Gegenden 
des Knochenumbaus nahe der Resorptionszone von Osteoklasten (Pinero et al. 1995). Die Aufgabe von BSP scheint zum einen in der Förderung der Ablagerung anorganischer Mineralien zu liegen, andererseits fördert es die Adhäsion von Osteoklasten und damit den Abbau des Knochens (Young et al. 1992; Raynal et al. 1996). Die Expression von OPN konnte erhöht nachgewiesen werden, unter der Beanspruchung des Zahnes bei kieferorthopädischen Maßnahmen und den damit ausgeübten mechanischen Kräften, was damit zusammenhängt, dass dieses Protein die Anhaftung von Osteoblasten- und klasten fördert (Raynal et al. 1996; Terai et al. 1999). Außerdem kommt es ausgelöst durch BMP7 und TGF- $\beta$, sowie Vitamin $D_{3}$ zu erhöhten Expressionen (Sodek et al. 1995). Die Analyse von Osteopontinknock-out-Mäusen zeigte, dass sich diese physiologisch normal entwickeln und es keine Störungen in der Bildung des Kollagennetzwerkes und der Zusammensetzung der Extrazellulärmatrix gibt (Rittling et al. 1998).

Osteonectin, auch bekannt als secreted protein, acidic and rich in cysteine (SPARC), ist ein 32 kDa großes Glykoprotein, dessen Gen auf Chromosom 5 lokalisiert ist und bis zu 25 \% der nicht-kollagenen Proteine ausmacht (Termine et al. 1981; Zung et al. 1986; Sodek und McKee 2000).

Dieses Protein bindet besonders stark an Hydroxylapatit sowie Kollagen I als auch Kalzium. Im Verbund mit Kollagen I werden $\mathrm{Ca}^{+}$-Ionen besonders gut gebunden und mit den Kollagenfasern vernetzt. Osteonectin ist somit sehr wahrscheinlich an der Mineralisation der Matrix sowie an der Befestigung der Hydroxylapatitkristalle im Kollagennetz beteiligt (Termine et al. 1981). Weitere Affinitäten konnten zu Thrombospondin und $\mathrm{Cu}^{+}{ }^{+}$nachgewiesen werden (Lane und Sage 1994). Vier unterschiedliche Domänen mit verschiedenen strukturellen sowie funktionellen Eigenschaften wurden erkannt. Domäne I ist glutaminsäurereich und zeigt gering-affine kalziumbindende Eigenschaften, wobei sie sich bei der Bindung in eine $\alpha$-Helix umstrukturiert. Die zweite Domäne ist cysteinreich, und Domäne III zeigt proteolytische Eigenschaften, während die vierte Domäne die hoch-affine kalziumbindende EFStruktur enthält. Untersuchungen zeigten, dass das SPARC-Gen keine TATA- und CAAT-Boxen enthält (McVey et al. 1988; Sodek und McKee 2000). Osteonectin scheint anti-adhäsiv zu agieren, da es in der Lage ist, zelluläre Kontakte mit der Knochenmatrix aufzulösen und damit Veränderungen der Zellform herbeizuführen 
(Lane und Sage 1994). Im Maus-Modell konnte gezeigt werden, dass ein SPARCNull-Phänotyp zu weniger und dünnerer Kollagenfaserbildung tendiert (Trombetta und Bradshaw 2010).

Einen weiteren Bestandteil der nicht-kollagenen Proteine bilden die Proteoglykane Dekorin, Biglykan und Osteoadherin (Drenckhahn et al. 2003).

Biglykan und Dekorin, Chondroitinsulfat-Proteoglykan I und II, machen 95 \% der Proteoglykane aus und gehören zur ersten Klasse der SLRP's (small leucinrichProteoglykans). Sie sind in ihrer Struktur 57 \% identisch zueinander, unterscheiden sich jedoch in der Anzahl der gebundenen Chondroitinsulfat-Ketten, wobei Biglykan zwei dieser Ketten bindet und Dekorin nur eine (Fisher et al. 1987; lozzo 1999) . Beide PG`s werden in großen Mengen von Osteoblasten und Osteozyten exprimiert, wobei Biglykan meist auf der Zelloberfläche und in der perizellulären Matrix sowie bereits in undifferenzierten Mesenchymzellen nachzuweisen ist. Ihm wird daher eine Rolle in der osteoblastären Differenzierung und Knochenbildung zugewiesen. Dekorin scheint außerdem an der Orientierung der Kollagenfibrillen und deren Wachstum beteiligt zu sein (Bianco et al. 1990; Fisher et al. 1991). Ihm wurden bereits hohe Affinitäten zu Kollagentyp VI und III nachgewiesen, umso verständlicher, dass Störungen im Dekorin-Gen veränderte Kollagenmorphologien zur Folge haben und es weitergehend zu plumpen, irregulären Faserzusammenlagerungen kommt (Bidanset et al. 1992; Thieszen und Rosenquist 1995; Danielson et al. 1997). Außerdem konnte eine Affinität zu Fibrillin nachgewiesen werden (Trask et al. 2000). Beide SLRP`s können an Tgf- $\beta$ binden und werden daraufhin erhöht produziert (Fisher et al. 1991; Sodek und McKee 2000)

Osteoadherin gehört zur zweiten Klasse der SLRP`s und bindet im Gegensatz zu Dekorin und Biglykan Keratansulfat-Ketten an seinem N-terminalen Ende. Außerdem besitzt es wie alle Gruppenmitglieder eine cysteinreiche Region (lozzo 1999)

Verschiedene zusammenhängende Prozesse führen nach erfolgter Matrixbildung zu deren Mineralisierung. Enzyme innerhalb von extrazellulären Matrixvesikeln können Kalzium und Phosphat in so hohen Konzentrationen binden, dass sich sogenannte Kristallisationskeime in ihnen entwickeln (Anderson 1984; Abramowitz und Suki 1996). Zum anderen lagern sich Proteine, die Hydroxylapatitkristalle binden 
können, in Hohlräume (hole zones) zwischen benachbarten Kollagenfibrillen ein und führen damit ebenfalls zur Bildung von Kristallisationskeimen (Landis 1995). In den Räumen zwischen den Kollagenfasern erfolgt dann die fortlaufende Mineralisierung der Knochenmatrix, wobei weiterhin eine elastizitätsschaffende Kollagenfasermatrix erhalten bleibt (Radlanski 2011).

\subsubsection{Einfluss von Wachstumsfaktoren und Zytokinen}

$\mathrm{Zu}$ diesen Faktoren gehört die Familie der BMP's, von denen erstmals BMP-1, BMP-2a, BMP-2b (jetzt BMP-4) und BMP-3 (Osteogenin) beschrieben wurden, denen damals schon unterschiedliche Funktionen nachgewiesen werden konnten. BMP-2 und-3 wurden erstmals der TGF-Familie zugeschrieben und eine knochenbildende Fähigkeit konnte nachgewiesen werden. BMP`s induzieren chemotaktische und proliferative Prozesse, welche kurzfristig zur Knorpelbildung führten, woraufhin dieser anschließend durch die Ansammlung von Knochen und Knochenmark ersetzt wurde. Im Gegensatz dazu ist BMP-1 an der Interaktion zwischen verschiedenen Proteinen beteiligt und kann Kalzium binden (Wozney et al. 1988; Rosen et al. 1989; Reddi 1998). Mittlerweile wurde eine Reihe an unterschiedlichen BMP`s identifiziert, die an der Regeneration des Alveolarknochens beteiligt sind, darunter BMP-2, -4 und -7, deren Expression immunhistochemisch im Laufe der Heilungsphase, nach Durchführung eines kieferchirurgischen Eingriffes, nachgewiesen werden konnte (Cochran und Wozney 1999; Knabe et al. 2005). In einer Studie wurde außerdem festgestellt, dass die subkutane Injektion von BMP-2 bei Mäusen zur periostalen Knochenbildung geführt hat und in Kultur befindliche Osteoblasten durch BMP-2 angeregt werden, vermehrt BMP-3 und -4 zu produzieren und erhöht osteogene Marker wie Osteocalcin, Osteopontin, BSP, ALP und Kollagentyp I zu synthetisieren (Chen et al. 1997). Abgesehen von BMP-1 wurden alle weiteren Mitglieder dieser Proteingruppe der TGF- $\beta$-Superfamilie zugeordnet (Wozney et al. 1988).

Ebenfalls regulierend auf den Knochen wirken Proteine der TGF-Superfamilie. Sie wird in vier Untergruppen eingeteilt, deren Mitglieder alle zu 64-82 \% identisch sind (Kondaiah et al. 1990; Massagué 1990). Diese Wachstumsfaktoren wirken fördernd 
und regenerativ auf viele unterschiedliche Gewebe und spielen eine große Rolle bei der Zellproliferation. Sie regulieren die Zelladhäsion und erhöhen die Expression von Kollagentyp I, III, V, VI sowie einiger nicht-kollagener Bestandteile der Knochenmatrix. Ihnen konnte auch eine immunsuppressive Wirkung nachgewiesen werden, indem sie die Entwicklung von T- und B-Lymphozyten herunterregulieren. Während der embryonalen Entwicklung können diese Wachstumsfaktoren ebenfalls erhöht nachgewiesen werden, sodass angenommen wird, dass sie bereits in der Entwicklung eine Rolle spielen (Massagué 1990; Kingsley 1994).

Mitogen auf Präosteblasten und stimulierend auf Osteoklasten wirkt der transforming growth factor- $\alpha$ und zeigt damit, dass die Wachstumsfaktoren sowohl einen knochenaufbauenden als auch resorptiven Effekt auf Zellen ausüben. Der transforming growth factor- $\beta$ wirkt dem Knochenabbau entgegen, indem er die Proliferation von Präosteoblasten iniziiert und RANKL bremst (Garant 2003).

Für insulin-like growth factor-I und -II (IGF-I und -II) konnte eine Rolle bei Knochenumbauvorgängen nachgewiesen werden. Beide Faktoren alleine hatten keinerlei Auswirkungen auf die Menge an TRAP-positiven Osteoklasten und deren resorptive Aktivität. Unter der Präsenz von Zellen der osteoblastären Linie sowie der Interaktion der beiden IGF`s mit dem Typ I-IGF-Rezeptor in Osteoblasten, wurde eine erhöhte Produktion von Osteoklasten und mehr resorptive Knochenlakunen nachgewiesen (Hill et al. 1995). Sie stimulieren allerdings auch die Synthese von Präosteoblasten und Osteoblasten, ebenso wie die Bildung der Kollagenfasern. Die Regulation von IGF-1 durch verschiedene Wachstumsfaktoren wurde ausführlich untersucht, wobei festgestellt wurde, dass TGF- $\beta_{1}$, bFGT (basic fibroblast growth factor) und PDGT (plateled-derived growth factor) einen herunter regulierenden Effekt auf die Expression von IGF-1 haben (Baylink et al. 1993; Canalis et al. 1993).

\subsubsection{Unterschiede osteoblastärer Zellen zu anderen Zelltypen}

In den letzten Jahren sind viele Theorien über die Verwandtschaft zweier Zelltypen, der Osteoblasten und der Zementoblasten, entstanden. Es wird diskutiert, ob diese beiden Zellgruppen nicht voneinander zu unterscheiden sind, oder ob es sich bei 
dem Zementoblast um einen eigenen Phänotypen handelt (Bosshardt 2005). Kürzlich wurde das Genprofil der beiden Zellenarten umfangreich im Maus-Model analysiert und ausgewertet. Dabei konnten viele verschiedene Marker, wie beispielsweise OPN und BSP in beiden Zellen nachgewiesen werden, wobei das Level der Expression deutlich unterschiedlich war. 95 der nachgewiesenen Gene wurden doppelt so hoch in Zementoblasten exprimiert, als in Osteoblasten. Die analysierten Zellen stammen allerdings aus der Maus, weshalb die gewonnenen Ergebnisse nicht sicher auf den Menschen übertragbar sind (Matthews et al. 2016). CP-23, auch bekannt als Cementum Protein-1 und CEMP1, scheint bisher der einzige Marker zu sein, der Zement- sowie PDL-spezifisch ist und bislang nicht im Knochen nachweisbar war (Alvarez-Pérez et al. 2006). Dieses Protein ist nicht nur ein Marker für Zellen der zementoblastären Linie, sondern spielt außerdem eine Rolle während der Differenzierung von PDL-Zellen zu Zementoblasten. In einer Überexpression von CP23 wurden erhöhte Differenzierungen nachgewiesen, wohingegen es weniger osteoblastäre Entwicklungen gab (Komaki et al. 2012). Aufgrund dieser Erkenntnisse haben wir CP-23 in unseren Forschungsumfang aufgenommen, um nachzuweisen, ob dieses Protein auch im humanen Alveolarknochen als Unterscheidungsmerkmal der beiden Zelltypen dient.

Weiterhin sind einige Untersuchungen mit der eindeutigen Unterscheidung von Osteoblasten und Osteozyten beschäftigt. Auch hier wurde ein umfangreiches Genprofil angelegt, um Unterschiede vor allem in der Expression nicht-kollagener Knochenmatrixproteine zu finden. Diese Versuche sind mit Zellen aus der Schädelkalotte der Maus durchgeführt worden und daher auch nicht eindeutig auf den Menschen übertragbar. Es konnte außerdem das Sost-Gen, welches Sclerostin generiert, nicht nachgewiesen werden (Paic et al. 2009). Sclerostin scheint bisher der einzige Osteozyten-spezifische Marker zu sein, welcher außerdem die Knochenbildung inhibiert. Im Maus-Modell wurde gezeigt, dass unter Belastung der Nachweis von Sclerostin-positiven Zellen zurückging und die Knochenbildung angeregt wurde (Robling et al. 2008). In einer weiteren Forschungsarbeit konnte allerdings festgestellt werden, dass es zu einer Sclerostin induzierten Reaktivierung von Knochensaumzellen zu aktiven Osteoblasten kommt (Kim et al. 2017). Aufgrund der Spezifität haben wir Sclerostin ebenfalls in unsere Experimente mit einbezogen, wovon 
angenommen wurde, dass keine Expression in den osteoblastären Zellen nachzuweisen ist.

\subsection{Aufgabenstellung}

Das Ziel der vorliegenden Arbeit ist es, osteoblastäre Zellen aus dem humanen Alveolarknochen, die bisher gänzlich unerforscht sind, zu charakterisieren und hinsichtlich ihrer Unterschiede zu anderen verwandten Zellgruppen zu untersuchen. Dafür werden diese Zellen erstmalig in verschiedenen Ebenen auf die folgenden Markerproteine untersucht: Osteocalcin, Osteopontin, Osteonectin, Bone Sialoprotein, Kollagen I und III, Vegf, Runx2 sowie Sox9 und die Proteoglykane Dekorin und Versikan. Diese sogenannten Marker sind bisher in Zellen der osteoblastären Linie gefunden worden, wobei keinerlei Ergebnisse aus dem Alveolarknochen stammen. Im Gegensatz dazu, konnte sowohl CP-23 als auch Sclerostin bisher nicht in Osteoblasten nachgewiesen werden. Aufgrund eines bestehenden Zusammenhangs zwischen der Expression von Runx2 und Sox9 haben wir dieses Protein ebenfalls analysiert (Koelling et al. 2009). Die Markernachweise sollen in unterschiedlichen Versuchsverfahren erfolgen um eine möglichst genaue Analyse zuzulassen. 


\section{Material und Methoden}

Im Folgenden werden sämtliche Methoden sowie Materialien gelistet und beschrieben, die an der Gewinnung der Ergebnisse dieser Arbeit beteiligt waren. Eventuell auftretende Besonderheiten werden in den Unterkapiteln näher erläutert.

\subsection{Gewebeproben und Zellgewinnung}

Alle für diese Arbeit hinzugezogenen Zellen wurden nach einer Zahnextraktion in dem Universitätsklinikum Göttingen gewonnen und für die AG orale Biologie und Geweberegeneration zur Verfügung gestellt (Ethik-Kommission der Medizinischen Fakultät der Georg-August-Universität Göttingen 16/06/09).

Alveolarknochenstücke konnten in sogenannte 6-Well-Platten überführt werden und durch die Zugabe des Breitbandantibiotikums Gentamycin wurden verbliebene Bakterien abgetötet. Anschließend wurden Deckgläschen (DG) in jedes Well gelegt und angedrückt, hierdurch sollte der Kontakt von den Proben zum Boden der Kulturgefäße verbessert werden, wodurch das Auswachsen der osteoblastären Zellen erleichtert wird. Nach einer Inkubation von 8-10 Tagen im Brutschrank wurden die DG sowie verbliebenes Gewebe entfernt und die Zellen konnten zur Kultivierung in Flaschen überführt werden.

Dankenswerterweise wurden die Zellen von Frau Christa Bode aus der AG orale Biologie und Geweberegeneration der Universität Göttingen durch Transfektion mit hTERT immortalisiert und in einem Einfriermedium, bestehend aus $10 \%$ DMSO, 20 $\%$ FBS und $70 \%$ Nährmedium in Stickstoff gelagert.

Die für diese Arbeit aufgetauten osteoblastären Zellen wurden unter sterilen Bedingungen auf mehrere $75 \mathrm{~cm}^{2}$ große Zellkulturflaschen verteilt, die mit $10 \mathrm{ml}$ Dulbecco's Modified Eagle's Medium (DMEM) versetzt wurden. Die Flaschen sind bei $37^{\circ} \mathrm{C}$ und $5 \% \mathrm{CO}_{2}$-Begasung für mehrere Tage im Brutschrank gelagert worden, um eine ausreichend große Menge an Zellen für die folgenden Versuche heranzuzüchten. 


\subsection{Zellkultur}

Tabelle 1: Medium/Nährmedium

\begin{tabular}{lcc}
\hline \multirow{2}{*}{ Medium } & Gibco by life technologies Corporation \\
& DMEM Medium & DMEM (1x) + GlutaMax \\
Nährmedium & Daisley, United Kingdom \\
\hline
\end{tabular}

Innerhalb mehrerer Tage wurde das Wachstum der osteoblastären Zellen unter dem Mikroskop beobachtet und bei einer Konfluenz von 80-90 \% wurden die Zellen geerntet. Im ersten Schritt wurde das alte Nährmedium in einen Messbecher abgeschüttet und zweimal mit PBS-Puffer gespült. Anschließend wurde in jede Flasche $2 \mathrm{ml}$ Trypsin (PAN Biotech, Aidenbach) hineinpipettiert und durch leichtes Schwenken gleichmäßig auf dem gesamten Flaschenboden verteilt. Nach einer Lagerung von 2-3 Minuten im Brutschrank wurde leicht auf die Flaschenseite geklopft und unter dem Mikroskop beobachtet, ob alle adhärenten Zellen vom Boden gelöst wurden und frei im Trypsin schwammen. Das Zell-Trypsin-Gemisch wurde in ein $50 \mathrm{ml}$ Falcon Tube Röhrchen überführt und die Wirkung des Trypsins durch das gleiche Volumen an Medium gehemmt. Anschließend wurde nochmals mit ca. $2 \mathrm{ml}$ Medium gespült, um alle Zellreste vollständig in das Falcon Röhrchen zu überführen. Nach zehnminütiger Zentrifugation des Röhrchens bei 1200 rpm wurde der Überstand weggeschüttet und das Zellpellet in $1 \mathrm{ml}$ PBS resuspendiert. Die Zellzahl wurde mit Hilfe eines Zellometers (Cellometer Auto T Cell Counter, Nexelcom Bioscience, Lawrence, USA) ermittelt. Hierfür wurden $20 \mu$ in einen Zellträger pipettiert, der mit dem Zellometer verwendet werden konnte. Die gewünschte Zellzahl wurde ermittelt um diese anschließend erneut zu kultivieren. Es wurden beispielsweise $6 \times 10^{4} \mathrm{Zel}-$ len in die mit $10 \mathrm{ml}$ frischem Nährmedium befüllten Zellkulturflaschen gegeben und bei $37^{\circ} \mathrm{C}$ weiter kultiviert. Sollte ein Zellpellet bei $-81^{\circ} \mathrm{C}$ für einen längeren Zeitraum gelagert werden, wurde die entsprechende Zellzahl, meist $1 \times 10^{6}$, in ein E-Cup pipettiert und der Überstand nach erneuter zehnminütiger Zentrifugation abgenommen. 
Die beschriebenen Arbeitsschritte erfolgten alle unter der sterilen Zellbank und wurden anschließend mit Datum, Zellreihe, Zellzahl und Passage dokumentiert.

\subsection{Osteogene Stimulation}

Die für diese Studie verwendeten Osteoblasten wurden nicht nur immortalisiert, sondern auch osteogen differenziert. Hierzu wurden Ascorbinsäure-2-Phosphat (Vit C) und $\beta$-Glycerolphosphat über einen Zeitraum von ca. 2 Wochen dem oben angegebenen Medium beigesetzt, wobei dieses nach wie vor in regelmäßigen Abständen gewechselt wurde. Nach 14 Tagen konnte optisch eine Veränderung der Zellen festgestellt werden, wobei sich vor allem der Zellkörper deutlich breiter darstellte und die Zellen geerntet wurden.

Ascorbinsäure-2-Phosphat $10 \mathrm{mM}=25,6 \mathrm{mg} / 10 \mathrm{ml} \quad 12 \mu \mathrm{l} / 12 \mathrm{ml}$ Flasche

$\beta$-Glycerolphosphat $\quad 1 \mathrm{M}=2,16 / 10 \mathrm{ml} \quad 120 \mu \mathrm{l} / 12 \mathrm{ml}$ Flasche

\section{4 mRNA-Isolation aus primären Zellen}

Zur mRNA-Isolation aus primären Zellen wurden zum Teil bei $-81^{\circ} \mathrm{C}$ tiefgefrorene Zellpellets aufgetaut oder gerade geerntete Zellen sowie das peqGOLD Total RNA Kit der Firma PeqLab verwendet. Die Isolation erfolgte jeweils nach folgendem Prinzip. Zunächst wurde das Zellpellet mit $400 \mu \mathrm{l}$ RNA Lysis Buffer T resuspendiert. Die gesamte Gewebe-Lyse-Mischung wurde auf ein grünes, bereits vorbereitetes, DNA Removing Column gegeben und eine Minute bei 12.000 xg zentrifugiert. Nach Verwerfen der grünen Säule wurde die Flüssigkeit mit $400 \mu \mathrm{l} 70$ \%igem Ethanol vermischt und auf ein ebenfalls vorbereitetes orangenes DNA Removing Column gegeben. Es wurde erneut eine Minute bei 10.000 xg zentrifugiert und dieses Mal der Überschuss verworfen. Darauffolgend wurde dreimal gewaschen, einmal mit $500 \mu \mathrm{l}$ RNA Wash Buffer I und zweimal mit $600 \mu \mathrm{L}$ RNA Wash Buffer II, wobei hierbei darauf zu achten war, dass der RNA Wash Buffer II mit 80 ml 100 \%igem Ethanol versetzt worden ist. Zwischen den Waschvorgängen wurde $15 \mathrm{sec}$ bei 10.000 xg 
zentrifugiert und nach dem letzten Vorgang zwei Minuten bei 10.000xg trockenzentrifugiert. Im letzten Schritt wurden 50-100 $\mu$ RNase-freies Wasser auf die Matrix gegeben und für drei Minuten bei Raumtemperatur inkubiert. Ein letztes Mal wurde für eine Minute bei 5.000 xg zentrifugiert und das Column verworfen.

Mit Hilfe des Spectrophometers NanoDrop1000 (Peqlab Biotechnologie GmbH) wurde die Menge an mRNA in ng/ $\mu$ l ermittelt und die mRNA bei $-81^{\circ} \mathrm{C}$ tiefgefroren oder zur direkten Überführung in cDNA verwendet.

\subsection{Synthese von cDNA}

Zur Durchführung der Polymerase-Kettenreaktion muss die gewonnene mRNA in cDNA umgeschrieben werden. Hierzu wird das QuantiTect Reverse Transkription Kit (QIAGEN) genutzt.

Als Vorbereitung musste ein Wasserbad auf $42{ }^{\circ} \mathrm{C}$ und ein Bad auf $95{ }^{\circ} \mathrm{C}$ erhitzt werden und die Menge an $\mu$ lermittelt werden, in denen sich 200 ng mRNA befinden. Hatte man die Menge an $\mu \mathrm{l}$ mRNA ermittelt und $2 \mu \mathrm{l}$ gDNA Wipeout Puffer dazugegeben, wurde das Gesamtvolumen mit RNAse freiem $\mathrm{H}_{2} \mathrm{O}$ auf $14 \mu$ l aufgefüllt und die Mischung anschließend für 2 Minuten bei $42{ }^{\circ} \mathrm{C}$ in einem Thermomixer (Thermomixer comfort, Eppendorf) inkubiert, um mögliche Reste an DNA zu entfernen.

Daraufhin wurden $4 \mu$ Transkriptionspuffer, $1 \mu$ l Reverse Transkriptase und $1 \mu \mathrm{l}$ Primer-Mix hinzugegeben, womit ein Gesamtvolumen von $20 \mu$ erreicht wurde. Die Probe wurde nun für 15 Minuten bei $42{ }^{\circ} \mathrm{C}$ inkubiert, um in diesem Schritt die eigentliche Umschreibung von mRNA in cDNA durchzuführen. Bei $95^{\circ} \mathrm{C}$ wurde die Probe für 3 Minuten erhitzt und damit die reverse Transkriptase inaktiviert und die gebildeten Stränge voneinander gelöst. Daraufhin wurde mit RNAse freiem $\mathrm{H}_{2} \mathrm{O}$ auf $200 \mu$ l aufgefüllt.

Man ging davon aus, dass die Umschreibung von mRNA zu cDNA im Verhältnis 1:1 stattfand, somit erlangte man eine cDNA-Konzentration von $200 \mathrm{ng} / \mu \mathrm{lbzw} 1 \mathrm{ng} / \mu \mathrm{l}$ Die gewonnene cDNA konnte bei $-20{ }^{\circ} \mathrm{C}$ über einen längeren Zeitpunkt aufbewahrt werden oder direkt im Verfahren der quantitativen Echtzeit-Polymerase-Kettenreaktion verwendet werden. 


\subsection{Polymerase-Kettenreaktion}

\subsubsection{Allgemeines zur PCR}

Bei dem Verfahren der Polymerase-Kettenreaktion (Polymerase-Chain-Reaction = PCR) werden in einem sogenannten Thermocycler bestimmte DNA-Abschnitte amplifiziert und quantifizierbar gemacht. In einem Thermocycler werden ca. 30-50 Zyklen durchlaufen, wobei jeder Zyklus aus Denaturierung, Hybridisierung und Polymerisation besteht.

Im Schritt der Denaturierung wird die DNA auf $95^{\circ} \mathrm{C}$ erhitzt, wobei sich die Wasserstoffbrückenbindungen lösen und die DNA, ebenso wie die Primer in Einzelsträngen vorliegen. Im darauffolgenden Schritt der Hybridisierung wird die Temperatur auf die Primer-spezifische Annealing-Temperatur heruntergekühlt, bei der die beiden Primer (forward/reverse) an die DNA binden. Daraufhin erfolgt die Elongation ausgehend von den Primern in 5`3`-Richtung, wobei der komplementäre Strang synthetisiert wird. Hierfür wird die Temperatur optimal für die Taq-Polymerase erwärmt. Bei jedem zu durchlaufenden Zyklus steigt die Menge der DNA-Doppelstränge exponentiell an, sodass nach 1-2 Stunden genügend Erbgut vervielfältigt worden ist und der Vorgang abgeschlossen ist. Notwendig für diese Vorgänge sind bestimmte Enzyme, sogenannte DNA-Polymerasen (Taq-Polymerasen), freie Nukleotide (dNTP) und zwei spezifische Primer.

\subsubsection{Quantitative Echtzeit-PCR}

Die quantitative real-time PCR (qRT-PCR) beruht auf einer Weiterentwicklung der Polymerase-Kettenreaktion. Hier ist es möglich, die Genexpression zu messen und schon während der Reaktion die vervielfältigten Nukleinsäuresequenzen zu quantifizieren. Zunächst wird mRNA aus den Zellen isoliert und in cDNA umgeschrieben. Diese cDNA wird verwendet, um nachzuweisen, dass bestimme Gene in den Zellen transkribiert worden sind. Mit Hilfe eines interkalierenden Fluoreszenzfarbstoffes, des sogenannten SYBR-Green, der dem Reaktionsansatz zugesetzt wird, werden Rückschlüsse auf die eingesetzte Menge des gesuchten Produkts möglich. Dieses Fluorochrom bindet an die neu synthetisierten DNA-Doppelstränge und fluoresziert 
hierbei, wobei die Fluoreszenz ebenfalls exponentiell ansteigt. Je stärker die gemessene Fluoreszenz nach Beendigung der Elongation ist, desto mehr Kopien des gesuchten Abschnitts liegen vor. Zur Messung der Amplifizierung wird ein Schwellenwert festgelegt (cycle threshold, Ct-Wert), bei dessen erstmaligem Überschreiten der entsprechende Zyklus vom Thermocycler gemessen wird. An diesem Punkt steigt die gemessene Fluoreszenz zum ersten Mal signifikant über die Hintergrundfluoreszenz. Je früher dieser Schwellenwert erreicht wird umso mehr mRNA des entsprechenden Gens lag in der Probe vor. Ist der Ct-Wert im Gegensatz sehr hoch, weist dies darauf hin, dass sich nur wenig mRNA des entsprechenden Gens in der Probe befand.

\subsubsection{Protokoll der qRT-PCR}

Tabelle 2: KAPA SYBR Fast qPCR Kit (peqlab)

\begin{tabular}{|c|c|}
\hline \multirow{3}{*}{ Primer-Mix } & $20 \mu l$ forward \\
\hline & $20 \mu$ reverse \\
\hline & $160 \mu \mathrm{l} \mathrm{H}_{2} \mathrm{O}$ \\
\hline \multirow{3}{*}{$\begin{array}{l}\text { Master-Mix } \\
\text { (1Ansatz) }\end{array}$} & $5 \mu \mathrm{l}$ SYBR-Green \\
\hline & $2 \mu \mathrm{l}$ Primer-Mix \\
\hline & $2 \mu \mathrm{l} \mathrm{H}_{2} \mathrm{O}$ \\
\hline & $9 \mu l+1 \mu l \mathrm{cDNA}$ \\
\hline
\end{tabular}

Zunächst wurde für den entsprechenden Primer ein Primer-Mix aus jeweils $20 \mu \mathrm{l}$ forward- und reverse-Primer sowie $160 \mu \mathrm{H}_{2} \mathrm{O}$ angesetzt. Dieser ist anschließend über mehrere Wochen bei $-20^{\circ} \mathrm{C}$ aufzubewahren und zu verwenden. Aus diesem Ansatz wurden pro Master-Mix-Ansatz $2 \mu$ zusammen mit $5 \mu$ SYBR-Green und $2 \mu \mathrm{l}$ RNAse-freiem Wasser pipettiert. Dieser Ansatz wurde gemischt und kurz abzentrifugiert. Wir haben für unsere Versuche jeweils $31 / 2$ Ansätze pipettiert, um eventuellen Pipettierfehlern vorzubeugen, und pro Ansatz jeweils in 6 Wells pipettiert. Pro Well wurden $9 \mu$ des vorbereiteten Master-Mix-Ansatzes pipettiert und erst anschließend $1 \mu \mathrm{l}$ cDNA separat dazu gegeben. Alle Versuche wurden auf Eis dur- 
chgeführt und die 96-Well-Platten zunächst mit einem Dichtfilm (Microseal B Adhesive, Biozym) beklebt, welcher anschließend mit einem Skalpell freigeschnitten wurde. Nach Verteilung des Master-Mix-Ansatzes und cDNA wurden die Wells mit Flat Cap Strips (Biozym) verschlossen und kurz abzentrifugiert. Die 96-Well-Platten konnten dann bis zur Verwendung für einige Tage tiefgefroren werden oder direkt in den Mastercycler (Eppendorf) plaziert werden, um den PCR Vorgang nach folgendem Programm der Realplex-Software zu starten.

Tabelle 3: Zyklusablauf im Thermocycler (Eppendorf)

\begin{tabular}{cccc}
\hline Phase & Temperatur & Zeit & Zyklen \\
\hline Initiale Aktivierung & $95^{\circ} \mathrm{C}$ & $5 \mathrm{~min}$ & \\
\hline Denaturierung & $95^{\circ} \mathrm{C}$ & $15 \mathrm{sec}$ & \\
\hline Annealing & Primer-spezifisch & $15 \mathrm{sec}$ & $45 \mathrm{X}$ \\
\hline Elongation & $72^{\circ} \mathrm{C}$ & $20 \mathrm{sec}$ & \\
\hline Finale Extension & $72^{\circ} \mathrm{C}$ & $10 \mathrm{~min}$ & \\
\hline Schmelzkurve & $\mathrm{Ann} . \mathrm{Temp}^{-}-1^{\circ} \mathrm{C}$ bis $95^{\circ} \mathrm{C}$ & $15 \mathrm{sec}, \mathrm{je} 8$ \\
& in $0,2{ }^{\circ} \mathrm{C}$ Schritte & $\mathrm{sec}$ \\
\hline
\end{tabular}

\subsubsection{Housekeeping-Gene}

Als sogenannte Housekeeping-Gene (HKG) werden Gene bezeichnet, bei denen davon ausgegangen wird, dass ihr Expression homogen abläuft und möglichst unabhängig von intra-und extrazellulären Prozessen erfolgt. Deshalb sind sie besonders wichtig für die statistische Auswertung einer PCR als interne Referenzgröße, um methodische Unterschiede zu eliminieren. In dieser Arbeit wurde das HKG Lamin A/C verwendet, ein Intermediärfilament, dass im Zellkern aller eukaryotischen Zellen zu finden ist. 
Tabelle 4: HKG

\begin{tabular}{cccc}
\hline \multirow{2}{*}{ Protein } & Richtung & $\mathbf{5}^{\prime} \mathbf{3}^{\prime}$-Richtung & $\begin{array}{c}\text { Annealing- } \\
\text { Temp. }\end{array}$ \\
\hline \multirow{2}{*}{ Lamin A/C } & vorwärts & ggtcactggaaaggg- & \\
\cline { 2 - 3 } & & gaga & $60{ }^{\circ} \mathrm{C}$ \\
& rückwärts & ttgctttggggag- & \\
& & gagaga & \\
\hline
\end{tabular}

\subsubsection{Gradienten-PCR}

Diese Methode wurde genutzt, um die ideale Annealing-Temperatur für forwardund reverse-Primer festzulegen. Diese Temperatur entscheidet über das Anlagerungsverhalten der beiden Primer an die DNA-Zielstränge und ist somit ein wichtiger Faktor bei der Durchführung der Polymerase-Kettenreaktion. Wenn diese Temperatur zu niedrig ist kommt es zu unerwünschten unspezifischen Bindungen. Ist sie zu hoch, können sich die Primer nicht anlagern.

Zur Durchführung wurde wie zuvor beschrieben ein Primer-Mix für den entsprechenden Primer pipettiert und dieser für weitere Master-Mix-Ansätze verwendet. Eine 96-Well-Platte wurde vorbereitet und für die Gradienten-PCR lediglich die Wells 512 freigeschnitten, die Wells 1-4 wurden nicht verwendet. Im PCR-Programm wurde ein Temperatur-Gradient zwischen der linken und rechten Blockseite generiert. Die Temperaturen lagen von links nach rechts bei $50,7^{\circ} \mathrm{C}, 53,1^{\circ} \mathrm{C}, 55,5^{\circ} \mathrm{C}, 57,9^{\circ} \mathrm{C}$, $60,0^{\circ} \mathrm{C}, 61,6{ }^{\circ} \mathrm{C}, 62,7^{\circ} \mathrm{C}$ und $63^{\circ} \mathrm{C}$. Nach dem PCR-Durchlauf wurden sich die einzelnen Schmelzkurzen der verschiedenen Temperaturen angeschaut und miteinander verglichen. Die Kurve mit der höchsten Extinktion, einem hohen schlanken Peak, wurde als die ideale Kurve festgelegt und die entsprechende Temperatur als Annealing-Temperatur des Primers bestimmt. Diese Gradienten-PCR haben wir für die von uns neu designten Primer Versikan und CP-23 durchgeführt.

\subsubsection{Primerdesign}

Einige der von uns für die qRT-PCR genutzten Primer wurden zuvor über die Primer3-Software (www.primer3.ut.ee) designt. Beim Primerdesign war auf folgende 
Richtlinien zu achten. Maximal 200 Basenpaare des gebildeten Produktes, eine Länge der Primer zwischen 18 und 22 Basenpaaren, ein GC-Gehalt zwischen 40 $60 \%$ und eine maximale Abweichung der Annealing-Temperaturen des forwardund reverse- Primers von $1,0^{\circ} \mathrm{C}$. Mit Hilfe des Basic-Local-Alignment-Search-Tools (http://blast.ncbi.nlm.nih.gov/Blast.cgi) wurde die designte Sequenz auf Alignements überprüft. Die Synthese und Lieferung wurde von der Firma Operon Biotechnologie $\mathrm{GmbH}$ (Köln, Deutschland) gewährleistet. Nach Lieferung der Primer wurden diese zunächst nach Herstellerangaben in RNAse-freiem Wasser resuspendiert und anschließend bei $-21^{\circ} \mathrm{C}$ gelagert.

Tabelle 5: qPCR-Primer

\begin{tabular}{|c|c|c|c|}
\hline Protein & Richtung & 5'-3'Richtung & $\begin{array}{c}\text { Annealing- } \\
\text { Temp. }\end{array}$ \\
\hline \multirow{2}{*}{ Collagen I } & vorwärts & ttcccccagccacaaagagtc & \multirow{2}{*}{61} \\
\hline & rückwärts & cgtcatcgcacaacacct & \\
\hline \multirow{2}{*}{ Dekorin } & vorwärts & tcttcccctgacacaact & \multirow{2}{*}{56} \\
\hline & rückwärts & cgttccaacttcaccaaag & \\
\hline \multirow{2}{*}{ sox9 } & vorwärts & caggctttgcgatttaagga & \multirow{2}{*}{60} \\
\hline & rückwärts & ccgttttaaggctcaaggtg & \\
\hline \multirow{2}{*}{ Versikan } & vorwärts & ggctccctctctggaaaagt & \multirow{2}{*}{60} \\
\hline & rückwärts & cgggagaaattcactggtgt & \\
\hline \multirow{2}{*}{ CP-23 } & vorwärts & tgagaacctcacctgcctct & \multirow{2}{*}{63} \\
\hline & rückwärts & accccttaggaagtggetgt & \\
\hline \multirow{2}{*}{ Osteocalcin } & vorwärts & caggagggaggtgtgtgag & \multirow{2}{*}{56} \\
\hline & rückwärts & aaggggaagaggaaagaagg & \\
\hline \multirow{2}{*}{ VEGF } & vorwärts & tccaacttctgggctgttct & \multirow{2}{*}{57} \\
\hline & rückwärts & cccctctcctcttccttctc & \\
\hline \multirow{2}{*}{ RUNX2 } & vorwärts & ttccagaccagcagcactc & \multirow{2}{*}{63} \\
\hline & rückwärts & cagcgtcaacaccatcatt & \\
\hline Osteopontin & vorwärts & actgattttcccacggac & 61,6 \\
\hline
\end{tabular}




\begin{tabular}{|c|c|c|c|}
\hline & rückwärts & attcaactcctcgetttcc & \\
\hline \multirow{2}{*}{ BSP } & vorwärts & gcagtagtgactcatccgaagaa & \multirow{2}{*}{58} \\
\hline & rückwärts & gcctcagagtcttcatcttcattc & \\
\hline \multirow{2}{*}{ ALP } & vorwärts & ccacgtcttcacatttggtg & \multirow{2}{*}{60} \\
\hline & rückwärts & agactgcgcctggtagttgt & \\
\hline \multirow{2}{*}{ RANKL } & vorwärts & accagcatcaaaatcccaag & \multirow{2}{*}{60} \\
\hline & rückwärts & taaggaggggttggagacct & \\
\hline \multirow{2}{*}{ Sclerostin } & vorwärts & cacccctccatctcaaagaa & \multirow{2}{*}{60} \\
\hline & rückwärts & tgagtttgtgatggctgctc & \\
\hline
\end{tabular}

\subsubsection{Statistische Auswertung der Analyse - Pfaffl}

Die gewonnenen CT-Werte wurden in das statistische Datenauswertungsprogramm nach Pfaffl (2001) eingetragen, mit dessen Hilfe eine Normalisierung und Quantifizierung der PCR-Daten erfolgte. Hierbei wurde das Housekeeping-Gen Lamin A/C für die Normalisierung verwendet, da dies keinen externen und internen Schwankungen unterliegt und in allen Geweben zeitlich unabhängig exprimiert wird. Außerdem wurde die Expression der Probe auf die Expression der Kontrollprobe, hier den humanen Zementoblasten, bezogen. Hierdurch ergibt sich der $\Delta \Delta \mathrm{CT}$-Wert. Die Expressionsunterschiede lassen sich durch die Anwendung der Formel $2^{-\triangle \Delta C T}$ ermitteln. Um die Reproduzierbarkeit der Ergebnisse zu prüfen, wurden sie dreimal wiederholt und aus der Gesamtheit der Expressionsunterschiede eine Standartabweichung sowie ein Mittelwert gebildet. Die gewonnenen Werte wurden zur Erstellung von Diagrammen verwendet, in denen die Expressionen im Vergleich zur Kontrolle dargestellt wurden. Die Ergebnisse wurden mit dem Shapiro Wilk Test auf der Internetseite http://sdittami.altervista.org/shapirotest/ShapiroTest.html auf eine Normalverteilung überprüft. 


\subsection{Immunzytochemie}

\subsubsection{Allgemeines zur Immunzytochemie}

Die Immunzytochemie unterliegt einer sogenannten Antigen-Antikörper-Reaktion. Zunächst wird mit Hilfe eines proteinspezifischen primären Antikörpers (AK) eine Bindung zu dem Oberflächenantigen des gesuchten Proteins hergestellt, woraufhin ein sekundärer fluoreszenzmarkierter Antikörper eine Bindung mit dem ersten Antikörper eingeht. Die Fluoreszenzfarbstoffe können durch Licht angeregt werden und deren Fluoreszenz mittels Mikroskop registriert werden.

Tabelle 6: Reagenzien

\begin{tabular}{cc}
\hline Reagenz & Zusammensetzung \\
\hline $\mathbf{2} \%$ Paraformaldehyd in PBS & $0.5 \mathrm{~g} \mathrm{PFA}$ in 25 ml PBS \\
& bei ca. $70{ }^{\circ} \mathrm{C}$ im Wasserbad lösen \\
\hline $\mathbf{0 , 2 5} \%$ Triton X-100 in PBS & $0,125 \mathrm{~g}$ Triton X-100 in $50 \mathrm{ml}$ PBS \\
\hline 1\% BSA in PBS & $0,5 \mathrm{~g} \mathrm{BSA}$ in $50 \mathrm{ml}$ PBS sterilfiltriert \\
\hline
\end{tabular}

\subsubsection{Versuchsdurchführung}

Wie zuvor beschrieben, wurden die osteoblastären Zellen nach Kultivierung geerntet, um sie anschließend für die Immunzytochemie auszusähen. Hierfür wurden sterile DG mit einer Pinzette in jedes Well einer 24-Well-Platte gelegt und die gesamte Platte anschließend für mindestens eine viertel Stunde mit UV-Licht bestrahlt, um diese zu sterilisieren. Die Platten konnten daraufhin mit Parafilm verschlossen werden oder die zuvor geernteten Zellen in die Wells ausgesät werden. Für diese Arbeit wurden $5 \times 10^{3}$ Zellen mit $1 \mathrm{ml}$ DMEM in jedes Well pipettiert und die Platte anschließend für ca. 1 Woche bei $37^{\circ} \mathrm{C}$ im Brutschrank aufbewahrt. Sobald die Zellen ausreichend konfluent gewachsen waren, wurde der Versuch vorbereitet. Hierfür wurde das Nährmedium zunächst unter sterilen Bedingungen mit einer Wasserstrahlpumpe abgesaugt und $2 X$ mit $100 \mu$ PBS pro Well gewaschen. Anschließend wurden 
die DG mit der Pinzette aus den Wells genommen und auf eine mit Parafilm überzogene Box gelegt. Hier war stets darauf zu achten, dass die DG niemals trocken lagen und mit einer ausreichenden Menge an PBS benetzt waren. Zur Fixierung der Zellen wurde jedes DG für 15 Minuten mit $100 \mu \mathrm{l} 2 \%$ igem Paraformaldehyd in PBS bei Raumtemperatur inkubiert. Anschließend wurde erneut 2X mit $100 \mu$ PBS pro DG gewaschen, um sämtliche Paraformaldehydreste zu entfernen. Im nächsten Schritt erfolgte die Permeabilisierung der Zellmembran durch eine zehnminütige Inkubation mit $100 \mu$ 0,25 \%igem Triton-X 100 in PBS bei Raumtemperatur woraufhin 2-3 Mal mit $100 \mu$ I PBS pro DG gewaschen wurde, um alle Tritonreste zu entfernen. Um die Spezifität des primären Antikörpers zu erhöhen wurde für 15 Minuten mit 1 $\%$ BSA in PBS geblockt, $100 \mu$ pro DG. Es wurden insgesamt 9 verschiedene AK verwendet, wobei einige davon 1:50 und andere 1:20 in 1\% BSA verdünnt wurden. Je nachdem wurden dementsprechend $245 \mu \mathrm{l} 1 \%$ BSA und $5 \mu \mathrm{l}$ prim AK oder 247 $\mu \mathrm{l} 1 \%$ BSA und $13 \mu \mathrm{l}$ prim Ak vorbereitend in ein E-Cup pipettiert. Aus diesen Vorverdünnungen wurden $100 \mu \mathrm{l}$ auf die entsprechenden DG gegeben und die gesamte Box in einer geschlossenen Schachtel, für 60 Minuten bei $37^{\circ} \mathrm{C}$, in einer feuchten Kammer inkubiert. Auf die beiden Negativkontrollen wurde lediglich PBS gegeben. Nach der Inkubation wurde zweimal mit $100 \mu$ l PBS pro DG gewaschen und anschließend die DG mit dem Sekundärantikörper, für weitere 60 Minuten bei $37^{\circ} \mathrm{C}$, im Brutschrank inkubiert. Auch die Negativkontrollen wurden mit dem Sekundärantikörper inkubiert, um eine mögliche unspezifische Bindung des AK auszuschließen. In diesem Versuch wurden die Sekundärantikörper 1:1000 in 1\% BSA vorverdünnt und waren mit dem Fluoreszenzmarker Alexa Fluor 555 (rot) als auch 4',6-Diamidin2-phenylindol (DAPI, blau) gekoppelt. Der Fluoreszenzfarbstoff DAPI diente der Färbung des Nukleus. Im Anschluss wurde erneut 2X mit $100 \mu$ I PBS pro DG gewaschen und daraufhin mit dem Eindeckeln begonnen. Hierfür sind $10 \mu \mathrm{l}$ Moviol auf einen Objektträger getropft worden und die DG mit der zellenbehafteten Seite nach unten auf den Objektträger gedrückt sowie überschüssiges Moviol abgesaugt. Anschließend wurden die Zellen mit dem Keyence Mikroskop der Serviceeinheit MOLCI der Universität Göttingen fotografiert und konnten einige Zeit in einem Kühlschrank bei $-4{ }^{\circ} \mathrm{C}$ aufbewahrt werden. 
2.7.3 Verwendete Antikörper in der Immunzytochemie

Tabelle 7: Immunzytochemie: primäre Antikörper

\begin{tabular}{ccccc}
\hline Name & Spezies & poly/mono & Herkunft & Verdünnung \\
\hline CP23 & Mensch & polyclonal & Maus & $1: 20$ \\
\hline Collagen I & Mensch & monoclonal & Maus & $1: 50$ \\
\hline Collagen III & Mensch & polyclonal & Kaninchen & $1: 50$ \\
\hline SOX9 & Mensch & monoclonal & Maus & $1: 50$ \\
\hline RUNX2 & Maus & polyclonal & Kaninchen & $1: 20$ \\
\hline Dekorin & Mensch & monoclonal & Maus & $1: 20$ \\
\hline Osteopontin & Mensch & monoclonal & Maus & $1: 20$ \\
\hline
\end{tabular}

Tabelle 8: Immunzytochemie: sekundäre Antikörper

\begin{tabular}{cccc}
\hline Name & $\begin{array}{c}\text { Firma/Num- } \\
\text { mer }\end{array}$ & Herkunft & Verdünnung \\
\hline $\begin{array}{c}\text { Donkey Anti-Rabbit } \\
\text { IgG, Alexa Fluor 555 }\end{array}$ & $\begin{array}{c}\text { Abcam, ab } \\
150074\end{array}$ & $\begin{array}{c}\text { Esel, gegen } \\
\text { Kaninchen; poly- } \\
\text { clonal }\end{array}$ & $1: 1000$ \\
\hline $\begin{array}{c}\text { Goat Anti-Mouse IgG, } \\
\text { Alexa Fluor 555 }\end{array}$ & $\begin{array}{c}\text { Abcam, ab } \\
150114\end{array}$ & $\begin{array}{c}\text { Ziege, gegen } \\
\text { Maus; polyclonal }\end{array}$ & $1: 1000$ \\
\hline
\end{tabular}

\subsection{Western Blot}

\subsubsection{Allgemeines zum Western Blot}

Der Western Blot ist ein biochemisches Verfahren, dass dem Nachweis von Proteinen dient, indem diese Proteine zunächst nach ihrer molekularen Masse aufgetrennt und anschließend nach erfolgter Übertragung auf eine Membran durch eine Immunreaktion bestimmt werden. Zunächst wird dafür ein Proteingemisch in der 
Gelelektrophorese auf ein Polyacrylamidgel mit SDS-Zusatz gegeben und ein elektrisches Feld angelegt. Aufgrund ihrer Ladung bewegen sich die Proteine senkrecht entlang des Gels zur Anode, und es entstehen Proteinbanden.

Anschließend erfolgt das eigentliche Blotting, indem das Gel direkt auf eine Polyvinylidenfluorid- (PVDF-) Membran gelegt wird und erneut ein elektrisches Feld angelegt wird. Die Proteine wandern nun ebenfalls senkrecht zur Anode und bleiben aufgrund polarer Wechselwirkungen auf der Membran haften. Die Proteinbanden können anschließend mit einer Coomassie-Färbung sichbar gemacht werden, und spezifische Proteine anhand ihrer Bandenhöhe und deren Höhenvergleich zur Markerproteinbande bestimmt werden. Für diesen Nachweis erfolgt eine Immunreaktion durch das Hinzugeben eines primären AK, welches spezifisch an das nachzuweisende Protein bindet. Ein sekundärer Ak bindet wiederrum an die Fc-Region des primären Antikörpers und katalysiert durch die Umsetzung eines Substrates eine Chemilumineszenzreaktion, welche fluoresziert. Die Fluoreszenz wird in einem Blotscanner detektiert und anschließend ausgewertet.

\subsubsection{Proteinprobenvorbereitung}

Zur Vorbereitung der Proteinproben wurden die Zellen kultiviert und, wie unter 2.2 beschrieben, bei ausreichender Konfluenz geerntet. Pro Probentasche wurden in unserem Fall $2,5 \times 10^{5}$ Zellen verwendet, weshalb generell $1 \times 10^{6}$ als standardisierte Menge bis zur Verwendung bei $-80{ }^{\circ} \mathrm{C}$ tiefgefroren wurden. Zunächst ist ein Heizblock (Thermocycler comfort, Eppendorf, Hamburg, D) auf $95^{\circ} \mathrm{C}$ erhitzt worden und ein Probenpuffer angemischt, der aus 3x SDS-Probenpuffer und ß-Mercaptoethanol (Sigma-Aldrich, Steinheim, D) besteht. Der Anteil an ß-Mercaptoethanol an dem Gemisch betrug immer $10 \%$, für einen Milliliter ergab sich damit eine Mischung von $900 \mu \mathrm{l} 3 x$ SDS-Probenpuffer und $100 \mu \mathrm{l}$ ß-Mercaptoethanol. Pro 2,5×105 Zellen wurden $25 \mu$ des Probenpuffers zu dem Zellpellet hinzugegeben und dieses resuspendiert. Das gesamte E-Cup wurde dann für 5 Minuten bei $95^{\circ} \mathrm{C}$ im Heizblock erhitzt und die Lyse-Mischung anschließend direkt in die Probentaschen der vorbereiteten SDS-Gelelektrophorese pipettiert. 


\author{
3x SDS-Probenpuffer $\quad 3,6 \mathrm{~g} \quad$ 0,3 M Tris (Roth, Karlsruhe, D) \\ $9 \mathrm{~g} \quad 9 \%$ SDS (Roth, Karlsruhe, D) \\ 22,5 g 22,5 \% Glycerin (Roth, Karlsruhe, D) \\ Spatelspitze Bromphenolblau dazugeben \\ Mit HCL auf pH 6,7 einstellen \\ Mit $\mathrm{H}_{2} \mathrm{O}$ auf $100 \mathrm{ml}$ auffüllen \\ Bei RT oder $-20^{\circ} \mathrm{C}$ für einen längeren Zeitraum
}

\title{
2.8.3 Natriumdodecylsulfat-Polyacrylamidgelelektrophorese
}

Zur Herstellung der Polyacrylamid-Gele erfolgte zunächst die Reinigung von zwei Glasplatten mit 100\% Ethanol, um sämtliche, noch vorhandenen Gelreste zu entfernen. Es wurde eine Gummidichtung ringsherum auf der Platte mit Spacern angebracht und eine Ohrenplatte daraufgelegt. Die beiden Platten wurden mit zwei Klammern befestigt, sodass kein Spalt zwischen den Glasplatten und der Gummidichtung vorhanden war und die gesamte Konstruktion aufrecht auf dem Arbeitstisch stehen konnte. Es wurde anschließend eine Edding-Markierung $6 \mathrm{~cm}$ oberhalb des unteren Glasrandes angebracht, welche die Höhe angab, bis zu der das Trenngel gegossen werden sollte. Nun wurden alle unten aufgelisteten Bestandteile des Trenngels in ein Glasgefäß pipettiert und vorsichtig vermischt. Es war hier darauf zu achten, dass die 0,5 ml 10 \% APS im letzten Schritt dazugegeben wurde, da der Polimerisationsvorgang hiernach beschleunigt ablief. Das Gel wurde bis zur vorher angebrachten Markierung gegossen und dann mit ca. $1 \mathrm{ml} 100 \%$ Ethanol bedeckt, um eine mögliche Luftblasenbildung zu vermeiden. Nach ca. 15 Minuten war das Trenngel vollständig auspolimerisiert, und das Ethanol konnte abgekippt werden. Die gelisteten Sammelgelbestandteile wurden zusammenpipettiert und nach gründlichem Vermischen auf die erste Phase gegossen. Umgehend war ein Plastikkamm einzusetzen, der den Platz für die späteren Probentaschen der Proteinlösungen freihielt. Nachdem auch diese Phase vollständig auspolimerisiert war, wurden der Plastikkamm, die Halteklammern und die Gummidichtung entfernt, und das fertige Gel konnte bis zu zwei Wochen in feuchtem Papier bei $-4{ }^{\circ} \mathrm{C}$ im Kühlschrank gelagert werden. 
Für die Durchführung der Gelelektrophorese wurde der Nachbau einer Biometra Elektrophoresekammer verwendet. Die Kammern wurden zunächst zur Hälfte mit 1X Laufpuffer befüllt und eine Glasplatte mit dem Gel vorsichtig hineingestellt. Dabei war darauf zu achten, dass es zu keiner Luftblasenbildung unterhalb des Gels kam. Die Glasplatte wurde mit zwei Klammern befestigt und die Kammern vollständig mit 1X Laufpuffer aufgefüllt. Der Proteinleiter (Fermentas, \#SM0671) und die Proben konnten nun in die Probentaschen pipettiert werden, wobei wir bevorzugt die erste und letzte Tasche freigelassen haben. Von dem Proteinleiter wurden jeweils $4 \mu \mathrm{L}$ pro Tasche pipettiert und $25 \mu \mathrm{L}$ von den vorbereiteten Proben aufgetragen. Das Auftragen des Proteinleiters diente später zur Auswertung der Blot-Ergebnisse, da mit seiner Hilfe das genaue Molekulargewicht der Proteine abgelesen werden konnte.

Zunächst wurde eine Stromspannung von 10-15 mA pro Gel angelegt, welche nach Erreichen der Trenngelkante auf 20-15 mA hochgestellt wurde. Sobald die komplette Proteinleiter auf dem Gel zu sehen war, wurde die Gelelektrophorese beendet.

Tabelle 9: Trenngel (für 2 Gele)

\begin{tabular}{cc}
\hline & $10 \%$ \\
\hline Trenngelpuffer & $2,8 \mathrm{ml}$ \\
\hline $10 \%$ SDS & $110 \mu \mathrm{l}$ \\
\hline TEMED & $10 \mu \mathrm{l}$ \\
\hline Acrylamid & $3,7 \mathrm{ml}$ \\
$\mathrm{H}_{2} \mathrm{O}$ & $4 \mathrm{ml}$ \\
\hline
\end{tabular}

Mischen + 0,5 $\mathrm{ml} 10 \%$ APS 
Tabelle 10: Sammelgel (für 2 Gele)

\begin{tabular}{cc}
\hline & $\mathbf{5 \%}$ \\
\hline Sammelgelpuffer & $1,25 \mathrm{ml}$ \\
\hline $\mathbf{1 0} \%$ SDS & $50 \mu \mathrm{l}$ \\
\hline TEMED & $5 \mu \mathrm{l}$ \\
\hline Acrylamid & $0,8 \mathrm{ml}$ \\
\hline $\mathrm{H}_{2} \mathrm{O}$ & $2,7 \mathrm{ml}$ \\
\hline
\end{tabular}

Mischen + 0,2 $\mathrm{ml} 10 \%$ APS

Trenngelpuffer

1,5 M Tris (MG 121,4) 45,4g

Mit $\mathrm{H}_{2} \mathrm{O}$ auf $250 \mathrm{ml}$ auffüllen

Mit HCL auf pH 8,9 einstellen

Sammelgelpuffer

0,5 M Tris (MG 121,14) 15,1g

Mit $\mathrm{H}_{\mathrm{s}} \mathrm{O}$ auf $250 \mathrm{ml}$ auffüllen

Mit HCL auf $\mathrm{pH}$ 6,8 einstellen

5X SDS Laufpuffer

30,3 g 0,25 M Tris

142,6 g 1,9 M Glycin

0,5 \% SDS (50 ml $10 \%$ SDS)

mit $\mathrm{H}_{2} \mathrm{O}$ auf 1000 ml auffüllen

\subsubsection{Versuchsdurchführung}

Bevor mit dem Bau der Blot-Kassette begonnen wurde, wwaren einige vorbereitenden Schritte durchzuführen. Pro Blot wurden 6 Filterpapiere, 2 Schwämme und 1 PVDF-Membran benötigt. Die Filterpapiere und die Transfermembran wurden vorher so zugeschnitten, dass sie das Gel um wenige Millimeter überragten und somit das komplette Proteinspektrum auf die Membran übertragen werden konnte. Nun war es wichtig, dass die Transfermembran durch 15-sekündiges Schwenken in 
$100 \%$ Methanol aktiviert wurde. Anschließend wurde eine Kiste mit 1x Transferpuffer befüllt und die Schwämme, Filterpapiere und die Membran für mindestens 15 Minuten darin eingeweicht. Bei dem Zusammenbau des Gelsandwichs war folgende Reihenfolge zu beachten. Die rote Seite der Blot-Kassette lag unten, darauf folgte ein Schwamm sowie 3 Filterpapiere. Nun wurde die aktivierte PVDF-Membran vorsichtig daraufgelegt und das fertige Gel luftblasenfrei auf der Membran plaziert. Dieser Schritt war mit Vorsicht durchzuführen, da es bei dem Bewegen des Gels zu Rissen kommen konnte und eine Lustblasenbildung zu vermeiden war. Folgend wurden 3 weitere Filterpapiere und ein Schwamm daraufgelegt und die Blot-Kassette mit zwei Gummibändern fixiert. Entsprechend der Farbkodierung ist die Kassette in den mit Transferpuffer gefüllten Puffertank eingesetzt worden. Nach Einschalten der Wasserkühlung wanderten die Proteine bei 350 mA für 90 min in Richtung der Anode auf die PVDF-Membran.

$\begin{array}{ll}\text { Transfer-Puffer } \quad & 25 \mathrm{mM} \text { Tris } \quad 6,05 \mathrm{~g} \\ & 192 \mathrm{mM} \text { Glycine } 28,8 \mathrm{~g} \\ & 20 \% \text { Methanol } 400 \mathrm{ml} \\ & \text { mit dest. Wasser auf } 2 \text { Liter auffülle, } \mathrm{pH} 8,3\end{array}$

\subsubsection{Proteindetektion}

Zum Anfärben der Proteinbanden auf der PVDF-Membran wurde eine 0,1\% Coomassie-brilliant-blau-Lösung (Roth, Karlsruhe, D) verwendet. Die Färbung wurde zur Membran in eine kleine Schale gegeben und darin für 2-10 min auf einem Schwenktisch bis zur vollständigen Färbung belassen. Anschließend erfolgte die Behandlung der PVDF-Membran mit einer Entfärberlösung, um den Hintergrund zu entfärben. Die Lösung, bestehend aus Methanol und Essigsäure, wurde danach weggekippt und verbliebene Reste zweimal für 5 min mit TBS-T weggewaschen. Daraufhin konnte die Membran eingescannt und die Scanbilder zu Dokumentationszwecken aufbewahrt werden. 
Coomassie-brilliant-blau

Entfärberlösung

\author{
$0,1 \mathrm{~g}$ Coomassie brilliant blue $\mathrm{R}$ \\ $50 \mathrm{ml} 100 \%$ Methanol \\ $7 \mathrm{ml} 100 \%$ Essigsäure \\ mit Wasser auf $100 \mathrm{ml}$ auffüllen
}

\author{
$50 \mathrm{ml} 100 \%$ Methanol \\ $7 \mathrm{ml} 100 \%$ Essigsäure \\ mit Wasser auf $100 \mathrm{ml}$ auffüllen
}

\subsubsection{Immunmarkierung}

Nach dem Entnehmen der PVDF-Membran aus der Kassette wurde die Membran für 1 Stunde bei Raumtemperatur mit einer 5\% Blocklösung, bestehend aus Milchpulver (Roth, Karlsruhe, D) und TBS-T, geblockt. Hierdurch wurden unspezifische Proteinbindungsstellen gebunden und eine ungewollte Bindung der Antikörper an diesen Stellen verhindert. Anschließend wurden die primären Antikörper der nachzuweisenden Proteine, nach der vom Hersteller vorgegebenen Konzentration in der Blocklösung verdünnt und in der Schale auf die Membran pipettiert. Es erfolgte eine Inkubation des Versuchsansatzes bei $4{ }^{\circ} \mathrm{C}$ über Nacht im Kühlraum, auf einem Schwenktisch. Nach erfolgter Inkubation wurde die Membran 5X5 min mit TBS-T gewaschen. Je nachdem, aus welchem Wirt der primäre Antikörper stammt, wurde der entsprechende sekundäre Antikörper gewählt und ebenfalls in der Blocklösung auf die gewollte Konzentration verdünnt. Nachdem die Membran für $1 \mathrm{~h}$ mit dem sekundären Antikörper inkubiert wurde, ist sie erneut 5X5 min mit TBS-T gewaschen worden.

Anschließend erfolgte die Detektion des Proteins entweder mit dem Western Bright (Advansta) ECL oder dem stärkeren Sirius. Wobei jeweils die Lösungen A und B in einem Mengenverhältnis von 1:1 gemischt und für 5 min auf die Membran gegeben wurden. Die Reaktion erfolgte lichtgeschützt und löste eine chemolumineszierende Wirkung aus. Davor war es wichtig, die Markerbanden mit einem Blotstift zu markieren. Die Membran wurde anschließend in den C-Digit-Blotscanner (Li-Cor) eingelegt und gescannt. Das Blotergebnis konnte auf dem angeschlossenen PC zur Ansicht wiedergegeben werden. Anhand der Bandenhöhe des gesuchten Proteins 
und deren Relation zur Proteinleiter des Markers, konnte das Molekulargewicht des Proteins abgelesen werden. Für jedes nachzuweisende Protein wurden drei verschiedene Blotnachweise erbracht, wobei diese quantitativ miteinander verglichen wurden und damit die Signifikanz überprüft wurde.

\subsubsection{Verwendete Antikörper im Western Blot}

Tabelle 11: Western Blot: primäre Antikörper

\begin{tabular}{cccc}
\hline Name & Firma/Nummer & Herkunft & Verdünnung \\
\hline Kollagen I & Acris, A120083H & Kaninchen & $1: 1000$ \\
\hline Runx2 & $\begin{array}{c}\text { Cell Signaling, } \\
\text { \#8486 }\end{array}$ & Kaninchen & $1: 500$ \\
Sox9 & Acris, CJ36131 & Kaninchen & $1: 1000$ \\
\hline
\end{tabular}

Tabelle 12: Western Blot: sekundäre Antikörper

\begin{tabular}{cccc}
\hline Name & Firma/Nummer & Herkunft & Verdünnung \\
\hline Anti-Rabbit IgG & Sigma, A0545 & $\begin{array}{c}\text { Ziege, Anti-Kanin- } \\
\text { chen, Peroxidase } \\
\text { gekoppelt }\end{array}$ & $1: 100000$ \\
& & $\begin{array}{c}\text { gek } \\
\text { chen }\end{array}$ &
\end{tabular}

Tabelle 13: Antikörper der Ladungskontrolle

\begin{tabular}{cccc}
\hline Name & Firma/Nummer & Herkunft & Verdünnung \\
\hline GAPDH & Abcam, 9484 & Maus & $1: 10000$ \\
\hline
\end{tabular}

\subsubsection{Auswertung der Western Blots}

Die Western Blots wurden mit Hilfe von Exel durch die Berechnung unterschiedlicher Quotienten ausgewertet. Zunächst wurde der Quotient aus Zielprotein und Ladungskontrolle (GAPDH) gebildet, anschließend der Quotient aus relativer Dichte der Probe und der Kontrolle. Durch diese Berechnungen wurde das relative Proteinlevel der abgebildeten Bande berechnet. Die Signifikanz der Ergebnisse wurden auf 
vassarstats. net geprüft, dabei wurde sie wie folgt festgelegt: $P={ }^{*}<0,05, P={ }^{* *}<0,01$, $P=* * *<0,001$.

\subsubsection{Strippen der PVDF-Membran}

Um nach Benutzung der PVDF-Membran einen weiteren Proteinnachweis durchzuführen, ist es möglich die bereits erfolgte Proteinbindung wieder zu entfernen und die Membran mehrmals zu verwenden. Hierfür wurde ein Wasserbad auf $65^{\circ} \mathrm{C}$ vorgeheizt und die Membran anschließend für 15 min in einem Stripping-Puffer in dem beheizten Bad gewaschen. Diese wurde danach 2X10 min bei Raumtemperatur mit TBS-T gewaschen. Um eine erneute Immunreaktion durchzuführen wurde die Membran erneut $1 \mathrm{~h}$ mit $5 \%$ Blocklösung geblockt.

\subsection{Durchflusszytometrie}

\subsubsection{Allgemeines zur Durchflusszytometrie (FACS-Analyse)}

Die Durchflusszytometrie beschreibt ein Verfahren, dass es ermöglicht spezifische Zelloberflächenantigene sowie intrazelluläre Antigene durch die Markierung mit fluoreszierenden Antikörpern nachzuweisen. Hierzu werden die markierten Zellen in einem sogenannten Durchflusszytometer durch einen Laserstrahl geführt und das dabei entstehende Fluoreszenzsignal detektiert. Die Menge dieses Signals wird anschließend prozentual zur Zellmenge ausgewertet und dargestellt. Für diese Studie erfolgte lediglich der Nachweis intrazellulärer Antikörper, wobei zunächst eine für die verwendete Zellgruppe spezifische Maske erstellt wurde, anhand derer ein Ablesen der prozentualen Menge GFP- positiver, Antikörper-positiver sowie doppelt positiver und negativer Zellen aus der Gesamtmenge möglich war.

\subsubsection{Versuchsdurchführung}

Die kultivierten Osteoblasten wurden wie bereits beschrieben geerntet und jeweils $3 \times 10^{5}$ Zellen zusammen mit $1 \mathrm{ml}$ PBS in ein Reagenzflächen pipettiert. Anschließend wurden sie bei 300 xg für 5 min zentrifugiert und der Überstand weggekippt. 
Daraufhin wurden $100 \mu \mathrm{L}$ von Reagenz A (Fix\&Perm, cell permeabilization Kit, invitrogen) hinzugegeben und das Zellpellet resuspendiert. Es erfolgte eine 15-minütige Inkubation bei Raumtemperatur im Dunkeln.

Anschließend wurde das Zellgemisch einmal mit $3 \mathrm{ml}$ einer 5\% Waschlösung, bestehend aus $5 \%$ fetalem Kälberserum und PBS, für 5 min gewaschen und der Überstand nach erneutem zentrifugieren abgekippt. Nun erfolgte die Zugabe von $100 \mu \mathrm{l}$ Reagenz B und $2 \mu$ des primären Antikörpers. Nach einer einstündigen Inkubation bei Raumtemperatur im Dunkeln wurde erneut mit $3 \mathrm{ml}$ der Waschlösung gewaschen und der Überstand verworfen. Es wurde die gleiche Menge des entsprechenden sekundären Antikörpers hinzugegeben und nach 30-minütiger Inkubation erneut gewaschen. Das Zellpellet wurde nach dem Zentrifugieren mit $300 \mu \mathrm{l}$ reinem PBS resuspendiert und konnte anschließend im Zytometer ausgewertet werden.

\subsubsection{Verwendete Antikörper in der FACS-Analyse}

Tabelle 14: FACS-Analyse: primäre Antikörper

\begin{tabular}{cccc}
\hline Name & Firma/Nummer & Herkunft & Menge $(\mu \mathrm{L})$ \\
\hline Kollagen I & Acris, A120083H & Kaninchen & 2 \\
\hline Sox9 & Abnova, 12234- & Maus & 2 \\
Runx2 & Cell Signaling, & Kaninchen & 2 \\
& $\# 8486$ & Maus & 2 \\
\hline
\end{tabular}

Tabelle 15: FACS-Analyse: sekundäre Antikörper

\begin{tabular}{cccc}
\hline Name & Firma/Nummer & Herkunft & Menge $(\mu \mathrm{L})$ \\
\hline Anti-Mouse IgG & Abcam, ab150114 & $\begin{array}{c}\text { Ziege, Anti-Maus, } \\
\text { Alexa Fluor 555 }\end{array}$ & 2 \\
\hline \multirow{2}{*}{ Anti-Rabbit IgG } & Abcam, ab150074 & $\begin{array}{c}\text { Esel, Anti-Rabbit, } \\
\text { Alexa Fluor 555 }\end{array}$ & 2 \\
\hline
\end{tabular}




\subsubsection{Auswertung der FACS-Analyse}

Zur Auswertung der prozentualen Ergebnisse, wurden diese jeweils in Exel übertragen, und eine Standardabweichung sowie ein Mittelwert aller Ergebnisse gebildet. Diese Werte wurden anschließend in Diagrammform dargestellt. Alle Versuche wurden dreimal durchgeführt, um sicherzugehen, dass die Ergebnisse reproduzierbar waren und keinen starken Schwankungen unterlagen. Als Negativkontrolle wurde jeweils ein Zellpellet mit den verwendeten sekundären AK inkubiert, um nachzuweisen, dass keine unspezifischen Bindungen vorkommen. Die Signifikanz der Ergebnisse wurden auf vassarstats.net geprüft. 


\section{Ergebnisse}

Im Folgenden werden die Nachweisreaktionen der bereits genannten Markerproteine auf mRNA- sowie auf Proteinebene dargestellt und erläutert. Des Weiteren erfolgt eine Darstellung der Immunfluoreszenzfärbungen und der Analysen der Durchflusszytometrie (FACS). Dabei wurden sämtliche Versuche mit undifferenzierten, immortalisierten osteoblastären Zellen durchgeführt, die aus dem humanen Alveolarknochen stammen. Einige Nachweise erfolgten außerdem nach zweiwöchiger Differenzierung der Zellen in einem osteogenen Medium. 


\subsection{Lichtmikroskopische Bilder osteoblastärer Zellen}

Zur deutlichen Darstellung der Osteoblasten vor erfolgter osteogener Differenzierung wurden diese in einer Übersicht- sowie Detailaufnahme fotografiert. Dies erfolgte nach Kultivierung der Zellen bis zu leichter Konfluenz, um eine möglichst korrekte Abbildung der Zellgruppen zu ermöglichen. Es lässt sich eine gruppenbildende Tendenz der Osteoblasten erkennen, wobei diese nicht so stark ausgeprägt ist, wie bei anderen Zellgruppen. In der Detailaufnahme sind der Zellkern, sekretorische Vesikel, ebenso wie viele zytoplasmatische Ausläufer zu erkennen. Über diese stehen sie mit weiteren Knochenzellen in Verbindung. Deutlich ist die Ähnlichkeit zu Fibroblasten erkennbar, welche ebenfalls schlanke Ausläufer besitzen.
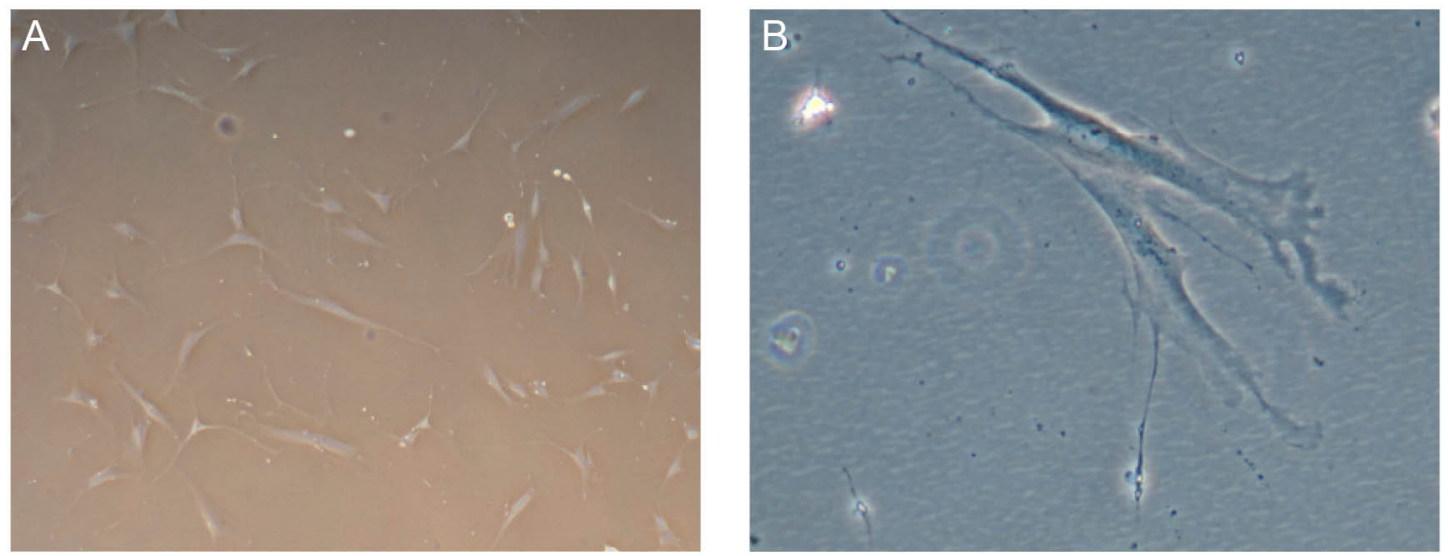

Abbildung 1: Lichtmikroskopische Übersicht- und Detailaufnahme osteoblastärer Zellen

A: Übersichtaufnahme einer Zellansammlung nach Kultivierung über mehrere Tage, 5-fach vergrößert. B: Detailaufnahme eines einzelnen Osteoblasten, 20-fach vergrößert. 


\subsection{Nachweis der Immortalisierung}

Der Nachweis der erfolgreichen Immortalisierung der osteoblastären Zellen erfolgte, bevor mit den weiteren Versuchen begonnen wurde. In der Abbildung 2 ist von links nach rechts der erfolgreiche Einbau von hTERT in chondrogene Progenitorzellen (CPC`s), Osteoblasten (OB`s) und Zementoblasten (ZB`s) abzulesen, identifizierbar durch seine eindeutige Höhe auf der DNA-Leiter. Da die Immortalisierung von humanen Osteoblasten aus dem Alveolarknochen noch nie zuvor dokumentiert wurde, dienen die CPC's als Kontrolle.

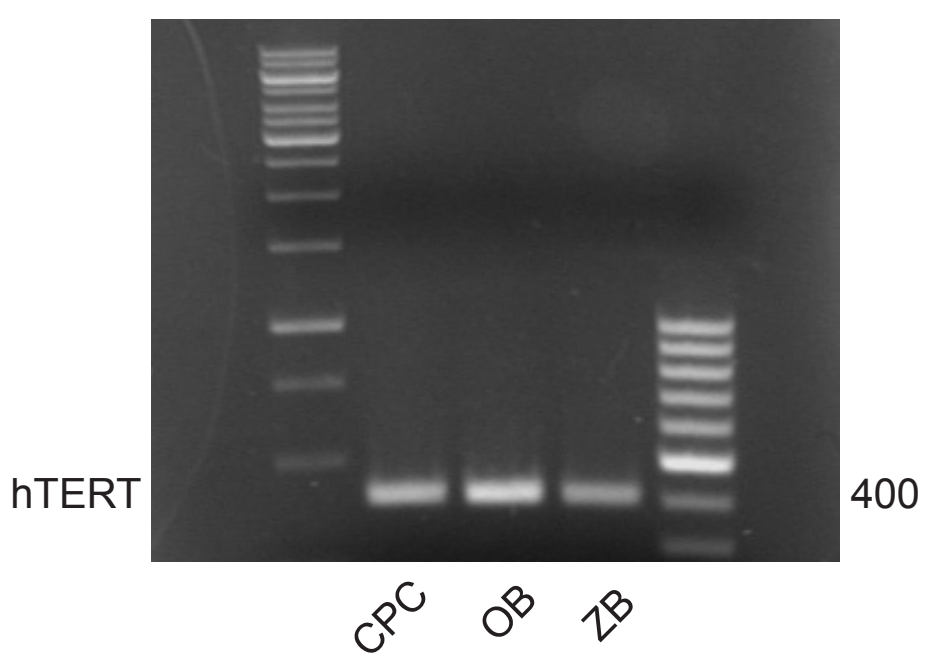

\footnotetext{
Abbildung 2: Nachweis der Immortalisierung osteoblastärer Zellen im Agarosegel
}

Von links nach rechts ist der Einbau des Primers hTERT in chondrogenen Progenitorzellen, Osteoblasten und Zementoblasten auf einer Basenpaarhöhe von ca. 420 im Agarosegel abzulesen.

Abbildung 2 ist ebenfalls dargestellt in der Doktorarbeit „Gewinnung und Charakterisierung von humanen Zementoblasten“ von Katharina Bernhardt. 


\subsection{Quantitative Auswertung der Echtzeit-PCR}

In Abbildung 3 erfolgt die grafische Darstellung der Expressionsnachweise verschiedener kollagener sowie nicht-kollagener Markerproteine osteoblastärer Zellen und eines Transriptionsfaktors der chondrogenen Zelllinie, Sox9. Ebenfalls nachgewiesen werden konnte CP-23, ein Protein, dass bisher als Zementoblasten- und PDL-spezifisch galt. Der Nachweis erfolgte auf mRNA-Ebene und wurde statistisch mittels Pfaffl ausgewertet, indem Zementoblasten als Kontrolle dienten. Hierbei ist vor allem die starke Expression von Sox9 erkennbar, vor allem im Vergleich mit der geringen Expression von Runx2. Ebenfalls abzulesen, ist die gegenüber Kollagen I erhöhte Expression von Kollagen III.

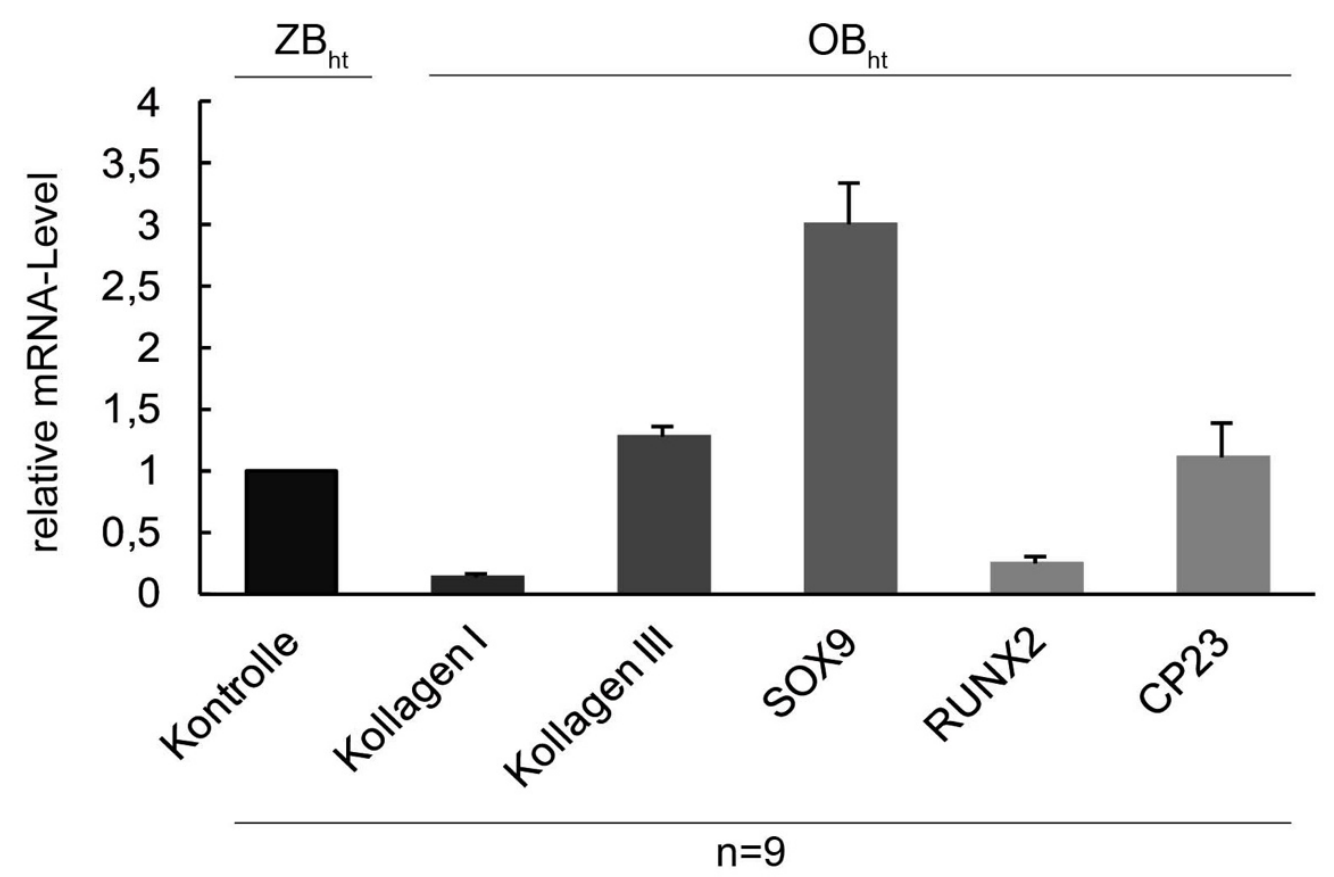

\section{Abbildung 3: Quantitative Auswertung des relativen mRNA-Levels der Marker- proteine Kollagen I, Kollagen III, SOX9, RUNX2, CP-23}

Dargestellt werden in Abbildung 3 die Expressionsnachweise verschiedener osteogener Markerproteine, sowie Sox9 und CP-23. Die Balken stellen die Mittelwerte \pm Standardabweichung im Vergleich zur Kontrolle (festgesetzt als 1, Zementoblasten), wobei die Nummer der Replikate $\mathrm{n}$ ist. 
In Abbildung 4 erfolgt die grafische Darstellung der Expressionsnachweise von Bone Sialoprotein und Vegf sowie der PG`s Dekorin und Versikan. Osteocalcin, ein als Osteoblasten-spezifisch geltendes Protein, wurde ebenfalls nachgewiesen. Erkennbar ist die starke mRNA-Expression von Versikan gegenüber den anderen osteogenen Markern, besonders Dekorin.

Der Nachweis erfolgte auf mRNA-Ebene und wurde statistisch mittels Pfaffl ausgewertet, indem Zementoblasten als Kontrolle dienten.

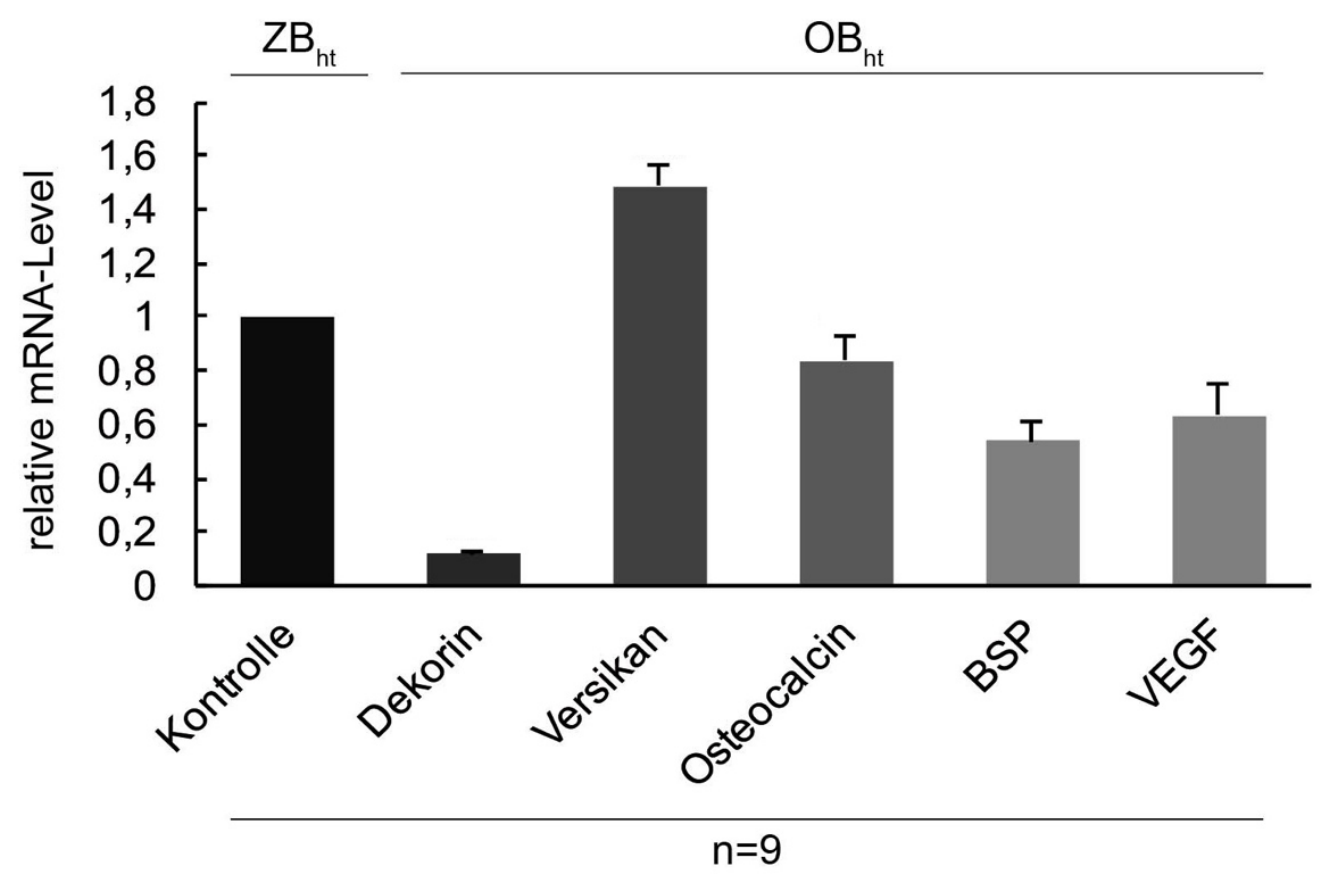

\section{Abbildung 4: Quantitative Auswertung des relativen mRNA-Levels der Marker- proteine Dekorin, Versikan, Osteocalcin, BSP, VEGF}

Dargestellt werden in Abbildung 4 die Expressionsnachweise verschiedener osteogener Markerproteine. Die Balken stellen die Mittelwerte \pm Standardabweichung im Vergleich zur Kontrolle (festgesetzt als 1, Zementoblasten), wobei die Nummer der Replikate $\mathrm{n}$ ist.

Außer den oben genannten Proteinen wurde die qRT-PCR zum Nachweis von Sclerostin, der alkalischen Phosphatase und RANKL durchgeführt. Es konnte alleinig 
ein Nachweis der alkalischen Phosphatase erfolgen, die osteoblastären Zellen zeigten keine Expression von Sclerostin und von RANKL auf mRNA-Ebene. Es ist uns allerdings keine statistische Auswertung der ALP-Expression möglich, da die Kontrollzellen keine Expression zeigten.

\subsection{Lichtmikroskopische Bilder osteogen differenzierter Zellen}

Zur deutlichen Darstellung der Osteoblasten nach erfolgter osteogener Differenzierung, wurden diese in einer Übersicht- sowie Detailaufnahme fotografiert. Dies erfolgte nach Kultivierung der Zellen bis zu leichter Konfluenz, um eine möglichst korrekte Abbildung der Zellgruppen zu ermöglichen. Es lässt sich eine gruppenbildende Tendenz der Osteoblasten erkennen, wobei sie weniger stark ausgebildet ist, als zuvor. In der Detailaufnahme sind der Zellkern, sekretorische Vesikel, ebenso wie viele zytoplasmatische Ausläufer zu erkennen, wobei der Zellkörper breiter als zuvor ist und mehr zytoplasmatische Ausläufer besitzt.
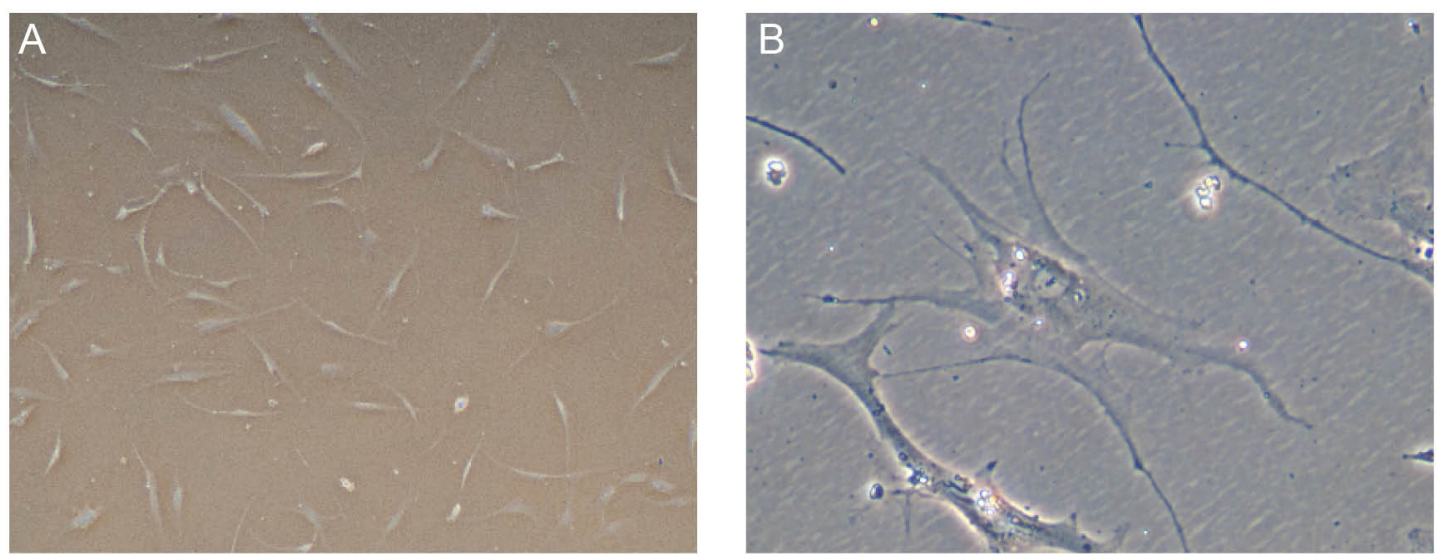

\section{Abbildung 5: Lichtmikroskopische Übersicht- und Detailaufnahme osteogen differenzierter Zellen}

A: Übersichtaufnahme einer Ansammlung von 2-wöchig osteogen differenzierten Zellen, 5-fach vergrößert; B: Detailaufnahme einer einzelnen osteogen differenzierten Zelle, 20-fach vergrößert. 


\subsection{Quantitative Echtzeit-PCR osteogen differenzierter Zellen}

In Abbildung 6 erfolgt die grafische Darstellung der Expressionsnachweise von CP23 nach osteogener Differenzierung im Vergleich zur Kontrolle, den undifferenzierten osteoblastären Zellen. Sichtbar ist eine verringerte mRNA-Expression nach der Differenzierung. Ebenfalls dargestellt, wird die Expression von Osteocalcin nach erfolgter osteogener Differenzierung im Vergleich zur Kontrolle, den undifferenzierten osteoblastären Zellen. Eine mehr als dreifach erhöhte Expression von Osteocalcin ist nach der Differenzierung abzulesen.

Der Nachweis erfolgte auf mRNA-Ebene und wurde statistisch mittels Pfaffl ausgewertet, indem undifferenzierte Osteoblasten als Kontrolle dienten.

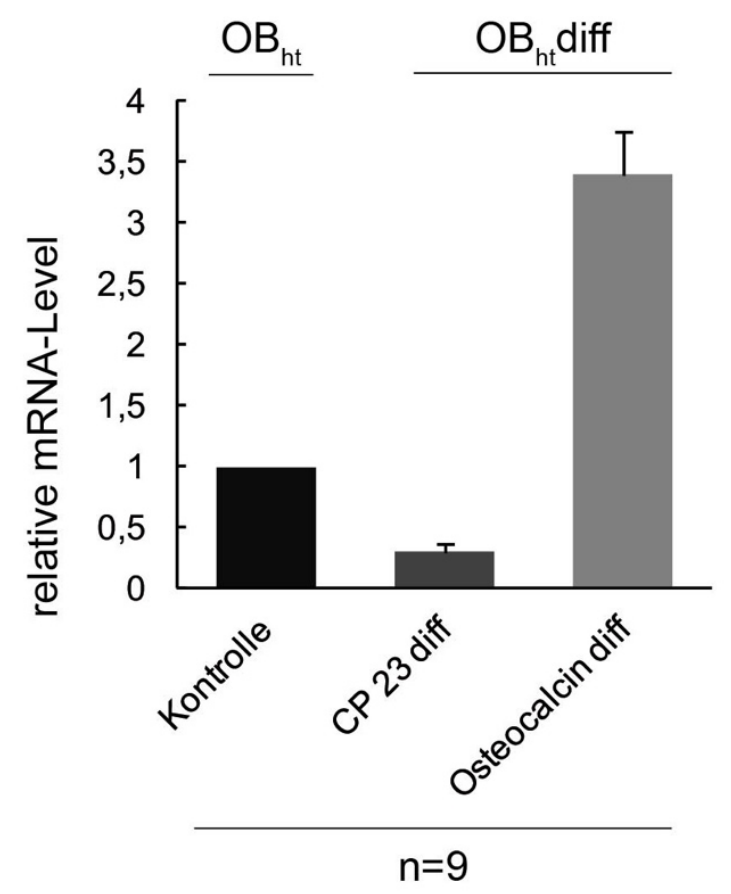

\section{Abbildung 6: Quantitative Auswertung des relativen mRNA-Levels der Marker- proteine CP-23, Osteocalcin und ALP nach osteogener Differenzierung}

Dargestellt werden in Abbildung 6 die Expressionsnachweise von CP-23 sowie Osteocalcin nach osteogener Differenzierung. Die Balken stellen die Mittelwerte \pm Standardabweichung im Vergleich zur Kontrolle (festgesetzt als 1, undifferenzierte Osteoblasten), wobei die Nummer der Replikate $\mathrm{n}$ ist. 


\subsection{Nachweis von Kollagen I im Western Blot}

In Abbildung 7 erfolgt die bildliche sowie grafische Darstellung des Nachweises von Kollagen I im Western Blot. Links ist ein Scan der entsprechenden Coomassie-Färbung der Proteinbanden abgebildet, wobei von links nach rechts zunächst CPC`s, ZB`s und OB`s aufgetragen wurden. Mittig ist der Nachweis von Kollagen I bei einem Molekulargewicht von ca. 150 kDA und der Ladungskontrolle GAPDH bei ca. 40 kDA. In Abb7C erfolgt die grafische Darstellung der Proteinexpression von Kollagen I im Vergleich zur Kontrolle, den CPC's.
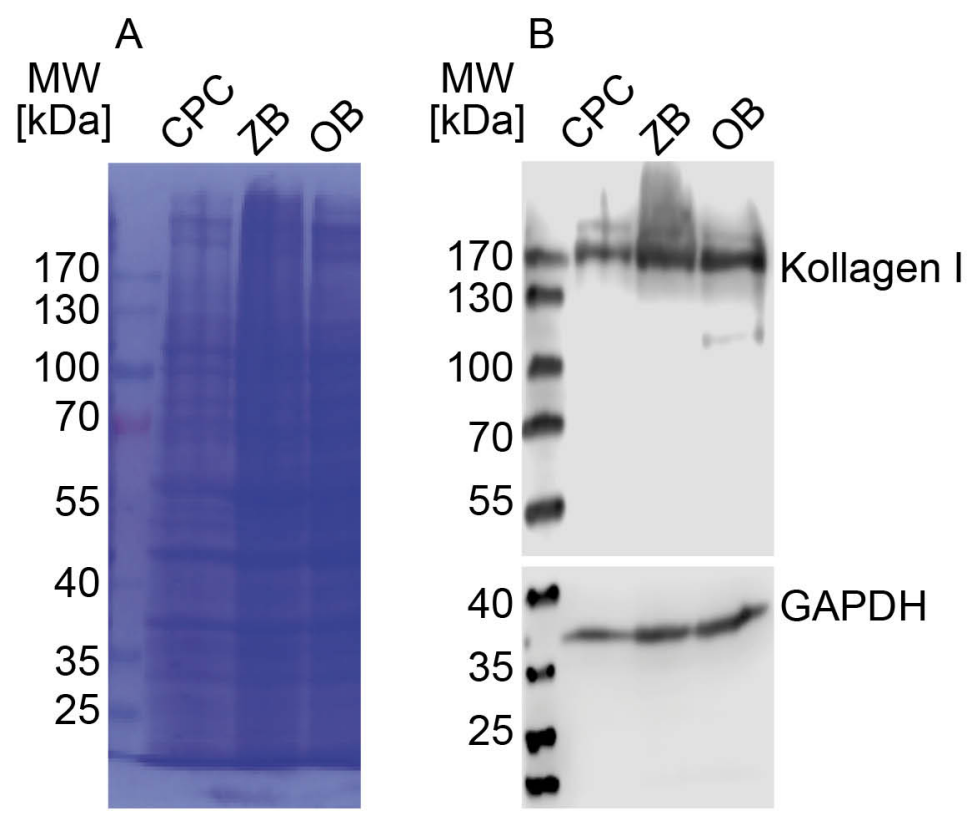

C

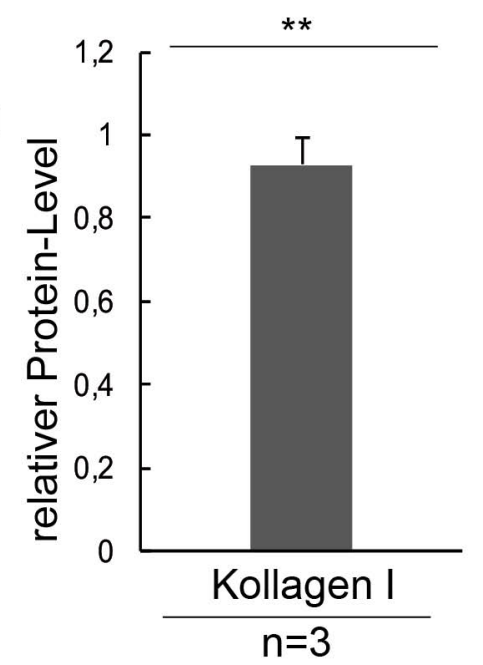

\section{Abbildung 7: Proteinnachweis von Kollagen I}

A: Coomassie-Färbung des Western Blots. B: Proteinnachweis von Kollagen I bei dem Molekulargewicht von ca. 150 kDA und einer AK-Verdünnung von 1:1000 sowie von GAPDH bei einem Molekulargewicht von ca. 40 kDA und einer AK-Verdünnung von 1:10000. GAPDH dient als Housekeeping-Gen zur Ladungskontrolle. C: Quantitative Auswertung der Proteinlevels von Kollagen I im Vergleich zur Kontrolle. Der Balken stellt den Mittelwert \pm Standardabweichung im Vergleich zur Kontrolle (festgesetzt als 1, CPC`s) von drei getrennten Durchläufen $(n=3)$ dar. Dabei wurde die Standardabweichung wie folgt festgelegt: ** $<0,01$. Die Markierung 1 auf der $y-$ Achse der grafischen Darstellung entspricht dem Kontrollwert. 


\subsection{Nachweis von Runx2 im Western Blot}

In Abbildung 8 erfolgt die bildliche sowie grafische Darstellung des Nachweises von Runx2 im Western Blot. Links ist ein Scan der entsprechenden Coomassie-Färbung der Proteinbanden abgebildet, wobei von links nach rechts zunächst CPC's und dann OB's aufgetragen wurden. Mittig ist der Nachweis von Runx2 bei einem Molekulargewicht von ca. 55-62 kDA und der Ladungskontrolle GAPDH bei ca. 40 kDA. In Abb7C erfolgt die grafische Darstellung der Proteinexpression von Runx2 im Vergleich zur Kontrolle, den CPC's.
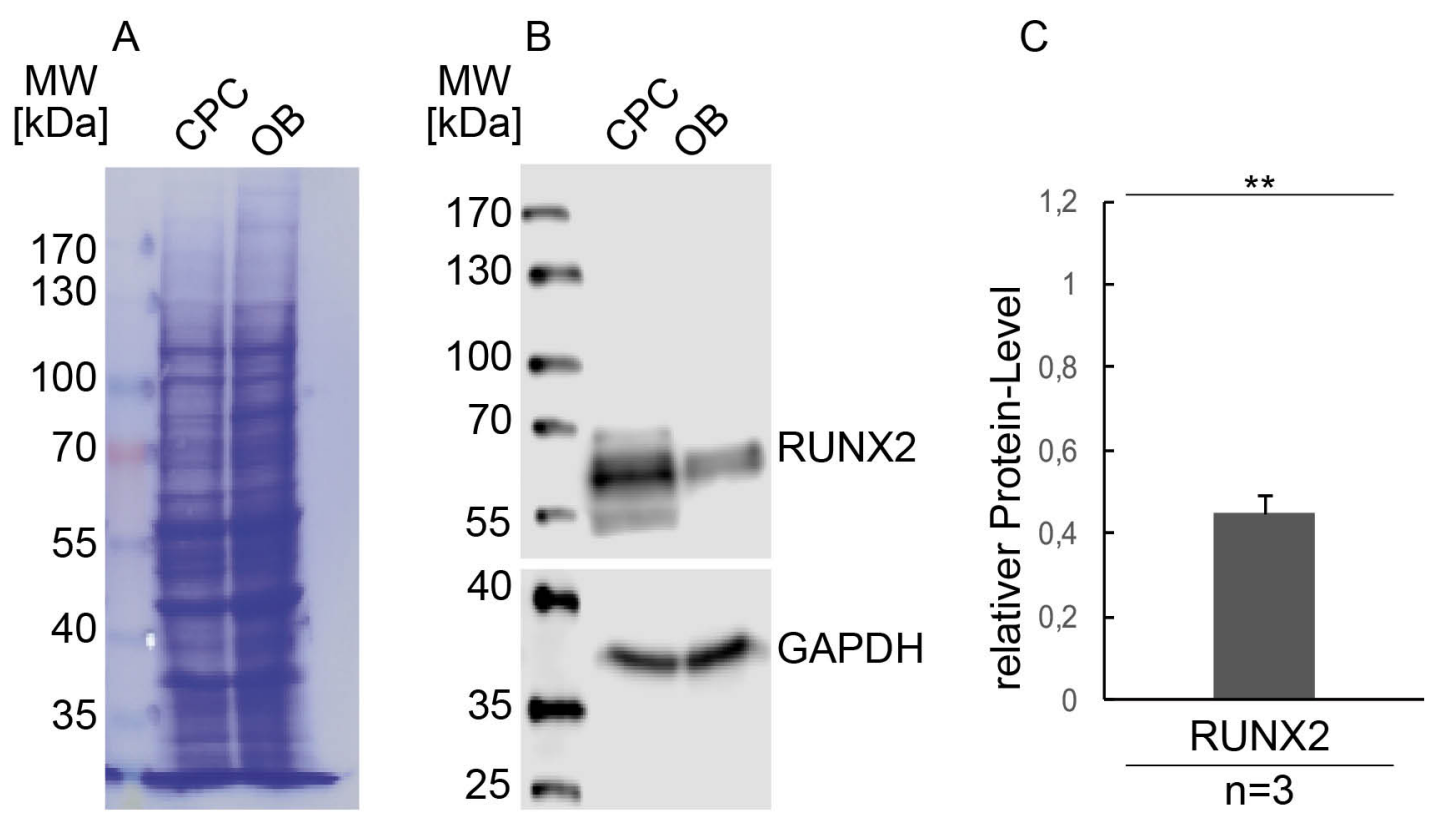

\section{Abbildung 8: Proteinnachweis von Runx2}

A: Coomassie-Färbung des Western Blots. B: Proteinnachweis von Runx2 bei dem Molekulargewicht von ca. 55-62 kDA und einer AK-Verdünnung von 1:1000 sowie von GAPDH bei einem Molekulargewicht von ca. $40 \mathrm{kDA}$ und einer AK-Verdünnung von 1:10000. GAPDH dient als Housekeeping-Gen zur Ladungskontrolle. C: Quantitative Auswertung der Proteinlevels von Runx2. Der Balken stellt den Mittelwert \pm Standardabweichung im Vergleich zur Kontrolle (festgesetzt als 1, CPC's) von drei getrennten Durchläufen $(n=3)$ dar. Dabei wurde die Standardabweichung wie folgt festgelegt: ${ }^{* *}<0,01$. Die Markierung 1 auf der y-Achse der grafischen Darstellung entspricht dem Kontrollwert. 


\subsection{Nachweis von SOX9 im Western Blot}

In Abbildung 9 erfolgt die bildliche sowie grafische Darstellung des Nachweises von Sox9 im Western Blot. Links ist ein Scan der entsprechenden Coomassie-Färbung der Proteinbanden abgebildet, wobei von links nach rechts zunächst CPC's, dann ZB's und dann OB's aufgetragen wurden. Mittig ist der Nachweis von Sox9 bei einem Molekulargewicht von ca. 56 kDA und der Ladungskontrolle GAPDH bei ca. 40 kDA. In Abb7C erfolgt die grafische Darstellung der Proteinexpression von Sox9 im Vergleich zur Kontrolle, den CPC's.

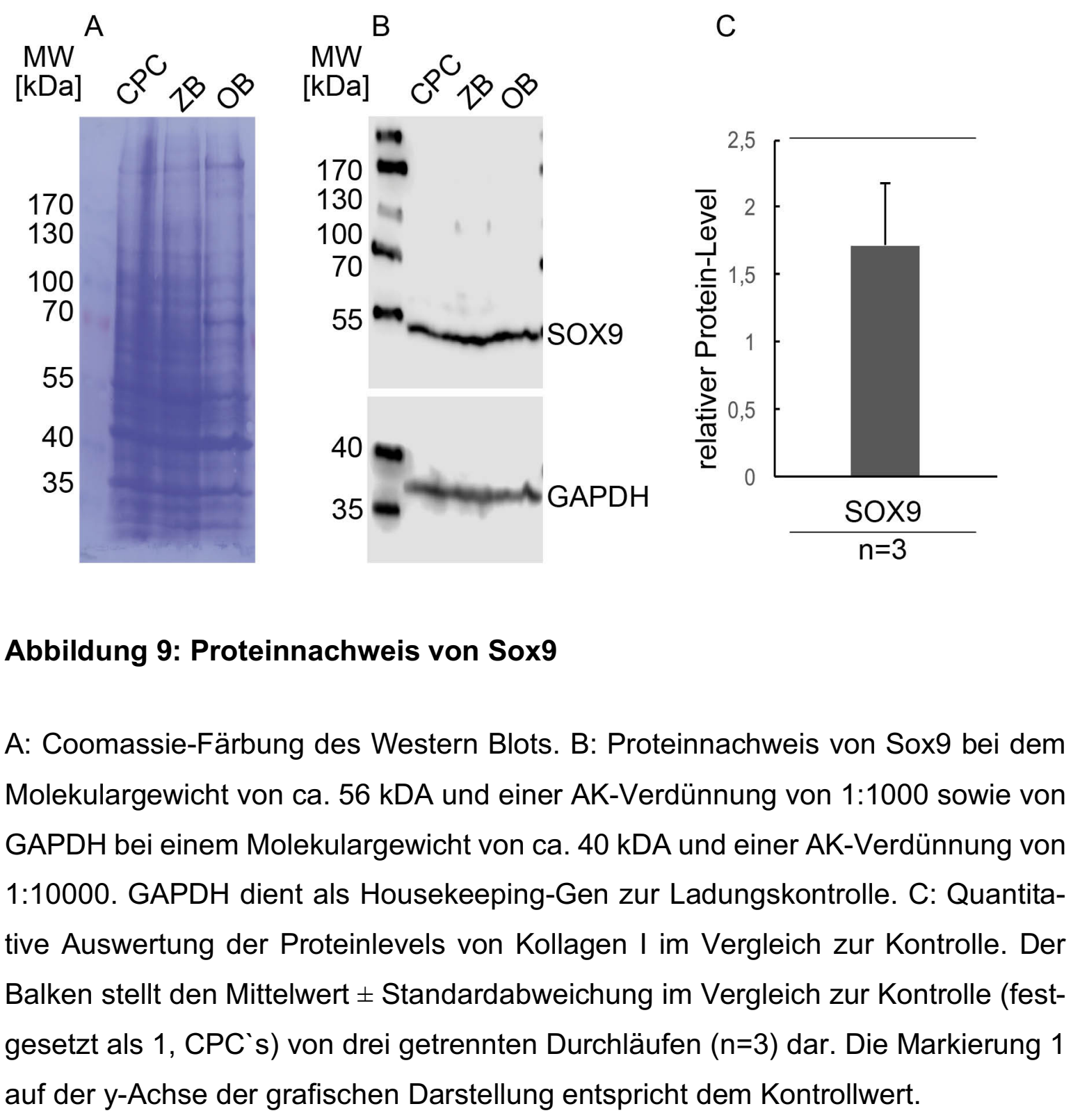




\subsection{Immunzytochemischer Nachweis verschiedener Matrixproteine}

Alle dargestellten Immunfluoreszenzfärbungen erfolgten unter den gleichen Bedingungen innerhalb eines Versuchsdurchlaufes.

In Abbildung 10 erfolgt der Nachweis von Runx2 in der Immunzytochemie. Zunächst ist eine Kontrolle dargestellt, zum Ausschluss von unspezifischen Bindungen des sekundären Antikörpers. In Abb9B ist die Färbung des Zellkerns der Osteoblasten mit dem Farbstoff DAPI sichtbar und Abb9C zeigt die erfolgreiche Färbung des Proteins Runx2, sowohl im Zytoplasma als auch im Zellkern zu erkennen. Im letzten Bild ist die Überlagerung der beiden Färbungen dargestellt.
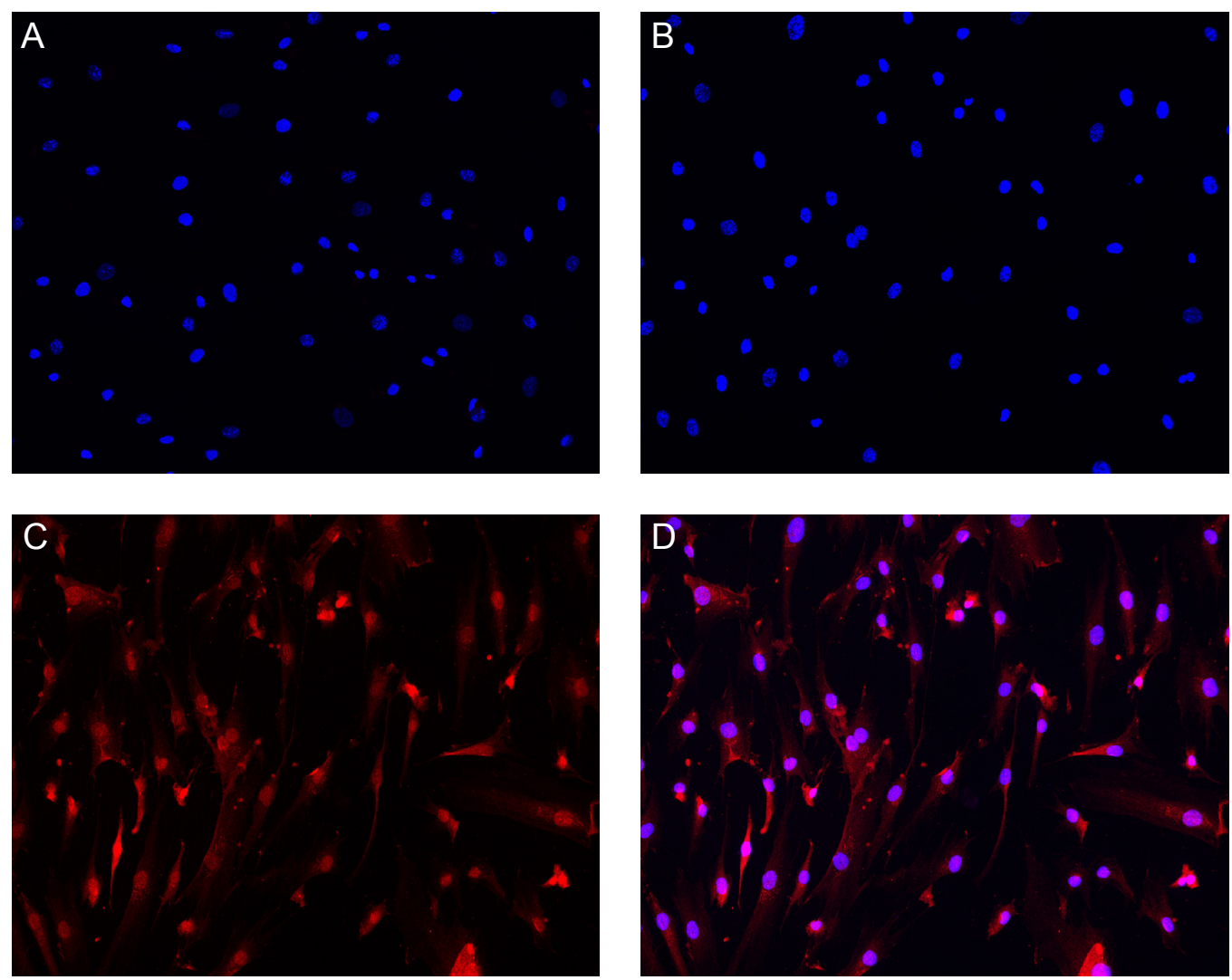

Abbildung 10: Immunzytochemischer Nachweis von Runx2 
A: Kontrollaufnahme. B: Färbung der Zellkerne mit dem Fluoreszenzfarbstoff DAPI (blau). C: Proteinnachweis von Runx2 im Zellkern und Zytoplasma (rot) mit Alexa Fluor 555. D: Overlay; 20-fach vergrößert.

In Abbildung 11 erfolgt der Nachweis von Sox9 in der Immunzytochemie. Zunächst ist eine Kontrolle dargestellt, zum Ausschluss von unspezifischen Bindungen des sekundären Antikörpers. In Abb9B ist die Färbung des Zellkerns der Osteoblasten mit dem Farbstoff DAPI sichtbar und Abbildung 9C zeigt die erfolgreiche Färbung des Proteins Sox9, sowohl im Zytoplasma als auch im Zellkern zu erkennen. Im letzten Bild ist die Überlagerung der beiden Färbungen dargestellt.
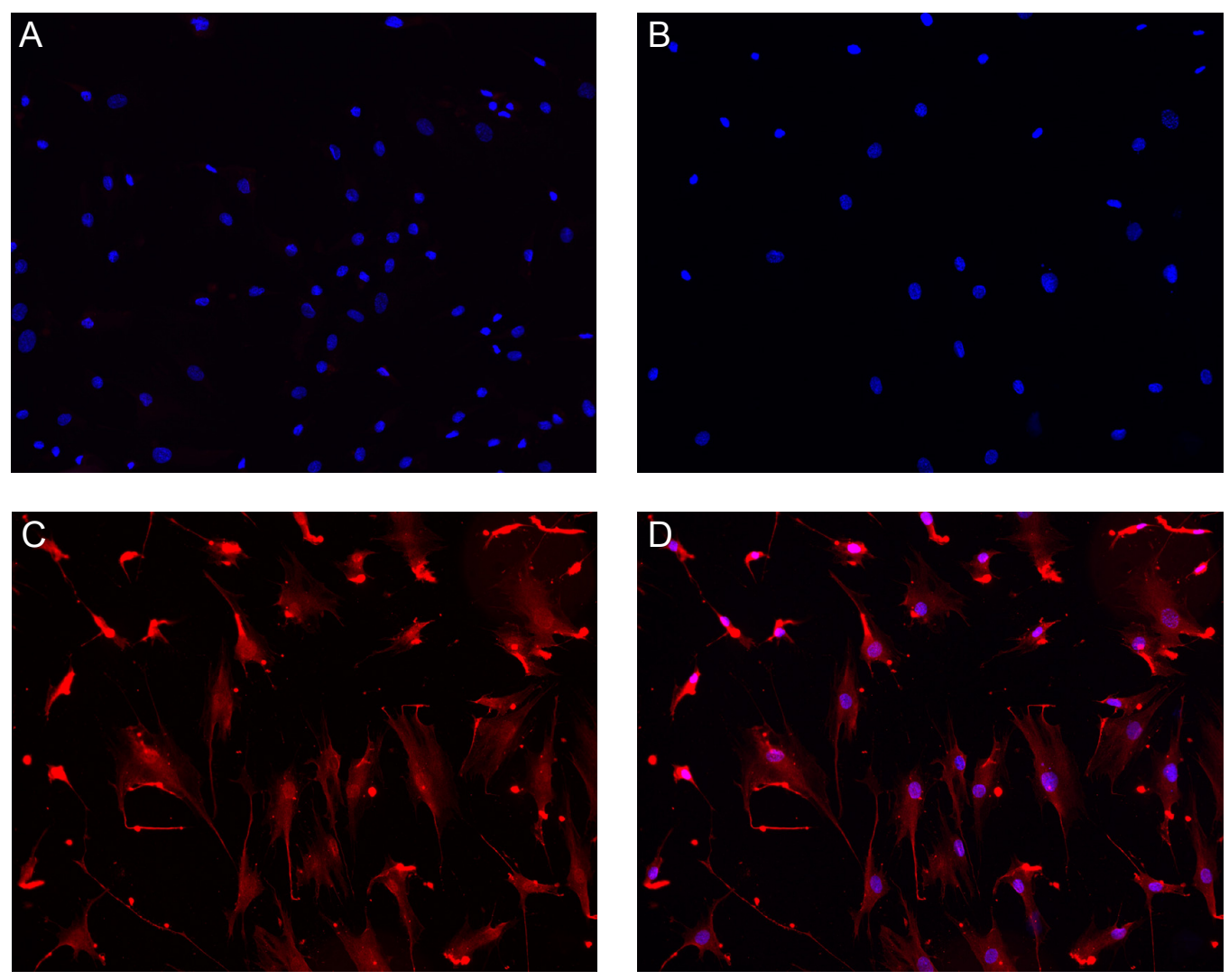

Abbildung 11: Immunzytochemischer Nachweis von Sox9 
A: Kontrollaufnahme. B: Färbung der Zellkerne mit dem Fluoreszenzfarbstoff DAPI (blau). C: Proteinnachweis von Sox9 im Zellkern und Zytoplasma (rot) mit Alexa Fluor 555. D: Overlay; 20-fach vergrößert. 
In Abbildung 12 erfolgt der Nachweis von verschiedenen Markerproteinen in der Immunzytochemie. Zunächst ist eine Kontrolle dargestellt, zum Ausschluss von unspezifischen Bindungen des sekundären Antikörpers. In den darauffolgenden Bildern ist die Färbung von Kollagen I, Dekorin, Osteopontin und CP-23 zu erkennen.
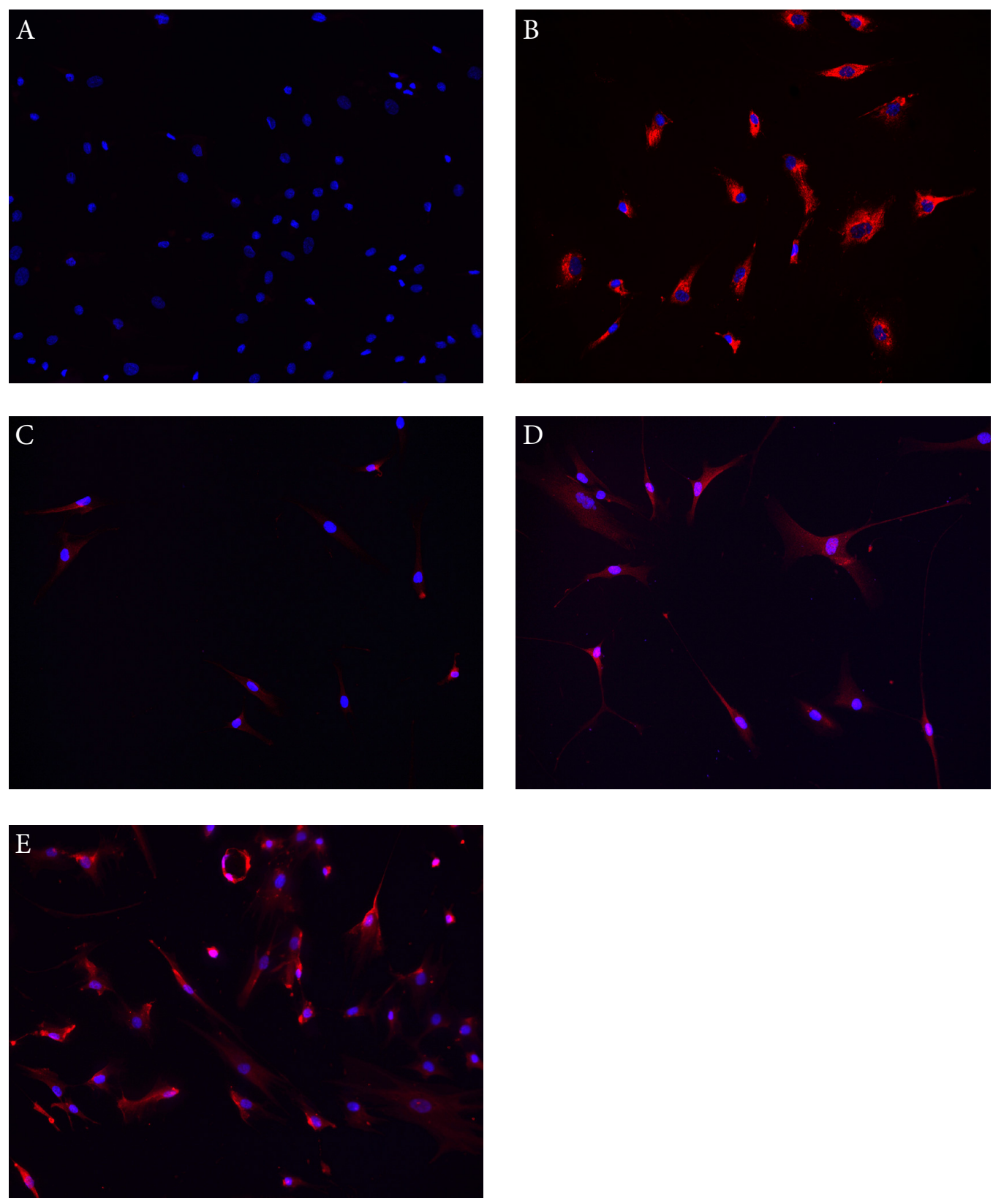

Abbildung 12: Immunzytochemischer Nachweis verschiedener Markerproteine 
A: Kontrollaufnahme. B: Nachweis von Kollagen I C: Nachweis von Dekorin. D: Nachweis von Osteopontin. E: Nachweis von CP-23, 20-fach vergrößert.

In Abbildung 13 erfolgt der Nachweis von Kollagen III in der Immunzytochemie. Zunächst ist eine Kontrolle dargestellt, zum Ausschluss von unspezifischen Bindungen des sekundären Antikörpers. In Abbildung 9B ist die Färbung des Proteins sowie des Zellkerns mit DAPI, bereits überlagert, dargestellt.
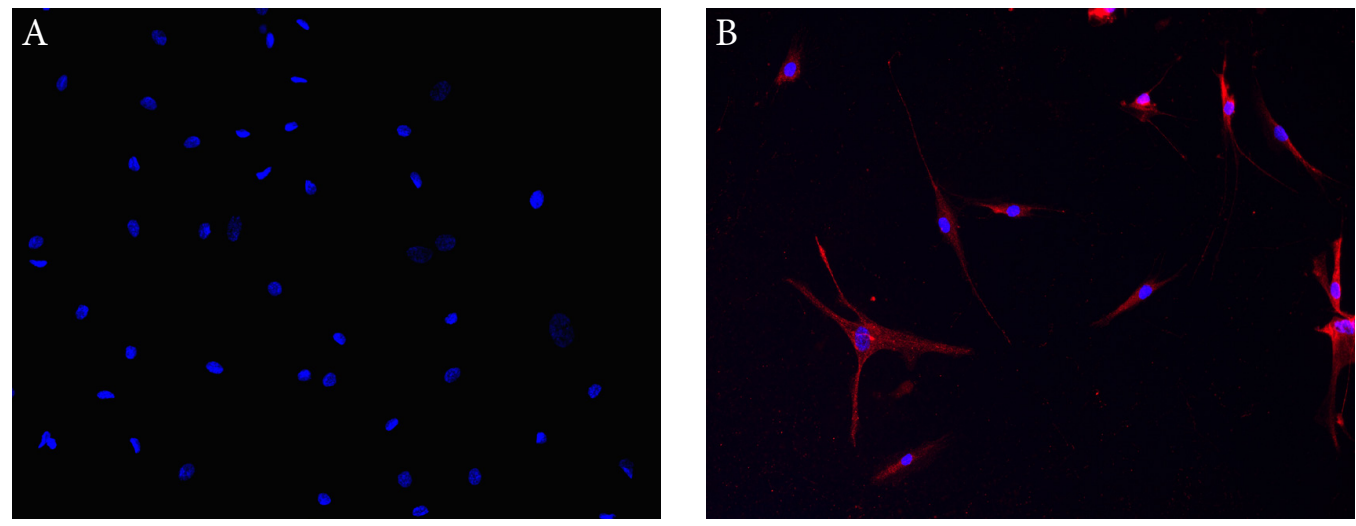

\section{Abbildung 13: Immunzytochemischer Nachweis von Kollagen III}

A: Kontrollaufnahme. B Nachweis von Kollagen III. 20-fach vergrößert. 
3.10 Nachweis verschiedener Marker in der Durchflusszytometrie

In Abbildung 14 erfolgt die grafische Darstellung der prozentualen Nachweise von Kollagen I, Osteonectin, Sox9 und Runx2 in der FACS-Analyse. Zu erkennen ist, dass Kollagen I als einziges Protein in über $50 \%$ der Osteoblasten nachgewiesen werden konnte, wobei Sox9 in ca. $42 \%$ der Zellen identifiziert wurde. Osteonectin konnte in $10 \%$ der Zellen und Runx2 in ca.15\% der Osteoblasten nachgewiesen werden. Aufgrund möglicher versuchsabhängiger Schwankungen konnte kein signifikanter Nachweis für Osteonectin erfolgen.

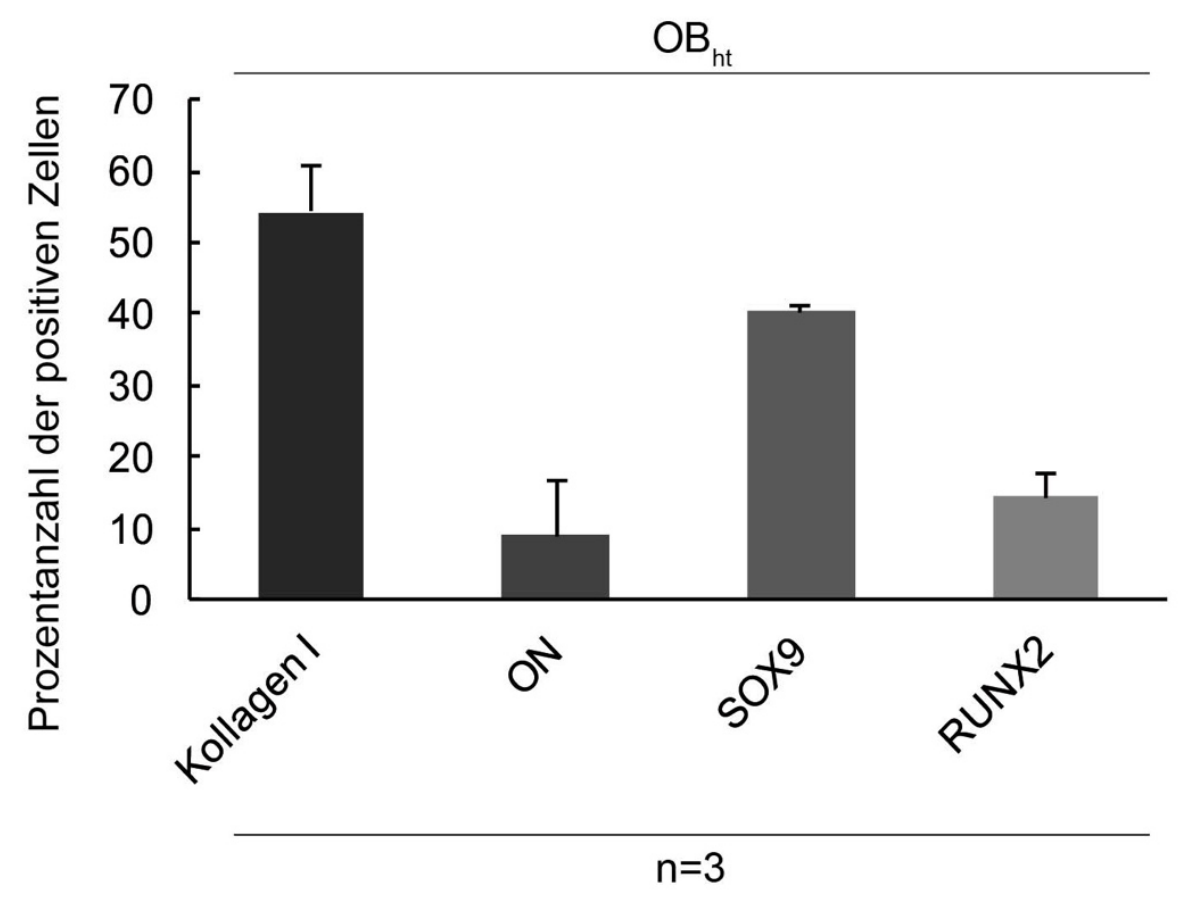

\section{Abbildung 14: Quantitative Auswertung der FACS-Analyse}

Dargestellt werden in Abbildung 14 die prozentualen Expressionsnachweise von Kollagen I, Osteonectin, Sox9 und Runx2. Dabei ergeben sich die Ergebnisse als Mittelwerte von drei getrennten Durchläufen $(n=3)$, wobei die Balken die Mittelwerte \pm Standardabweichung darstellen. 


\section{Diskussion}

Die für diese Arbeit gewonnenen osteoblastären Zellen stellen als knochenbildende Zellen eine der Hauptkomponenten in der Ausbildung eines funktionierenden Zahnhalteapparates dar. Ihre Osteoidproduktion und deren anschließende Mineralisierung spielen dabei die Hauptrolle, wobei sie darauffolgend ebenfalls an der Remodellierung des Knochens bei Wachstumsprozessen oder in Folge forcierter Zahnbewegungen beteiligt sind (Saffar et al. 1997).

Es gibt in der Literatur bereits einige Studien die sich mit den Charakteristika der Osteoblasten und deren Proteinexpression (Rodan et al. 1988) beschäftigen, jedoch keinerlei Erkenntnisse, welche aus dem humanen Alveolarknochen stammen. Aufgrund dessen wurde die Gewinnung und Charakterisierung der humanen Osteoblasten aus dem Alveolarknochen zum Thema dieser Arbeit gemacht, wobei unterschiedliche Marker auf verschiedenen Ebenen nachgewiesen wurden, um eine eindeutige Charakterisierung zuzulassen.

\subsection{Nachweis nicht-kollagener Knochenmatrixproteine}

Osteocalcin konnte als eines der nicht-kollagenen Matrixproteinen durch immunhistochemische Anfärbungen identifiziert werden. Während BSP und OPN in der frühen Phase der Kristallisationsbildung nachweisbar waren, wurden ON und Osteocalcin in der mineralisierten Matrix angefärbt (Roach 1994). Hauptsächlich von Osteoblasten produziert, ist Osteocalcin ein kleines, stark verbreitetes Knochenmatrixprotein, dessen Aufgabe noch nicht vollständig verstanden ist. Seine Beteiligung an der Knochenmineralisation und dessen Umbau ist allerdings sehr wahrscheinlich (Wolf 1996; Neve et al. 2013). Es ist nachgewiesen, dass Osteocalcin stark an Hydroxylapatit bindet, wobei hiermit dessen Wachstum und Vernetzung blockiert werden könnte und es zu einer verringerten Knochenbildung kommen kann (Boskey et al. 1985). Dies ist ein möglicher Grund für die gesteigerte Knochenmasse in Osteocalcin-knock-out-Mäusen sein (Ducy et al. 1996).

Die Osteocalcin-Expression in den untersuchten Osteoblasten wurde auf mRNAEbene in der qRT-PCR untersucht. Hier war sowohl ein Nachweis in immortalisierten, undifferenzierten Osteoblasten als auch in den osteogen differenzierten Osteoblasten möglich. Die mRNA-Expression in den undiffernzierten Osteoblasten lag 
geringfügig unter der Expression in den Kontrollzellen, den Zementoblasten aus dem humanen Zement. Ursprünglich nahm man an, dass Osteocalcin einen rein Osteoblasten-spezifischen Marker darstellt (Ducy et al. 1996; Ducy et al. 2000a), was hier eindeutig widerlegt wird. Außerdem lässt die nahezu identische Expression einen Rückschluss auf die Verwandtschaft dieser beiden Zelltypen zu.

Da Osteocalcin bereits als später osteogener Marker bekannt ist (Boskey et al. 1985), erfolgte die Auswertung der Protein-Expression nach einer osteogenen Differenzierung. Es war eine starke Zunahme des mRNA-Levels nach Auswertung der Ergebnisse zu erkennen, und zwar um mehr als das Dreifache. Dies bestätigt Ergebnisse aus anderen Studien, wobei diese erstmals auf den humanen Alveolarknochen zutreffen. Außerdem bestätigt der Nachweis die erfolgreiche osteogene Differenzierung.

Osteonectin ist ein Matrixprotein, dass an Hydroxylapatit, Kalzium und Kollagen I binden kann und an der Osteoidmineralisation beteiligt ist. Damit wurde $\mathrm{ON}$ als eines der wichtigsten nicht-kollagenen Matrixproteine identifiziert (Termine et al. 1981).

Auch bekannt als SPARC oder BM-40, ist Osteonectin häufig an Gewebestellen des aktiven Knochenumbaus zu finden. Es wird angenommen, dass dieses Protein die Interaktion zwischen Zellen und der EZM reguliert, indem es die Zellform mit seiner anti-adhäsiven Eigenschaft verändern kann. Außerdem passt es die Effizienz einiger Wachstumsfaktoren an und beeinflusst die Expression von Matrixmetalloproteinasen (MMP), wodurch die Wundheilung maßgeblich beeinflusst wird (Brekken und Sage 2001).

Inwiefern ON mit Zellen interagiert, ist nicht bekannt, da bisher kein SPARC-spezifischer Oberflächenrezeptor gefunden werden konnte. Es wird jedoch vermutet, dass es zu einem antagonistischen Verhalten bereits bekannter Wechselwirkungen von Rezeptoren und Liganden kommt (Bornstein und Sage 2002).

Außerdem wird angenommen, dass ON möglicherweise einen Einfluss auf die Malignität sowie das Fortschreiten von Tumoren hat und regulierend an diesen Prozessen beteiligt sein könnte. Charakteristisch für Osteonectin -/- Mäuse sind oft ein verfrühtes Auftreten des Grauen Stars (Katarakt), ein starker Knochenverlust sowie 
Fettleibigkeit und eine verringerte Dehnbarkeit der Haut durch verkleinerte Kollagenfasern (Brekken und Sage 2001; Framson und Sage 2004). In Studien konnte mit Hilfe des Maus-Modells gezeigt werden, dass Genmutationen von ON einen negativen Effekt auf die Mikroarchitektur des Knochens haben und es zur Ausbildung einer Osteopenie bei den Versuchstieren kam. Dies liegt vor allem an der verringerten Umbaurate des Knochens, bedingt durch eine verminderte Anzahl an Osteoblasten und Osteoklasten (Delany et al. 2000).

Aufgrund der Tatsache, dass die Knochensubstanz ständigen Remodellierungsprozessen unterliegt und dies auch auf den Alveolarknochen zutrifft, wäre ein deutlicher Expressionsnachweis von ON anzunehmen. Es erfolgte ein Nachweis von $10 \%$ des Proteins in der Gesamtmenge der Osteoblasten mittels der Durchflusszytometrie, wobei dieses Ergebnis starken Schwankungen unterlag und nicht signifikant ist. Obwohl der Versuch mehrmals unter den gleichen Bedingungen durchgeführt wurde, konnte Osteonectin nicht konstant in den humanen, undifferenzierten Osteoblasten aus dem Alveolarknochen nachgewiesen werden.

Die Funktion von Bone Sialoprotein, einem weiteren nicht-kollagenen Matrixprotein, ist bisher nicht vollständig bekannt, wobei eine Rolle in der Biomineralisation angenommen wird. Im Maus-Modell konnte das Protein den Zellen der aktiven Knochen, Dentin- und Zementbildung zugeordnet werden, wobei eine Expression erst in gereiften Osteoblasten nachzuweisen war (Chen et al. 1992).

BSP wird von einem Gen codiert, welches zur SIBLING-Familie (small integrin-binding ligand $N$-linked glycoproteins) gehört und deren spezifische Eigenschaften besitzt. Darunter fällt der Besitz einer RGD-Einheit, bestehend aus drei Aminosäuren, die dazu in der Lage ist, Integrin zu binden (Bellahcène et al. 2008). Einige SIGLING`s können außerdem verschiedene MMP's aktivieren und den Komplementfaktor $\mathrm{H}$ binden. Dies geschieht vor allem durch das sezernieren von BSP in Tumorzellen, woraufhin eine komplementaktivierte Zelllyse verhindert wird, korrelierend mit der Aggressivität des Tumors (Fedarko et al. 2000; Bellahcène et al. 2008). BSP -/- Mäuse zeigen eine dramatische Reduzierung an reifen Osteoblasten und verringerte Nachweise TRAP-positiver Zellen, den Osteoklasten. Junge BSP-/- Mäuse waren deutlich kleiner und leichter, wiesen eine dünnere Kortikalis, ebenso wie verkürzte Oberschenkelknochen auf, wohingegen ihr trabekuläres Knochenvolumen 
um ca. $25 \%$ anstieg. Die Größenunterschiede glichen sich mit fortschreitendem Wachstum aus, wobei eindeutig nachgewiesen ist, wie groß die Rolle der Knochenbildung von BSP ist (Malaval et al. 2008).

Der Proteinnachweis von BSP erfolgte in dieser Studie durch qRT-PCR, wobei die mRNA-Expression unter dem Level der Kontrolle lag, hier den Zementoblasten.

Osteopontin gehört ebenso wie BSP zur Gruppe der SIBLING`s, und besitzt die damit verbundenen Eigenschaften. Es ist außerdem eine Abhängigkeit dieser beiden Matrixproteine voneinander zu vermuten, da sich in BSP -/- Mäusen auch die Expression von OPN verringert (Bellahcène et al. 2008; Malaval et al. 2008). Dieses stark phosphorylierte Protein ist an Stellen der Mineralisation zu finden, wo es bei Knochenumwandlungsprozessen und der Kalzifizierung eine Rolle spielt. Es konnte außerdem ein Bezug auf die Wundheilung, Tumorbildung und immunologische Reaktionen festgestellt werden, wobei OPN -/- Mäuse keine eindeutige Zuordnung zu spezifischen Geweben zeigten (Sodek et al. 2000).

Vor allem in der Tumorforschung ist seit längerem bekannt, dass OPN in aggressiven Tumoren überexprimiert wird und mit dessen Malignität korreliert. Die OPNabhängige Aktivierung des Akt-Signalweges spielt hierbei eine entscheidende Rolle, durch den die Apoptose, der programmierte Zelltod, verhindert werden kann (Robertson und Chellaiah 2010).

OPN wird also nicht nur in Knochenzellen exprimiert, sondern ebenso in Immunzellen, Muskelzellen sowie Zellen in der Niere und in dem Gehirn, wodurch eine breite Spannweite seiner Funktionen anzunehmen ist. Ein Zusammenhang zur Adipositas, Nierenversagen und Typ 2 Diabetes ist ebenfalls festgestellt worden (De Fusco et al. 2017).

Aufgrund dieser Kenntnisse lag der Nachweis von Osteopontin in den untersuchten Osteoblasten nahe, da diese Zellen zur raschen Proliferation fähig sein müssen, um Umbauprozesse infolge äußerer Einwirkungen durchführen zu können. Es war erstmalig möglich Osteopontin in Knochenzellen aus dem humanen Alveolarknochen in vitro durch die Immunzytochemie nachzuweisen. 


\subsection{Nachweis von Kollagentyp I und III}

In vorangegangenen Studien konnte nachgewiesen werden, dass die von Osteoblasten sezernierte Knochenmatrix zum größten Teil aus einer Mischung unterschiedlicher Kollagenfasertypen besteht. Durch Untersuchungen an Zähnen von Hausschweinen wurde Kollagentyp I als Hauptkomponente nachgewiesen (Rao et al. 1979), ebenso strahlen Fasern vom Kollagentyp III als sogenannte Sharpey`sche Fasern, zusammen mit Typ I, von extern in den Alveolarknochen ein (Wang et al. 1980). Aufgrund dieser bereits gewonnenen Ergebnisse wurde erwartet, einen deutlichen Nachweis von Kollagen I zu erhalten und ein vergleichsweise geringeres Ergebnis für Kollagen III, wobei von Anfang an bedacht wurde, dass die vorangehenden Nachweise aus Tiermodellen stammen.

Innerhalb der Experimente konnten die Kollagentypen I und III auf mRNA-Ebene in der qRT-PCR nachgewiesen werden. Die Expression von Kollagen I ist weniger als ein Drittel so stark wie die Expression in den Kontrollzellen. An dieser Stelle wäre es interessant zu sehen, ob nach erfolgter Differenzierung eine Änderung dieses Expressionsverhaltens festzustellen ist oder ob die Nachweise konstant bleiben würden. Beide Kollagentypen konnten zum ersten Mal in der Immunzytochemie nachgewiesen werden. Ebenso war es möglich, Kollagen I auf Proteinebene im Western Blot nachzuweisen sowie in der Durchflusszytometrie. Im Western Blot lag die Standardabweichung unter 0,01, weshalb das Ergebnis als signifikant zu bewerten ist. In der Durchflusszytometrie wurde Kollagen I in über 50\% der osteoblastären Zellen nachgewiesen.

\subsection{Nachweis der Transkriptionsfaktoren RUNX2 und SOX9}

Runx2 ist ein bedeutender Transkriptionsfaktor für Zellen der osteoblastären Linie. In vergangenen Studien konnte festgestellt werden, dass die Expression von Runx2 spezifisch auf skelettbildende Zellen sowie Mesenchymalzellen zutrifft und in Verbindung mit der Sekretion bestimmter osteogener Marker, wie Osteocalcin, BSP, Kollagen I und OPN gebracht werden kann (Ducy et al. 1997; Lamour et al. 2007). Zugehörig zur Runx-Familie konnten drei Gene identifiziert werden. Runx1, Runx2 und Runx3, welche alle unterschiedliche Funktionen erfüllen, wobei jeder Faktor 
eine DNA-Bindungsdomäne enthält. Runx2 scheint als einziger Faktor mit der Knochenbildung zusammenzuhängen, wohingegen Runx1 die Hämatopoese reguliert und Runx3 das Wachstum von Epithelzellen im Magen mitbestimmt (Komori und Kishimoto 1998; Li et al. 2002, S. 3).

Als wichtiges Merkmal wurde nachgewiesen, dass Runx2 an OSE2 bindet. OSE2 findet sich in den Promotor-Genen von Osteocalcin, BSP, Osteopontin sowie Kollagen I und initiiert deren Expression (Ducy et al. 1997). Viele unterschiedliche Studien haben sich mit Runx2 und seinen Eigenschaften beschäftigt, weshalb mittlerweile bekannt ist, dass dieser Transkriptionsfaktor die Entwicklung von Mesenchymzellen zu Adipozyten und Chrondrozyten blockiert und zugunsten ihrer Entwicklung herunterreguliert werden muss. Es konnte sogar eine Differenzierung von frühen Odontoblasten zu Osteoblasten unter der Hochregulierung von Runx2 festgestellt werden (Komori 2008; Miyazaki et al. 2008). Bereits in Präosteoblasten ist eine Identifizierung von Runx2 möglich, besonders in der Phase unreifer Osteoblasten wurde der Faktor vermehrt erkannt, wohingegen seine Expression in reifen Osteblasten herunterreguliert wurde (Komori 2010). In einer neuen Studie wurde außerdem nachgewiesen, dass der Citrat-Carrier CIC-3 mit Hilfe des Runx2-Signalweges an der Differenzierung von Osteoblasten und der Regulation osteoblastärer Marker beteiligt ist (Wang et al. 2010).

Es ist in dieser Arbeit erstmals gelungen, Runx2 in der Durchflusszytometrie nachzuweisen, ebenso wie auf mRNA-Ebene in der qRT-PCR als auch auf Proteinebene im Western Blot. Die Expression der mRNA in humanen Osteoblasten liegt dabei unter der Expression der Kontrollzellen, den humanen Zementoblasten. Wobei der Proteinnachweis über dem Nachweis der Kontrollzellen im Western Blot lag, hier den CPC's. In der FACS-Analyse liegt der Nachweis bei ca. 15\%. Eine Erklärung für den niedrigen Nachweis von Runx2 auf mRNA-Ebene wäre, dass es sich um reifere Osteoblasten handelt, weshalb eine Herunterregulierung möglicherweise eine Rolle spielt. Demnach wäre auch nach weiterer osteogener Differenzierung kein erhöhter Nachweis zu erwarten.

Der Transkriptionsfaktor Sox9 wurde erstmalig 1990 identifiziert (Gubbay et al. 1990 ) und gehört zur Familie (SRY-related high mobility group) der SOX-Transkrip- 
tionsfaktoren. Alle Gruppenmitglieder besitzen eine aus 70-80 Aminosäuren bestehende DNA-bindende Domäne, die als high mobility group (HMG-Box) bezeichnet wird (Laudet et al. 1993). Seine Namensgebung resultiert aus der hohen Übereinstimmung dieser Domäne zu der HMG-Box der Transktiptionsfaktors SRY (Sex determing region of Y-Gen), lokalisiert auf dem Y-Chromosom (Wegner 1999; Bowles et al. 2000). An den Enden der DNA-bindenden Domäne befinden sich zwei Kernlokalisationssignale (NLS= nuclear localization signals), die den Transport von Sox9 in den Zellkern auslösen (Südbeck und Scherer 1997), sowie ein Exportsignal (NES = nuclear export signal), zuständig für den Transport von Sox9 vom Zellkern heraus ins Zytoplasma (Gasca et al. 2002).

Im Maus-Modell konnte Sox9 als ein entscheidender Transkriptionsfaktor für die Knorpelentwicklung identifiziert werden. Das Kollagen II codierende Gen, Col2a1, wird von Sox9 aktiviert und löst damit die Knorpelbildung aus. Es wurde nachgewiesen, dass die Expression von Sox9 und Col2a1 ähnlich stark ausfällt und eine Abhängigkeit voneinander besteht. Außer dem Nachweis in chondrogenen Vorläuferzellen und Chondrozyten, konnte Sox9 im Pankreas, der Niere, dem Herz sowie den männlichen Keimdrüsen und den Ohrenanlagen identifiziert werden ( $\mathrm{Ng}$ et al. 1997; Zhao et al. 1997). Mutationen des Sox9-Genes resultieren in der kampomelen Dysplasie, gekennzeichnet durch skelettale Missbildungen wie unterentwickelte Schulterblätter oder ausgerenkte Hüften (Wegner 1999). Es konnte ebenfalls nachgewiesen werden, dass Sox9 die Differenzierung hypertropher Chondrozyten zu Osteoblasten in der Maus inhibiert (Dy et al. 2012). Ein Zusammenhang zwischen der Expression von Sox9 und Runx2 konnte anhand von Forschungen mit multipotenten chondrogenen Progenitorzellen nachgewiesen werden. Infolge der Herunterregulation von Runx2 ließ sich eine erhöhte Expression von Sox9 feststellen (Koelling et al. 2009).

Erstmals konnte innerhalb dieser Arbeit der Transkriptionsfaktor Sox9 in humanen, undifferenzierten Osteoblasten nachgewiesen werden. In der Durchflusszytometrie und Immunzytochemie erfolgte der positive Nachweis von Sox9. Ebenso in der qRTPCR und im Western Blot. Die mRNA-Expression von Sox9 ist zweieinhalb Mal so groß wie die Expression in der Kontrolle, den humanen Zementoblasten, wobei ein hoher Expressionsunterschied zwischen Sox9 und Runx2 vorlag. Erklären lässt sich dies durch die bekannte Wechselwirkung der beiden Transkriptionsfaktoren, welche 
vermutlich auch in den Osteoblasten aktiv ist. Der Nachweis von Sox9 im Western Blot liegt über dem Kontrollnachweis, wobei er statistisch nicht signifikant ist.

\subsection{Nachweis von VEGF}

Der Vascular endothelial growth factor spielt eine entscheidende Rolle beim Knochenwachstum sowie dessen Remodellierung und Reparatur. Bereits das Fehlen einer einzigen Allele des Vegf-Gens, führte zur veränderten Entwicklung der Blutgefäße und Schäden des kardiovaskulären Systems bei Mäusen, woran die Notwendigkeit von Vegf für die Vaskulogenese deutlich wird (Carmeliet et al. 1996; Ferrara 1999; Gerber et al. 1999).

Vegf ist beteiligt an der Proliferation von Epithelzellen, Zellmigration und dazu in der Lage die Apoptose zu inhibieren. Sowohl Vaskulogenese als auch Angiogenese werden von diesem Faktor angeregt, wobei Vegf an zwei tyrosin-kinase Rezeptoren in Epithelzellen bindet, VEGFR-1 und -2. In Bezug auf die Tumorgenese kann die Blockierung der Vegf-Expression zum Stoppen des Tumorwachstums führen, welches bis dahin von seiner Expression profitiert (Ferrara 1999; Neufeld et al. 1999). In unterschiedlichen Studien konnte außerdem nachgewiesen werden, dass VegfA die Einwanderung von humanen mesenchymalen Vorläuferzellen und humanen Osteoblasten stimuliert (Mayr-Wohlfart et al. 2002; Fiedler et al. 2005). Aufgrund dieser Tatsache, wurde die Vegf-Expression in den untersuchten Osteoblasten erwartet.

In der qRT-PCR erfolgte ein Nachweis der mRNA von Vegf, wobei die Expression deutlich unter dem Kontrollnachweis lag. Die niedrige Expression lässt sich damit erklären, dass Osteoblasten in vitro nicht an realer Knochenbildung und -regeneration beteiligt sind und daher keine Notwendigkeit besteht Vegf erhöht zu produzieren.

\subsection{Nachweis von CP-23}

Das Protein CP-23 wurde bisher als Parodontal- bzw Zement-spezifisch klassifiziert, aufgrund hoher mRNA-Expressionen in der qRT-PCR (Alvarez-Pérez et al. 2006). Es konnte außerdem eine starke Reduzierung der CEMP1-Expression während der Differenzierung von PDL-Zellen zu Osteoblasten festgestellt werden, wohingegen 
eine Überexpression zugunsten der Entwicklung von Zementoblasten ausfiel (Komaki et al. 2012). In einer weiteren Studie wurde nachgewiesen, dass eine Infektion von humanen Gingivafibroblasten mit CP-23 zu erhöhten Gen-Expressionen von ALP, BSP, Osteocalcin und OPN sowie des Transkriptionsfaktors Runx2 und dem CAP (cementum attachment protein) führte (Carmona-Rodríguez et al. 2007), die wiederum nicht nur in der Zementogenese eine Rolle spielen, sondern auch in der Knochenbildung.

Als Schlüsselregulator der Zementogenese, ist CP-23 regulierend an der Zelldifferenzierung sowie -anhaftung von Zementoblasten, Zementbildung und der Organisation von Hydroxylapatitkristallen beteiligt. Abgesehen von seinem Vorkommen in zementbildenden Zellen konnte CP-23 allerdings auch in verschiedenen Tumorzellen von Brust-, Prostata- und Gebärmutterkrebs nachgewiesen werden. Wobei CP23 hier scheinbar unterschiedlichste Funktionen erfült, vom Zellwachstum und deren Differenzierung, bis hin zum Zelltod (Bermúdez et al. 2015).

In dieser Studie konnte CP-23 erstmals in humanen Osteoblasten aus dem Alveolarknochen nachgewiesen werden, entgegen der Annahme, dass CP-23 ein charakteristisches Merkmal für die oben genannten Zellgruppen darstellt. Ein Nachweis dieses Proteins in Osteoblasten lässt sich eventuell durch eine Studie erklären, in der man feststellen konnte, dass nach erfolgter osteogener Differenzierung von periapikalen follikulären Stammzellen (PAFSC's) und PDL-Stammzellen (PDLSC's) ein Anstieg der CP-23-Expression zu erkennen ist (Choi et al. 2014).

Der Nachweis erfolgte in der Immunzytochemie sowie qRT-PCR, wobei hier die mRNA-Expression über der Expression in der Kontrolle lag, den humanen Zementoblasten. Die Expression überstieg außerdem den Nachweis der Kollagentypen I und III, Runx2 und wichtiger Matrixproteine, wie beispielsweise Osteocalcin. Aufgrund dieser Nachweise wurde CP-23 nach osteogener Differenzierung erneut untersucht und festgestellt, dass die mRNA-Expression nach zweiwöchiger Differnzierung nur noch halb so groß war. Dies spricht dafür, dass CP-23 in gereiften Osteoblasten eine untergeordnete Rolle spielt, jedoch nicht als spezifischer Zementoblastenmarker geeignet ist. 


\subsection{Nachweis der Proteoglykane Dekorin und Versikan}

Proteoglykane besitzen mindestens eine kovalent gebundene Glykosaminoglykankette (GAG), aus sich wiederholenden Dissachariden, pro Protein und werden immunhistochemisch in vier Typen eingeteilt. Heparin/Heparansulfat, Chondroitin/Dermatansulfat, Keratansulfat und Hyaluronsäure. Die Gesamtheit der PG's bilden eine gallertige Grundsubstanz aus, in der Kollagen- sowie Elastinfasern eingebettet sind (Hay 1991; lozzo 1998).

Das PG Versikan gehört zur Gruppe leucin- und hyaluronbindender PG`s. An seinem N-terminalen Ende wird Hyaluron gebunden, die GAG's an seiner zentralen Domäne und Lectine an seinem C-terminalen Ende. Versikan wird in embryonalem Gewebe exprimiert und beeinflusst dort die Verbindung von embryonalen Fibroblasten mit Kollagen, Laminin und Fibronektin. Außerdem konnte es in Schichten von Arterienwänden nachgewiesen werden und in Haarfollikeln. In einer Anzahl unterschiedlicher Tumore, vor allem in den hyaluronreichen Regionen wurde dieses PG ebenfalls identifiziert (lozzo 1998). Aufgrund der hyaluronbindenen Eigenschaften von Versikan wurde dessen Expression in Knochenzellen ebenfalls erwartet. Erstmals konnte Versikan in humanen Osteoblasten nachgewiesen werden. Dies erfolgte mittels qRT-PCR, wobei die mRNA-Expression über der Expression in der Kontrolle lag, den Zementoblasten. Lediglich die Expression von Sox9 überstieg diesen Nachweis in der qRT-PCR, ansonsten waren die niedrigeren Expressionen der verschiedenen Kollagene und anderer bekannter nicht-kollagener Matrixproteine interessant.

Dekorin gehört zur Klasse I der SLRP`s, welche charakterisiert sind durch eine zentrale leucinreiche Domäne mit kleinen Cysteinansammlungen. Es können vier unterschiedliche Domänen in diesem PG erkannt werden. Domäne I enthält ein Signalund Propeptid, Domäne II enthält die GAG's sowie vier Cysteinrückstände, Domäne III ist leucinreich und Domäne IV enthält eine Schleife aus Cysteinrückständen (Iozzo 1998). Nachweise von Dekorin erfolgten in der Kollagenmatrix, im Knochen und in Zähnen (lozzo und Murdoch 1996). 
Dekorin spielt eine entscheidende Rolle in der Kollagensynthese, wobei seine Expression wichtig für das Wachstum der Fibrillen und deren Zusammenlagerung zu sein scheint. In verschiedenen Studien wurde nachgewiesen, dass Dekorin an Kollagenfasern vom Typ I und II bindet (Hedbom und Heinegård 1989) und es die Fibrillenformation verzögern kann (Vogel et al. 1984). Es konnte sogar gezeigt werden, dass es zusätzlich zur Verzögerung der Formation, den Fibrillendurchmesser verkleinern kann (Vogel und Trotter 1987).

Dekorin wurde im Laufe dieser Studie in der Immunzytochemie sowie qRT-PCR nachgewiesen, wobei die mRNA-Expression lediglich einem Zehntel der Expression in der Kontrolle entsprach. Da Dekorin wichtige Funktionen innerhalb der Knochenbildung einnimmt, spricht dies entgegen der bisherigen Annahmen. Da es sich jedoch um ein in vitro Experiment handelt, ist es möglich, dass eine veränderte Expression in vivo stattfindet.

\subsection{Nachweis von alkalischer Phosphatase, RANKL und Sclerostin}

Das membrangebundene Enzym alkalische Phosphatase wird in der Plasmamembran von Osteoblasten sowie Matrixvesikeln gefunden und an Stellen der aktiven Kristallbildung aus Hydroxylapatit nachgewiesen. Die alkalische Phosphatase scheint an der funktionellen und strukturellen Ausbildung der Knochen beteiligt zu sein, wobei Mutationen auf dem ALP-Gen zum Krankheitsbild der Hypophosphatasie führen können, was sich in einer gestörten Knochenmineralisierung äußert und von instabilen Knochen mit Frakturgefahr bis hin zu Stillgeburten eine lebensbedrohliche Gefahr darstellt. (Van Hoof und De Broe 1994). Momentan gilt der Nachweis von ALP als eindeutiger Indikator für die osteogene Differenzierung und Merkmal von Präosteoblasten und Osteoblasten (Pinero et al. 1995; Heinemann et al. 2000) In einer Studie konnten erhöhte Knochenserumwerte für ALP unter erhöhtem Knochenmetabolismus und erniedrigte Werte bei Patienten unter Bisphosphonattherapie nachgewiesen werden (Broyles et al. 1998).

Im Rahmen dieser Studie war es möglich ALP in der qRT-PCR nachzuweisen, wobei eine statistische Auswertung mittels Pfaffl nicht möglich war, da es keine Expression in den Kontrollzellen gab. Nach erfolgter Differenzierung war auch der 
Nachweis in den humanen Osteoblasten aus dem Alveolarknochen nicht mehr möglich.

RANKL ist an der Differenzierung der knochenabbauenden Osteoklasten maßgeblich beteiligt. Deren Entstehung erfolgt ausgehend von hämatopoetischen Stammzellen, die sich zu myeoloiden Progenitorzellen entwickeln. Dieser Vorläufer kann sich entweder osteoklastisch weiterentwickeln oder die Linie der Monozyten/Makrophagen ausbilden. Einkernige Präosteoklasten verschmelzen zu multinukleären TRAP-positiven Osteoklasten, welche anschließend aktiviert werden. Fördernd auf diesen Prozess wirkt RANKL, welcher von Osteoblasten produziert wird und an RANK bindet. Entgegen diesem Prozess wirkt Osteoprotegerin (Aubin und Bonnelye 2000). Runx2/Cbfa1 scheint RANKL zu fördern, ebenso wie Vitamin $D_{3}$, PGE2, IL-11 und das Parathormon (Aubin und Bonnelye 2000; Komori 2002).

Aufgrund dieser Kenntnisse wurde angenommen, RANKL in den humanen Osteoblasten aus dem Alveolarknochen nachweisen zu können. Sowohl in den undifferenzierten als auch in den differenzierten Osteoblasten, war jedoch keinerlei mRNANachweis in der qRT-PCR möglich.

Sclerostin wird von Osteozyten produziert, die in die osteoide Matrix eingebettet sind und dort in Knochenlakunen verweilen. In frisch eingebetteten Osteozyten konnte das Protein nicht nachgewiesen werden, wohingegen ausgereifte Osteozyten reich an Sclerostin sind und auch entlang ihrer dendritschen Ausläufer in Knochenkanälchen Nachweise möglich waren. Die Funktion dieses Proteins scheint in der Limitierung des Wnt-Signalweges zu liegen, womit die weitere Knochenproduktion gehemmt wird (Poole et al. 2005).

Eine erhöhte Knochendicke konnte bei Individuen mit reduzierter Sclerostinproduktion festgestellt werden, was in Extremfällen in dem autosomal vererbten Krankheitsbild der Sklerosteose manifestiert ist (Brunkow et al. 2001; Hamersma et al. 2003).

Die Annahme, dass Sclerostin bisher strikt mit Osteozyten in Verbindung gebracht wurde, konnte in dieser Studie bestätigt werden. Es war kein Nachweis sowohl vor 
als auch nach erfolgter osteogener Differenzierung in den humanen Osteoblasten aus dem Alveolarknochen möglich.

\subsection{Klinische Relevanz der Studie}

Die Notwendigkeit für Forschungen an knochenbildenden- sowie abbauenden Zellen wurde bereits früh erkannt, besonders aufgrund dessen, dass diese Knochenzellen oder deren sezernierte Proteine an vielen unterschiedlichen, teilweise schwerwiegenden Krankheitsbildern beteiligt sind. Darunter ist im zahnmedizinischen Bereich die Parodontitis zu nennen, die durch voranschreitenden Knochenabbau der beiden Kiefer zum Zahnverlust führen kann (Pihlstrom et al. 2005), aber auch andere Krankheitsbilder wie die Osteoporose (Kribbs et al. 1989; Kribbs 1990) und den Diabetes beeinflusst (Pihlstrom und Buse 2014; Teeuw et al. 2017). Des Weiteren ist für Patienten mit dem Wunsch nach einer Implantattherapie ein vollständiges Verstehen der Parodontitis notwendig, um mögliche Risikofaktoren und damit auftretende Kosten, ebenso wie gesundheitliche Probleme weitestgehend zu minimieren. Es konnte in verschiedenen Studien festgestellt werden, dass die Langzeiterfolge von Implantaten durch eine Parodontitis signifikant minimiert werden (Gatti et al. 2008).

Im Sinne der Geweberegeneration gibt es etliche Studien, die sich mit dem forcierten Knochenaufbau des Alveolar- und Kieferknochens beschäftigen, um Patienten eine Basis für weiterführende Rekonstruktionsmaßnahmen zu schaffen oder sogar den Verschluss von Kieferspalten anzuregen. Hierbei wird mit unterschiedlichen Materialien gearbeitet, wie beispielsweise Kollagenmembranen, anorganischem tierischen Mineral als auch Knochen aus demselben Individuum (Cordaro et al. 2002; Urban et al. 2013; Aly und Hammouda 2016). Wobei bis zum jetzigen Zeitpunkt nicht alle diese Therapien erfolgreich verlaufen (Draenert et al. 2016) und es bis heute schwer ist, einen vorangeschrittenen Knochenabbau aufzuhalten und zu versorgen. Neuere Therapieansätzen beschäftigen sich mit der Differenzierung von multipotenten mesenchymalen Stammzellen, die im dentalen Geweben identifiziert werden konnten. Die Eigenschaft dieser Zellen, sich in Osteoblasten und viele weitere Zelltypen zu differenzieren, soll sich in der Regeneration von dentalem Gewebe und Knochengewebe zu Nutze gemacht werden. Aufgrund dieser Entwicklungen 
und der Tatsache, dass der Alveolarknochen auch nach seiner vollständigen Entwicklung und ohne parodontale Erkrankung lebenslang einem Umwandlungsprozess unterliegt (Saffar et al. 1997), erfolgte die in dieser Arbeit durchgeführte Charakterisierung der osteoblastären Zellen aus dem Alveolarknochen. 


\section{Zusammenfassung}

Osteoblasten stellen eine für den Knochenaufbau und -umbau wichtige Zellgruppe dar, welche zusammen mit den Osteoklasten und Osteozyten entscheidend am Knochenmetabolismus beteiligt sind. Ihre Hauptaufgabe, die Sezernierung unterschiedlicher Knochenproteine und der unmineralisierten Knochenmatrix, spielt eine entscheidende Rolle bei der Ausbildung eines funktionierenden Skeletts.

In vorangegangenen Forschungen wurden osteoblastäre Zellen bereits auf unterschiedliche Proteine und Eigenschaften untersucht, diese Arbeiten erfolgten jedoch meist an tierischen Modellen und bisher nie an Zellen aus dem humanen Alveolarknochen. Diese Tatsache gab Anlass, die Gewinnung und Charakterisierung der Osteoblasten aus dem Alveolarknochen zum Thema dieser Studie zu machen und dabei einige der bereits andernorts erforschten Markerproteine zur Charakterisierung zu verwenden. Aufgrund dessen, dass in der Literatur einige Diskussionen und Unschlüssigkeiten bezüglich der Verwandtschaft dieser Zellgruppe mit Zementoblasten und Osteozyten herrschen, haben wir außerdem die Proteine CP-23 sowie Sclerostin hinzugezogen, die als Zement - bzw. Osteozyten-spezifisch gelten. Außerdem wurde der Transkriptionsfaktor Sox9 - aufgrund seiner nachgewiesenen Koabhängigkeit von Runx2 - zu den Untersuchungen hinzugenommen.

Zur ausführlichen Charakterisierung wurden vier unterschiedliche Methoden verwendet: die quantitative real-time PCR, der Western Blot, die Immunzytochemie und die Durchflusszytometrie. In den Ergebnissen der Arbeit ließen sich einige überraschende Nachweise feststellen. Vor allem die geringen Expressionen von Kollagen I, Runx2 und Dekorin wurden nicht erwartet. Wohingegen die Expressionen von Sox9 und CP-23 über der Expression einiger bekannter Knochenmatrixproteine lag. CP-23 scheint in seiner bisherigen Funktion als Zement-spezifischer Marker unzureichend erforscht zu sein, seine Expression war in den Osteoblasten höher als in den Kontrollzellen, den Zementoblasten. Der Osteozyten-spezifische Marker Sclerostin konnte wiederrum nicht in Osteoblasten nachgewiesen werden, was dessen bisherige Stellung verstärkt.

Ein weiterer Ansatz dieser Arbeit war die Überprüfung einiger Proteine nach erfolgter osteogener Differenzierung der Zellen, wobei sich daraufhin lediglich für CP-23 
und Osteocalcin Expressionen nachweisen ließen. Die erhöhte Osteocalcin-Expression und die erniedrigte Expression von CP-23 nach der Differenzierung entspricht der Annahme, dass es sich bei Osteocalcin um einen späten Marker handelt und CP-23 womöglich nur in frühen Phasen der osteoblastären Differenzierung vorkommt. Außerdem ist davon auszugehen, dass die durchgeführte osteogene Differenzierung gelungen ist.

Die vorliegende Arbeit zeigt, dass einige bekannte Knochenmatrixproteine im humanen Alveolarknochen nachzuweisen sind, wobei ebenso der Nachweis einiger knochenunspezifischer Proteine möglich ist. 


\section{Literaturverzeichnis}

Abramowitz J, Suki WN (1996): Ca-ATPase and bone cell mineralization. Miner Electrolyte Metab 22, 336-344

Al-Fakhri N, Hofbauer LC, Preissner KT, Franke FE, Schoppet M (2005): Expression of bone-regulating factors osteoprotegerin (OPG) and receptor activator of NF-kappaB ligand (RANKL) in heterotopic vascular ossification. Thromb Haemost $\underline{94}$, 1335-1337

Alvarez-Pérez MA, Narayanan S, Zeichner-David M, Rodríguez Carmona B, Arzate $H$ (2006): Molecular cloning, expression and immunolocalization of a novel human cementum-derived protein (CP-23). Bone $\underline{38}, 409-419$

Aly LAA, Hammouda N (2016): Secondary closure of alveolar cleft with resorbable collagen membrane and a combination of intraoral autogenous bone graft and deproteinized anorganic bovine bone. Ann Maxillofac Surg $\underline{6}$, 165-171

Anderson HC (1984): Mineralization by matrix vesicles. Scan Electron Microsc 953964

Ashton BA, Allen TD, Howlett CR, Eaglesom CC, Hattori A, Owen M (1980): Formation of bone and cartilage by marrow stromal cells in diffusion chambers in vivo. Clin Orthop 294-307

Aubin JE, Bonnelye E (2000): Osteoprotegerin and its ligand: A new paradigm for regulation of osteoclastogenesis and bone resorption. Medscape Womens Health $\underline{5}, 5$

Bartold PM, Narayanan AS (2006): Molecular and cell biology of healthy and diseased periodontal tissues. Periodontol $2000 \underline{40}$, 29-49 
Bartold PM, Walsh LJ, Narayanan AS (2000): Molecular and cell biology of the gingiva. Periodontol $2000 \underline{24}, 28-55$

Baylink DJ, Finkelman RD, Mohan S (1993): Growth factors to stimulate bone formation. J Bone Miner Res Off J Am Soc Bone Miner Res 8 Suppl 2, S565-572

Beertsen W, McCulloch CA, Sodek J (1997): The periodontal ligament: a unique, multifunctional connective tissue. Periodontol 2000 13, 20-40

Bellahcène A, Castronovo V, Ogbureke KUE, Fisher LW, Fedarko NS (2008): Small integrin-binding ligand $\mathrm{N}$-linked glycoproteins (SIBLINGs): multifunctional proteins in cancer. Nat Rev Cancer $\underline{8}, 212-226$

Bergström J (1984): The topography of papillary gingiva in health and early gingivitis. J Clin Periodontol $\underline{11}$, 423-431

Bermúdez M, Imaz-Rosshandler I, Rangel-Escareño C, Zeichner-David M, Arzate H, Mercado-Celis GE (2015): CEMP1 Induces Transformation in Human Gingival Fibroblasts. PloS One $\underline{10}$, e0127286

Bianco P, Fisher LW, Young MF, Termine JD, Robey PG (1990): Expression and localization of the two small proteoglycans biglycan and decorin in developing human skeletal and non-skeletal tissues. J Histochem Cytochem Off J Histochem Soc $\underline{38}, 1549-1563$

Bidanset DJ, Guidry C, Rosenberg LC, Choi HU, Timpl R, Hook M (1992): Binding of the proteoglycan decorin to collagen type VI. J Biol Chem $\underline{267}, 5250-5256$

Birn H (1966): The vascular supply of the periodontal membrane. An investigation of the number and size of perforations in the alveolar wall. J Periodontal Res $1,51-$ 68 
Bornstein P, Sage EH (2002): Matricellular proteins: extracellular modulators of cell function. Curr Opin Cell Biol 14, 608-616

Boskey AL, Wians FH, Hauschka PV (1985): The effect of osteocalcin on in vitro lipid-induced hydroxyapatite formation and seeded hydroxyapatite growth. Calcif Tissue Int $\underline{37}$, 57-62

Bosshardt DD (2005): Are cementoblasts a subpopulation of osteoblasts or a unique phenotype? J Dent Res 84, 390-406

Bosshardt DD, Selvig KA (1997): Dental cementum: the dynamic tissue covering of the root. Periodontol $2000 \underline{13}, 41-75$

Bowles J, Schepers G, Koopman P (2000): Phylogeny of the SOX family of developmental transcription factors based on sequence and structural indicators. Dev Biol $\underline{227}, 239-255$

Brekken RA, Sage EH (2001): SPARC, a matricellular protein: at the crossroads of cell-matrix communication. Matrix Biol $\underline{19}$, 816-827

Bronckers AL, Farach-Carson MC, Van Waveren E, Butler WT (1994): Immunolocalization of osteopontin, osteocalcin, and dentin sialoprotein during dental root formation and early cementogenesis in the rat. J Bone Miner Res $\underline{9}$, 833-841

Broyles DL, Nielsen RG, Bussett EM, Lu WD, Mizrahi IA, Nunnelly PA, Ngo TA, Noell J, Christenson RH, Kress BC (1998): Analytical and clinical performance characteristics of Tandem-MP Ostase, a new immunoassay for serum bone alkaline phosphatase. Clin Chem 44, 2139-2147

Brunkow ME, Gardner JC, Van Ness J, Paeper BW, Kovacevich BR, Proll S, Skonier JE, Zhao L, Sabo PJ, Fu Y, et al. (2001): Bone dysplasia sclerosteosis results from 
loss of the SOST gene product, a novel cystine knot-containing protein. Am J Hum Genet $\underline{68}$, 577-589

Canalis E, Pash J, Gabbitas B, Rydziel S, Varghese S (1993): Growth factors regulate the synthesis of insulin-like growth factor-I in bone cell cultures. Endocrinology $133,33-38$

Carmeliet P, Ferreira V, Breier G, Pollefeyt S, Kieckens L, Gertsenstein M, Fahrig M, Vandenhoeck A, Harpal K, Eberhardt C, et al. (1996): Abnormal blood vessel development and lethality in embryos lacking a single VEGF allele. Nature $\underline{380}$, 435-439

Carmona-Rodríguez B, Alvarez-Pérez MA, Narayanan AS, Zeichner-David M, Reyes-Gasga J, Molina-Guarneros J, García-Hernández AL, Suárez-Franco JL, Chavarría IG, Villarreal-Ramírez E, Arzate H (2007): Human Cementum Protein 1 induces expression of bone and cementum proteins by human gingival fibroblasts. Biochem Biophys Res Commun 358, 763-769

Chen D, Harris MA, Rossini G, Dunstan CR, Dallas SL, Feng JQ, Mundy GR, Harris SE (1997): Bone morphogenetic protein 2 (BMP-2) enhances BMP-3, BMP-4, and bone cell differentiation marker gene expression during the induction of mineralized bone matrix formation in cultures of fetal rat calvarial osteoblasts. Calcif Tissue Int $\underline{60}, 283-290$

Chen J, Shapiro HS, Sodek J (1992): Development expression of bone sialoprotein mRNA in rat mineralized connective tissues. J Bone Miner Res $\underline{7}$, 987-997

Cho MI, Garant PR (2000): Development and general structure of the periodontium. Periodontol $2000 \underline{24}, 9-27$

Choi H, Jin H, Kim J-Y, Lim K-T, Choung H-W, Park J-Y, Chung JH, Choung P-H (2014): Hypoxia promotes CEMP1 expression and induces cementoblastic differen- 
tiation of human dental stem cells in an HIF-1-dependent manner. Tissue Eng Part A $\underline{20}, 410-423$

Cochran DL, Wozney JM (1999): Biological mediators for periodontal regeneration. Periodontol $2000 \underline{19}, 40-58$

Cordaro L, Amadé DS, Cordaro M (2002): Clinical results of alveolar ridge augmentation with mandibular block bone grafts in partially edentulous patients prior to implant placement. Clin Oral Implants Res $\underline{13}, 103-111$

Danielson KG, Baribault H, Holmes DF, Graham H, Kadler KE, lozzo RV (1997): Targeted disruption of decorin leads to abnormal collagen fibril morphology and skin fragility. J Cell Biol $\underline{136}, 729-743$

De Fusco C, Messina A, Monda V, Viggiano E, Moscatelli F, Valenzano A, Esposito T, Sergio C, Cibelli G, Monda M, Messina G (2017): Osteopontin: Relation between Adipose Tissue and Bone Homeostasis. Stem Cells Int 2017, 4045238

Delany AM, Amling M, Priemel M, Howe C, Baron R, Canalis E (2000): Osteopenia and decreased bone formation in osteonectin-deficient mice. J Clin Invest 105, 915923

Draenert FG, Kämmerer PW, Berthold M, Neff A (2016): Complications with allogeneic, cancellous bone blocks in vertical alveolar ridge augmentation: prospective clinical case study and review of the literature. Oral Surg Oral Med Oral Pathol Oral Radiol 122, e31-43

Drenckhahn D, Christ B, Benninghoff A (Hrsg.): Zellen- und Gewebelehre, Entwicklungslehre, Skelett- und Muskelsystem, Atemsystem, Verdauungssystem, Harnund Genitalsystem. 16., völlig neu bearb. Auflage; Urban \& Fischer, München [u.a.] 2003 
Ducy P, Desbois C, Boyce B, Pinero G, Story B, Dunstan C, Smith E, Bonadio J, Goldstein S, Gundberg C, et al. (1996): Increased bone formation in osteocalcindeficient mice. Nature $\underline{382}, 448-452$

Ducy P, Zhang R, Geoffroy V, Ridall AL, Karsenty G (1997): Osf2/Cbfa1: a transcriptional activator of osteoblast differentiation. Cell $\underline{89}, 747-754$

Ducy P, Amling M, Takeda S, Priemel M, Schilling AF, Beil FT, Shen J, Vinson C, Rueger JM, Karsenty G (2000a): Leptin inhibits bone formation through a hypothalamic relay: a central control of bone mass. Cell $\underline{100}, 197-207$

Ducy P, Schinke T, Karsenty G (2000b): The osteoblast: a sophisticated fibroblast under central surveillance. Science $\underline{289}, 1501-1504$

Dudley HR, Spiro D (1961): THE FINE STRUCTURE OF BONE CELLS. J Biophys Biochem Cytol 11, 627-649

Dy P, Wang W, Bhattaram P, Wang Q, Wang L, Ballock RT, Lefebvre V (2012): Sox9 directs hypertrophic maturation and blocks osteoblast differentiation of growth plate chondrocytes. Dev Cell 22, 597-609

Eyre DR, Dickson IR, Van Ness K (1988): Collagen cross-linking in human bone and articular cartilage. Age-related changes in the content of mature hydroxypyridinium residues. Biochem J 252, 495-500

Fedarko NS, Fohr B, Robey PG, Young MF, Fisher LW (2000): Factor H binding to bone sialoprotein and osteopontin enables tumor cell evasion of complement-mediated attack. J Biol Chem $\underline{275}, 16666-16672$

Ferrara N (1999): Molecular and biological properties of vascular endothelial growth factor. J Mol Med Berl Ger 77, 527-543 
Fiedler J, Leucht F, Waltenberger J, Dehio C, Brenner RE (2005): VEGF-A and PIGF-1 stimulate chemotactic migration of human mesenchymal progenitor cells. Biochem Biophys Res Commun 334, 561-568

Fisher LW, Hawkins GR, Tuross N, Termine JD (1987): Purification and partial characterization of small proteoglycans I and II, bone sialoproteins I and II, and osteonectin from the mineral compartment of developing human bone. J Biol Chem $\underline{262}$, 9702-9708

Fisher LW, Heegaard AM, Vetter U, Vogel W, Just W, Termine JD, Young MF (1991): Human biglycan gene. Putative promoter, intron-exon junctions, and chromosomal localization. J Biol Chem 266, 14371-14377

Framson PE, Sage EH (2004): SPARC and tumor growth: where the seed meets the soil? J Cell Biochem 92, 679-690

Franz-Odendaal TA, Hall BK, Witten PE (2006): Buried alive: how osteoblasts become osteocytes. Dev Dyn Off Publ Am Assoc Anat 235, 176-190

Franzén A, Heinegård D (1985): Isolation and characterization of two sialoproteins present only in bone calcified matrix. Biochem J 232, 715-724

Fullmer HM, Sheetz JH, Narkates AJ (1974): Oxytalan connective tissue fibers: a review. J Oral Pathol $\underline{3}, 291-316$

Garant PR: Oral cells and tissues. Quintessence Pub. Co, Chicago 2003

Gasca S, Canizares J, De Santa Barbara P, Mejean C, Poulat F, Berta P, BoizetBonhoure B (2002): A nuclear export signal within the high mobility group domain regulates the nucleocytoplasmic translocation of SOX9 during sexual determination. Proc Natl Acad Sci U S A $\underline{99}, 11199-11204$ 
Gatti C, Gatti F, Chiapasco M, Esposito M (2008): Outcome of dental implants in partially edentulous patients with and without a history of periodontitis: a 5-year interim analysis of a cohort study. Eur J Oral Implantol $1,45-51$

Gerber HP, Hillan KJ, Ryan AM, Kowalski J, Keller GA, Rangell L, Wright BD, Radtke F, Aguet M, Ferrara N (1999): VEGF is required for growth and survival in neonatal mice. Dev Camb Engl 126, 1149-1159

Gubbay J, Collignon J, Koopman P, Capel B, Economou A, Münsterberg A, Vivian N, Goodfellow P, Lovell-Badge R (1990): A gene mapping to the sex-determining region of the mouse $\mathrm{Y}$ chromosome is a member of a novel family of embryonically expressed genes. Nature $\underline{346}, 245-250$

Häkkinen L, Oksala O, Salo T, Rahemtulla F, Larjava H (1993): Immunohistochemical localization of proteoglycans in human periodontium. J Histochem Cytochem 411, 1689-1699

Hamersma H, Gardner J, Beighton P (2003): The natural history of sclerosteosis. Clin Genet $\underline{63}, 192-197$

Harada SI, Balena R, Rodan GA, Rodan SB (1995): The role of prostaglandins in bone formation. Connect Tissue Res 31, 279-282

Hassell TM (1993): Tissues and cells of the periodontium. Periodontol $2000 \underline{3}$, 9-38

Hay ED (Hrsg.): Cell biology of extracellular matrix. 2. Auflage; Plenum Press, New York [u.a.] 1991

Hedbom E, Heinegård D (1989): Interaction of a 59-kDa connective tissue matrix protein with collagen I and collagen II. J Biol Chem 264, 6898-6905 
Heinemann DE, Siggelkow H, Ponce LM, Viereck V, Wiese KG, Peters JH (2000): Alkaline phosphatase expression during monocyte differentiation. Overlapping markers as a link between monocytic cells, dendritic cells, osteoclasts and osteoblasts. Immunobiology $\underline{202}$, 68-81

Hellwig E, Klimek J, Attin T: Einführung in die Zahnerhaltung: Prüfungswissen Kariologie, Endodontologie und Parodontologie ; mit 60 Tabellen. 5., überarb. und erw. Auflage,; Dt. Zahnärzte-Verlag, Köln 2010

Henthorn PS, Raducha M, Fedde KN, Lafferty MA, Whyte MP (1992): Different missense mutations at the tissue-nonspecific alkaline phosphatase gene locus in autosomal recessively inherited forms of mild and severe hypophosphatasia. Proc Natl Acad Sci U S A 89, 9924-9928

Hill PA, Reynolds JJ, Meikle MC (1995): Osteoblasts mediate insulin-like growth factor-I and -II stimulation of osteoclast formation and function. Endocrinology $\underline{136}$, 124-131

Hofbauer LC, Schoppet M (2004): Clinical implications of the osteoprotegerin /RANKL/RANK system for bone and vascular diseases. JAMA 292, 490-495

lozzo RV (1998): Matrix proteoglycans: from molecular design to cellular function. Annu Rev Biochem 67, 609-652

lozzo RV (1999): The biology of the small leucine-rich proteoglycans. Functional network of interactive proteins. J Biol Chem 274, 18843-18846

lozzo RV, Murdoch AD (1996): Proteoglycans of the extracellular environment: clues from the gene and protein side offer novel perspectives in molecular diversity and function. FASEB J Off Publ Fed Am Soc Exp Biol 10, 598-614 
Karimbux NY, Rosenblum ND, Nishimura I (1992): Site-specific expression of collagen I and XII mRNAs in the rat periodontal ligament at two developmental stages. J Dent Res $\underline{71}, 1355-1362$

Kim SW, Lu Y, Williams EA, Lai F, Lee JY, Enishi T, Balani DH, Ominsky MS, Ke HZ, Kronenberg HM, Wein MN (2017): Sclerostin Antibody Administration Converts Bone Lining Cells Into Active Osteoblasts. J Bone Miner Res $\underline{32}$, 892-901

Kingsley DM (1994): The TGF-beta superfamily: new members, new receptors, and new genetic tests of function in different organisms. Genes Dev $\underline{8}, 133-146$

Knabe C, Nicklin S, Yu Y, Walsh WR, Radlanski RJ, Marks C, Hoffmeister B (2005): Growth factor expression following clinical mandibular distraction osteogenesis in humans and its comparison with existing animal studies. J Cranio-Maxillofac Surg $\underline{33}, 361-369$

Koelling S, Kruegel J, Irmer M, Path JR, Sadowski B, Miro X, Miosge N (2009): Migratory chondrogenic progenitor cells from repair tissue during the later stages of human osteoarthritis. Cell Stem Cell $\underline{4}, 324-335$

Komaki M, Iwasaki K, Arzate H, Narayanan AS, Izumi Y, Morita I (2012): Cementum protein 1 (CEMP1) induces a cementoblastic phenotype and reduces osteoblastic differentiation in periodontal ligament cells. J Cell Physiol 227, 649-657

Komori T (2002): Runx2, a multifunctional transcription factor in skeletal development. J Cell Biochem $\underline{87}, 1-8$

Komori T (2008): Regulation of bone development and maintenance by Runx2. Front Biosci J Virtual Libr 13, 898-903

Komori T (2010): Regulation of bone development and extracellular matrix protein genes by RUNX2. Cell Tissue Res $\underline{339}, 189-195$ 
Komori T, Kishimoto T (1998): Cbfa1 in bone development. Curr Opin Genet Dev $\underline{8}$, 494-499

Komori T, Yagi H, Nomura S, Yamaguchi A, Sasaki K, Deguchi K, Shimizu Y, Bronson RT, Gao YH, Inada M, et al. (1997): Targeted disruption of Cbfa1 results in a complete lack of bone formation owing to maturational arrest of osteoblasts. Cell $\underline{89}$, $755-764$

Kondaiah P, Sands MJ, Smith JM, Fields A, Roberts AB, Sporn MB, Melton DA (1990): Identification of a novel transforming growth factor-beta (TGF-beta 5) mRNA in Xenopus laevis. J Biol Chem 265, 1089-1093

Kribbs PJ (1990): Comparison of mandibular bone in normal and osteoporotic women. J Prosthet Dent $\underline{63}$, 218-222

Kribbs PJ, Chesnut CH, Ott SM, Kilcoyne RF (1989): Relationships between mandibular and skeletal bone in an osteoporotic population. J Prosthet Dent $\underline{62}, 703-$ 707

Kurihara S, Enlow DH (1980): An electron microscopic study of attachments between periodontal fibers and bone during alveolar remodeling. Am $\mathrm{J}$ Orthod $\underline{77}$, $516-531$

Lamour V, Detry C, Sanchez C, Henrotin Y, Castronovo V, Bellahcène A (2007): Runx2- and histone deacetylase 3-mediated repression is relieved in differentiating human osteoblast cells to allow high bone sialoprotein expression. J Biol Chem $\underline{282}$, 36240-36249

Landis WJ (1995): The strength of a calcified tissue depends in part on the molecular structure and organization of its constituent mineral crystals in their organic matrix. Bone $\underline{16}$, 533-544 
Lane TF, Sage EH (1994): The biology of SPARC, a protein that modulates cellmatrix interactions. FASEB J Off Publ Fed Am Soc Exp Biol $\underline{8}$, 163-173

Laudet V, Stehelin D, Clevers H (1993): Ancestry and diversity of the HMG box superfamily. Nucleic Acids Res 21, 2493-2501

Li QL, Ito K, Sakakura C, Fukamachi H, Inoue K ichi, Chi XZ, Lee KY, Nomura S, Lee CW, Han SB, et al. (2002): Causal relationship between the loss of RUNX3 expression and gastric cancer. Cell $\underline{109}, 113-124$

Long MW, Robinson JA, Ashcraft EA, Mann KG (1995): Regulation of human bone marrow-derived osteoprogenitor cells by osteogenic growth factors. J Clin Invest $\underline{95}$, $881-887$

Lukinmaa PL, Waltimo J (1992): Immunohistochemical localization of types I, V, and $\mathrm{VI}$ collagen in human permanent teeth and periodontal ligament. J Dent Res $\underline{71}$, 391-397

Malaval L, Wade-Guéye NM, Boudiffa M, Fei J, Zirngibl R, Chen F, Laroche N, Roux J-P, Burt-Pichat B, Duboeuf F, et al. (2008): Bone sialoprotein plays a functional role in bone formation and osteoclastogenesis. J Exp Med 205, 1145-1153

Manolagas SC (2000): Birth and death of bone cells: basic regulatory mechanisms and implications for the pathogenesis and treatment of osteoporosis. Endocr Rev $\underline{21}, 115-137$

Massagué J (1990): The transforming growth factor-beta family. Annu Rev Cell Biol $\underline{6}, 597-641$

Matthews BG, Roguljic H, Franceschetti T, Roeder E, Matic I, Vidovic I, Joshi P, Kum K-Y, Kalajzic I (2016): Gene-expression analysis of cementoblasts and osteoblasts. J Periodontal Res $\underline{51}$, 304-312 
Mayr-Wohlfart U, Waltenberger J, Hausser H, Kessler S, Günther K-P, Dehio C, Puhl W, Brenner RE (2002): Vascular endothelial growth factor stimulates chemotactic migration of primary human osteoblasts. Bone $\underline{30}, 472-477$

McVey JH, Nomura S, Kelly P, Mason IJ, Hogan BL (1988): Characterization of the mouse SPARC/osteonectin gene. Intron/exon organization and an unusual promoter region. J Biol Chem $\underline{263}, 11111-11116$

Miller SC, Jee WS (1987): The bone lining cell: a distinct phenotype? Calcif Tissue Int $\underline{41}, 1-5$

Miyazaki T, Kanatani N, Rokutanda S, Yoshida C, Toyosawa S, Nakamura R, Takada S, Komori T (2008): Inhibition of the terminal differentiation of odontoblasts and their transdifferentiation into osteoblasts in Runx2 transgenic mice. Arch Histol Cytol $\underline{71}, 131-146$

Mundlos S, Otto F, Mundlos C, Mulliken JB, Aylsworth AS, Albright S, Lindhout D, Cole WG, Henn W, Knoll JH, et al. (1997): Mutations involving the transcription factor CBFA1 cause cleidocranial dysplasia. Cell $\underline{89}$, 773-779

Nanci A, Bosshardt DD (2006): Structure of periodontal tissues in health and disease. Periodontol $2000 \underline{40}, 11-28$

Neufeld G, Cohen T, Gengrinovitch S, Poltorak Z (1999): Vascular endothelial growth factor (VEGF) and its receptors. FASEB J Off Publ Fed Am Soc Exp Biol $\underline{13}$, 9-22

Neve A, Corrado A, Cantatore FP (2013): Osteocalcin: skeletal and extra-skeletal effects. J Cell Physiol 228, 1149-1153

Ng LJ, Wheatley S, Muscat GE, Conway-Campbell J, Bowles J, Wright E, Bell DM, Tam PP, Cheah KS, Koopman P (1997): SOX9 binds DNA, activates transcription, 
and coexpresses with type II collagen during chondrogenesis in the mouse. Dev Biol $\underline{183}, 108-121$

Ogawa E, Maruyama M, Kagoshima H, Inuzuka M, Lu J, Satake M, Shigesada K, Ito $Y$ (1993): PEBP2/PEA2 represents a family of transcription factors homologous to the products of the Drosophila runt gene and the human AML1 gene. Proc Natl Acad Sci U S A $\underline{90}, 6859-6863$

Orban B (1948): Clinical and histologic study of the surface characteristics of the gingiva. Oral Surg Oral Med Oral Pathol 1, 827-841

Owen M (1980): The origin of bone cells in the postnatal organism. Arthritis Rheum $\underline{23}, 1073-1080$

Paic F, Igwe JC, Nori R, Kronenberg MS, Franceschetti T, Harrington P, Kuo L, Shin D-G, Rowe DW, Harris SE, Kalajzic I (2009): Identification of differentially expressed genes between osteoblasts and osteocytes. Bone $\underline{45}, 682-692$

Pierce AM, Lindskog S, Hammarström L (1991): Osteoclasts: structure and function. Electron Microsc Rev $\underline{4}, 1-45$

Pihlstrom BL, Buse JB (2014): Diabetes and periodontal therapy. J Am Dent Assoc $\underline{145}, 1208-1210$

Pihlstrom BL, Michalowicz BS, Johnson NW (2005): Periodontal diseases. Lancet Lond Engl 366, 1809-1820

Pinero GJ, Farach-Carson MC, Devoll RE, Aubin JE, Brunn JC, Butler WT (1995): Bone matrix proteins in osteogenesis and remodelling in the neonatal rat mandible as studied by immunolocalization of osteopontin, bone sialoprotein, alpha 2HS-glycoprotein and alkaline phosphatase. Arch Oral Biol 40, 145-155 
Poole KES, van Bezooijen RL, Loveridge N, Hamersma H, Papapoulos SE, Löwik CW, Reeve J (2005): Sclerostin is a delayed secreted product of osteocytes that inhibits bone formation. FASEB J Off Publ Fed Am Soc Exp Biol 19, 1842-1844

Price PA, Williamson MK (1981): Effects of warfarin on bone. Studies on the vitamin K-dependent protein of rat bone. J Biol Chem 256, 12754-12759

Quelch KJ, Melick RA, Bingham PJ, Mercuri SM (1983): Chemical composition of human bone. Arch Oral Biol 28, 665-674

Radlanski RJ: Orale Struktur- und Entwicklungsbiologie: (Curriculum); QuintessenzVerlag, Berlin [u.a.] 2011

Rao LG, Wang HM, Kalliecharan R, Heersche JN, Sodek J (1979): Specific immunohistochemical localization of type I collagen in porcine periodontal tissues using the peroxidase-labelled antibody technique. Histochem J 11, 73-82

Raynal C, Delmas PD, Chenu C (1996): Bone sialoprotein stimulates in vitro bone resorption. Endocrinology 137, 2347-2354

Reddi AH (1998): Role of morphogenetic proteins in skeletal tissue engineering and regeneration. Nat Biotechnol $\underline{16}, 247-252$

Rittling SR, Matsumoto HN, McKee MD, Nanci A, An XR, Novick KE, Kowalski AJ, Noda M, Denhardt DT (1998): Mice lacking osteopontin show normal development and bone structure but display altered osteoclast formation in vitro. J Bone Miner $\operatorname{Res} \underline{13}, 1101-1111$

Roach HI (1994): Why does bone matrix contain non-collagenous proteins? The possible roles of osteocalcin, osteonectin, osteopontin and bone sialoprotein in bone mineralisation and resorption. Cell Biol Int $\underline{18}, 617-628$ 
Robertson BW, Chellaiah MA (2010): Osteopontin induces beta-catenin signaling through activation of Akt in prostate cancer cells. Exp Cell Res $\underline{316}, 1-11$

Robling AG, Niziolek PJ, Baldridge LA, Condon KW, Allen MR, Alam I, Mantila SM, Gluhak-Heinrich J, Bellido TM, Harris SE, Turner CH (2008): Mechanical stimulation of bone in vivo reduces osteocyte expression of Sost/sclerostin. J Biol Chem $\underline{283}$, $5866-5875$

Rodan GA, Heath JK, Yoon K, Noda M, Rodan SB (1988): Diversity of the osteoblastic phenotype. Ciba Found Symp $\underline{136}$, 78-91

Rosen V, Wozney JM, Wang EA, Cordes P, Celeste A, McQuaid D, Kurtzberg L (1989): Purification and molecular cloning of a novel group of BMPs and localization of BMP mRNA in developing bone. Connect Tissue Res 20, 313-319

Ruoslahti E (1988): Structure and biology of proteoglycans. Annu Rev Cell Biol $\underline{4}$, 229-255

Saffar JL, Lasfargues JJ, Cherruau M (1997): Alveolar bone and the alveolar process: the socket that is never stable. Periodontol $2000 \underline{13}, 76-90$

Schroeder HE: The periodontium. Springer, Berlin [u.a.] 1986

Seipel CM (1948): Trajectories of the jaws. Acta Odontol Scand $\underline{8}, 81-191$

Sodek J, McKee MD (2000): Molecular and cellular biology of alveolar bone. Periodontol $2000 \underline{24}, 99-126$

Sodek J, Chen J, Nagata T, Kasugai S, Todescan R, Li IW, Kim RH (1995): Regulation of osteopontin expression in osteoblasts. Ann N Y Acad Sci $\underline{760}, 223-241$ 
Sodek J, Ganss B, McKee MD (2000): Osteopontin. Crit Rev Oral Biol Med 11, 279_ 303

Südbeck P, Scherer G (1997): Two independent nuclear localization signals are present in the DNA-binding high-mobility group domains of SRY and SOX9. J Biol Chem $\underline{272}, 27848-27852$

Teeuw WJ, Kosho MXF, Poland DCW, Gerdes VEA, Loos BG (2017): Periodontitis as a possible early sign of diabetes mellitus. BMJ Open Diabetes Res Care $\underline{5}$, e000326

Ten Cate AR, Mills C (1972): The development of the periodontium: the origin of alveolar bone. Anat Rec $\underline{173}, 69-77$

Terai K, Takano-Yamamoto T, Ohba Y, Hiura K, Sugimoto M, Sato M, Kawahata H, Inaguma N, Kitamura Y, Nomura S (1999): Role of osteopontin in bone remodeling caused by mechanical stress. J Bone Miner Res $\underline{14}$, 839-849

Termine JD, Kleinman HK, Whitson SW, Conn KM, McGarvey ML, Martin GR (1981): Osteonectin, a bone-specific protein linking mineral to collagen. Cell $\underline{26}$, 99105

Thieszen SL, Rosenquist TH (1995): Expression of collagens and decorin during aortic arch artery development: implications for matrix pattern formation. Matrix Biol J $\underline{14}, 573-582$

Trask BC, Trask TM, Broekelmann T, Mecham RP (2000): The microfibrillar proteins MAGP-1 and fibrillin-1 form a ternary complex with the chondroitin sulfate proteoglycan decorin. Mol Biol Cell 11, 1499-1507 
Trombetta JM, Bradshaw AD (2010): SPARC/osteonectin functions to maintain homeostasis of the collagenous extracellular matrix in the periodontal ligament. J Histochem Cytochem 묘, 871-879

Urban IA, Nagursky H, Lozada JL, Nagy K (2013): Horizontal ridge augmentation with a collagen membrane and a combination of particulated autogenous bone and anorganic bovine bone-derived mineral: a prospective case series in 25 patients. Int J Periodontics Restorative Dent $\underline{33}$, 299-307

Van Hoof VO, De Broe ME (1994): Interpretation and clinical significance of alkaline phosphatase isoenzyme patterns. Crit Rev Clin Lab Sci 31, 197-293

Vogel KG, Trotter JA (1987): The effect of proteoglycans on the morphology of collagen fibrils formed in vitro. Coll Relat Res $\underline{7}, 105-114$

Vogel KG, Paulsson M, Heinegård D (1984): Specific inhibition of type I and type II collagen fibrillogenesis by the small proteoglycan of tendon. Biochem $\mathrm{J} \underline{223}, 587-$ 597

Wang H, Mao Y, Zhang B, Wang T, Li F, Fu S, Xue Y, Yang T, Wen X, Ding Y, Duan X (2010): Chloride channel CIC-3 promotion of osteogenic differentiation through Runx2. J Cell Biochem 111, 49-58

Wang HM, Nanda V, Rao LG, Melcher AH, Heersche JN, Sodek J (1980): Specific immunohistochemical localization of type III collagen in porcine periodontal tissues using the peroxidase-antiperoxidase method. J Histochem Cytochem $\underline{28}, 1215-$ 1223

Wegner M (1999): From head to toes: the multiple facets of Sox proteins. Nucleic Acids Res 27, 1409-1420 
Wennberg C, Hessle L, Lundberg P, Mauro S, Narisawa S, Lerner UH, Millán JL (2000): Functional characterization of osteoblasts and osteoclasts from alkaline phosphatase knockout mice. J Bone Miner Res Off J Am Soc Bone Miner Res $\underline{15}$, 1879-1888

Wolf G (1996): Function of the bone protein osteocalcin: definitive evidence. Nutr $\operatorname{Rev} \underline{54}, 332-333$

Wozney JM, Rosen V, Celeste AJ, Mitsock LM, Whitters MJ, Kriz RW, Hewick RM, Wang EA (1988): Novel regulators of bone formation: molecular clones and activities. Science $\underline{242}, 1528-1534$

Ylä-Herttuala S, Rissanen TT, Vajanto I, Hartikainen J (2007): Vascular endothelial growth factors: biology and current status of clinical applications in cardiovascular medicine. J Am Coll Cardiol 49, 1015-1026

Young MF, Kerr JM, Ibaraki K, Heegaard AM, Robey PG (1992): Structure, expression, and regulation of the major noncollagenous matrix proteins of bone. Clin Orthop 275-294

Zernik J, Twarog K, Upholt WB (1990): Regulation of alkaline phosphatase and alpha 2(I) procollagen synthesis during early intramembranous bone formation in the rat mandible. Differ Res Biol Divers $\underline{44}, 207-215$

Zhang R, Ducy P, Karsenty G (1997): 1,25-dihydroxyvitamin D3 inhibits Osteocalcin expression in mouse through an indirect mechanism. J Biol Chem 272, 110-116

Zhao Q, Eberspaecher H, Lefebvre V, De Crombrugghe B (1997): Parallel expression of Sox9 and Col2a1 in cells undergoing chondrogenesis. 209, 377-38 
Zung P, Domenicucci C, Wasi S, Kuwata F, Sodek J (1986): Osteonectin is a minor component of mineralized connective tissues in rat. Biochem Cell Biol Biochim Biol Cell $\underline{64}, 356-362$ 


\section{Danksagung}

Mein besonderer Dank gilt Herrn Prof. Dr. Nicolai Miosge, der mir das Schreiben meiner Dissertation überhaupt ermöglichte und mir durch die Aufnahme in seine Arbeitsgruppe einen völlig neuen Einblick in den Arbeitsalltag einer wissenschaftlichen Forschungsgruppe gewährte. Diesen gestaltete er durch seine bemerkenswerte wissenschaftliche Unterstützung und Betreuung stets angenehm.

Außerdem möchte ich Frau Christa Bode für ihre kompetente Einführung in die verschiedenen biochemischen Methoden und ihre Unterstützung bei deren Durchführung danken, wodurch stets ein reibungsloser Ablauf gewährleistet war. Weiterhin möchte ich Herrn Jérôme Janßen für seine unglaubliche Geduld und Hilfsbereitschaft während der Forschungsarbeiten danken, wodurch ein schnelles Arbeiten stets möglich war und es immer ein angenehmes Arbeitsklima gab.

Herrn Gökhan Cingöz gilt mein Dank für die kompetente Hilfe bei technischen Fragestellungen und Frau Dr. med. dent. Andrea Schubert, Herrn Stefan Lesemann sowie Herrn Dr. med. dent. Boris Schminke für ihre große Diskussions- und Hilfsbereitschaft.

Außerdem möchte ich meiner Mitdoktorandin Katharina Bernhardt danken, ohne die ich meine Dissertation wahrscheinlich gar nicht begonnen hätte. Dank ihrer Hilfe war ein schnelles sowie motiviertes Arbeiten möglich, und es herrschte stets eine freundschaftliche Atmosphäre. 


\section{Lebenslauf}

Am 13.02.1991 wurde ich als einziges gemeinsames Kind meiner Eltern Brigitte Dillschneider, geborene Schwienheer, und Karl Manfred Dillschneider in Saarlouis geboren. Meine Mutter ist Hausfrau und mein Vater ist als selbstständiger Rechtsanwalt tätig.

Die Grundschule Schwemlingen besuchte ich von 1997 bis 2001. Anschließend trat ich auf das Gymnasium am Stefansberg in Merzig über, wo ich 2009 mein Abitur ablegte. Im Sommer 2010 begann ich eine Berufsausbildung zur zahnmedizinischen Fachangestellten in der Zahnarztpraxis Abend in Mainz.

Im Wintersemester 10/11 begann ich mit dem Studium der Zahnheilkunde an der Universität in Göttingen. Die naturwissenschaftliche Vorprüfung bestand ich im September 2011, das Physikum im März 2013. Das zahnmedizinische Staatsexamen absolvierte ich im Juni 2016. Im Juli 2016 begann ich daraufhin mit meiner Dissertation im Fach Zahnmedizin in der Arbeitsgruppe orale Biologie und Geweberegeneration, an der Medizinischen Fakultät Göttingen unter der Betreuung von Prof. Dr. med. Nicolai Miosge. 